\title{
MAPEAMENTO DE RISCO DE ESCORREGAMENTO NA REGIÃO DE CUBATÃO, SP
}

\author{
MARCO AURÉLIO NALON \\ Físico \\ Orientador: Prof. Dr. HILTON THADEU ZARATE DO COUTO
}

Dissertação apresentada à Escola Superior de Agricultura "Luiz de Queiroz", Universidade de São Paulo, para obtenção do título de Mestre em Ciências, Área de Concentração: Ciências Florestais.

\author{
PIRACICABA \\ Estado de São Paulo - Brasil
}

Fevereiro - 2000 


\section{ERRATA}

\begin{tabular}{|c|c|c|c|}
\hline Página & Linha & Onde se lê & Leia-se \\
\hline 5 & 9 & "...de todas os fatores..." & "...de todos os fatores ..." \\
\hline 29 & 12 & ...com menos de $0,40 \mathrm{~cm} . . . "$ & ...com menos de $0,40 \mathrm{~m} . . . "$ \\
\hline 33 & 26 & "“..TURRINI (1998)..." & $\begin{array}{l}\text { "...TURRINI \& } \\
(1998) \ldots .\end{array}$ \\
\hline 40 & 22 & "...os error médios..." & "...os erros médios..." \\
\hline 38 & 10 & & \\
\hline 67 & 17 & "...um distribuição normal..." & "...uma distribuição normal..." \\
\hline 83 & 3 & "...podem se considerados..." & "...podem ser considerados..." \\
\hline
\end{tabular}



DIVISÄO DE BIBLIOTECA E dOCUMENTAÇÃo- - Campus "Luiz ḋe Queiroz"/USP

\author{
Nalon, Marco Aurélio \\ Mapeamento de risco de escorregamento na região de Cubatžo, SP / Marco
}

Aurélio Nalon. - - Piracicaba, 2000.

$147 \mathrm{p}$. : il.

Dissertação (mestrado) - - Escola Superior de Agricultura Luiz de Queiroz, 2000. Bibliografia.

1. Análise multivariada 2. Análise de risco 3. Geoprocessamento 4. Manejo ambiental 5. Mapeamento digital 6. Proteção ambiental 7. Serra do mar 8. SIC I. Título

CDD 333.72 
Dedicatória

Dedico esse estudo científico à humanidade, de cujo conhecimento é fruto e do qual agora passa fazer parte. 


\section{AGRADECIMENTOS}

Agradeço ao meu orientador, Prof. Dr. Hilton Thadeu Zarate do

Couto, pela confiança que depositou em meu trabalho, e por ter estado sempre presente quando necessário.

Agradeço a colaboração dos colegas do Instituto Florestal, Marina Mitsue Kanashiro, na preparação do material cartográfico, e de Maria Shizue Shin-lke, no apoio nos bancos de dados.

Ao Prof. Dr. Ardemírio de Barros Silva, do Instituto de Geociências da UNICAMP, por todo apoio dado durante a execução desse trabalho.

Ao PqC. Francisco José do Nascimento Kronka, do Instituto Florestal, pelo companheirismo, pela confiança e pelo apoio ao longo de todos esses anos.

A CAPES e a FAPESP, pelas bolsas de estudo cedidas ao longo da execução desse trabalho. 
SUMÁRIO

Página

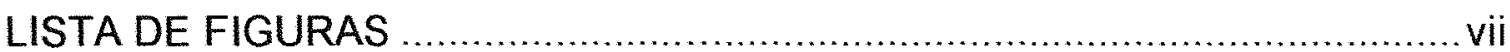

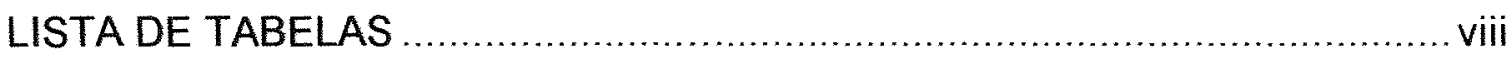

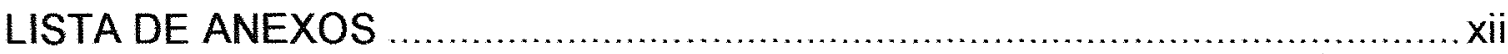

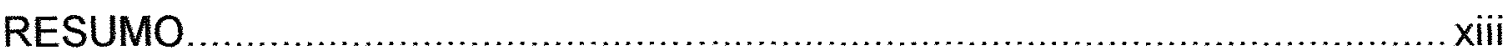

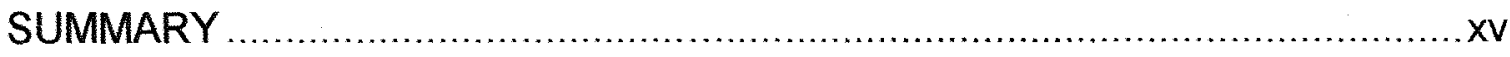

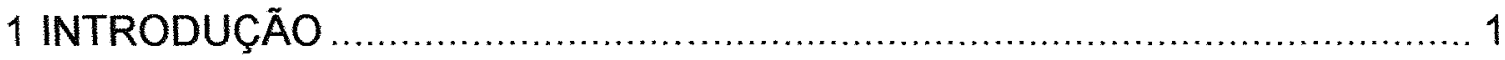

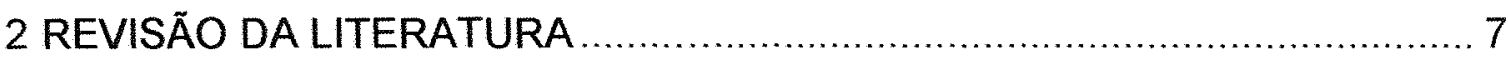

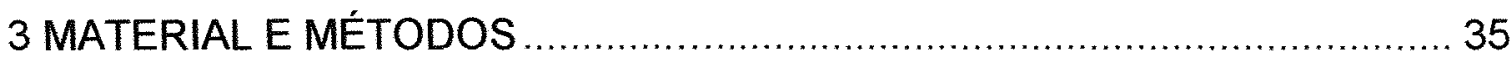

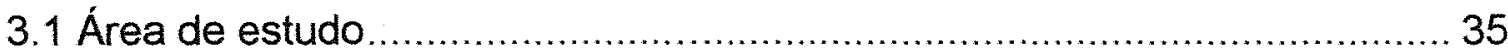

3.2 Tecnologia de sistema de informações geográficas (SIG) .................... 37

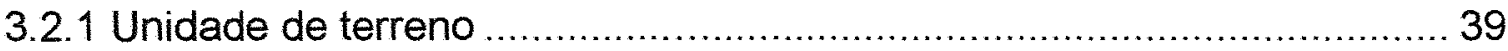

3.2.2 Conversão de dados do formato analógico para formato digital ........... 40

3.2.3 Tipos de arquivos para uso em SIG................................................ 41

3.2.4 Construção de topologia dos arquivos vetoriais para uso em SIG ......... 41

3.2.5 Arquivos raster baseados em modelos numéricos .............................. 44

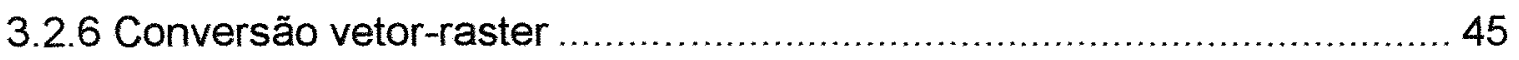

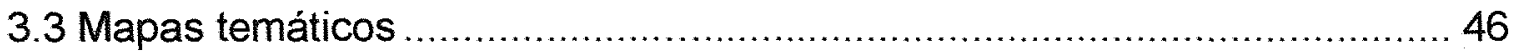

3.3.1 Modelo digital de terreno (MDT) e seus produtos ............................. 46

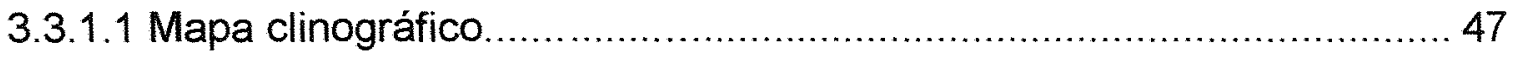

3.3.1.2 Mapa de exposição de vertentes............................................... 48

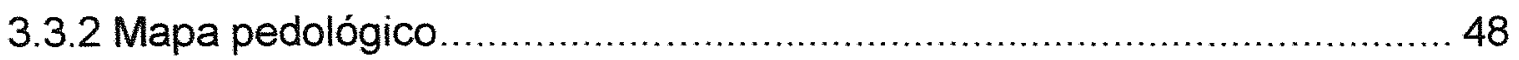

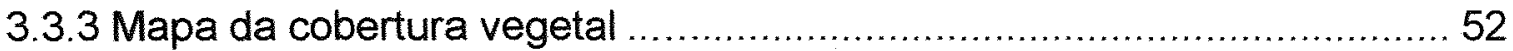

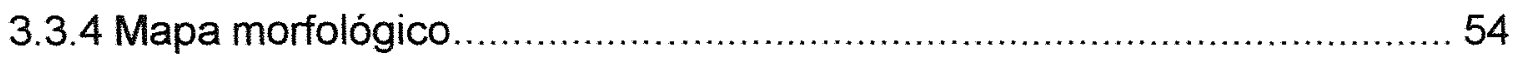

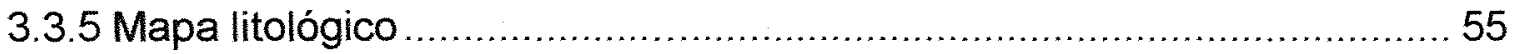

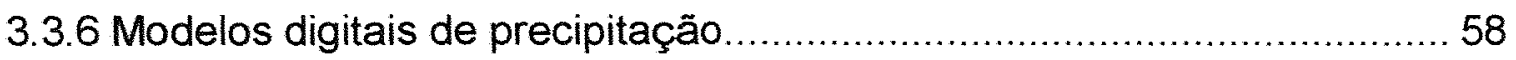

3.3.7 Mapa das áreas com escorregamento ...................................... 59

3.3.8 Mapa das áreas sem escorregamento ....................................... 59 
3.4 Atributos associados aos mapas temáticos 60

3.5 Modelo multivariado de análise discriminante para avaliação do risco de

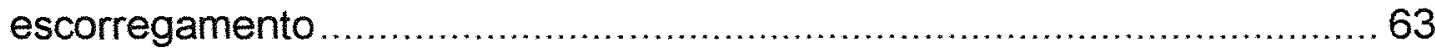

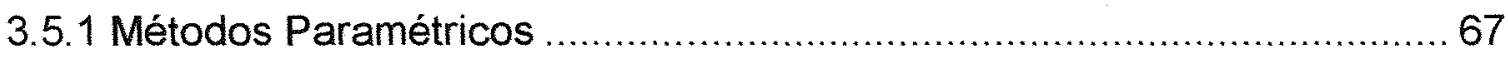

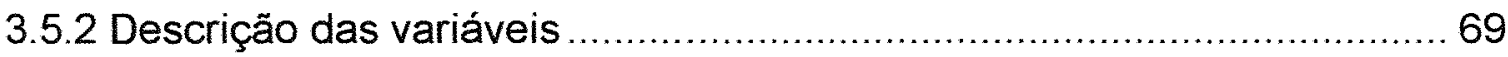

3.5.3 Geração de tabelas para análise discriminante .................................... 70

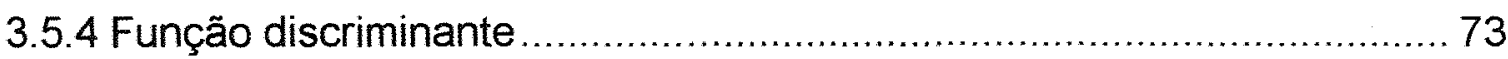

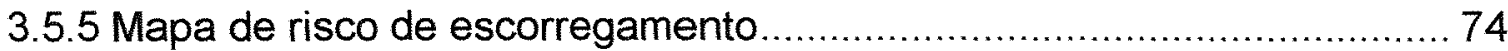

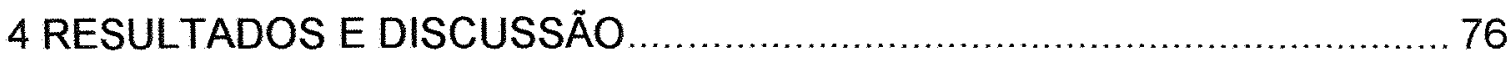

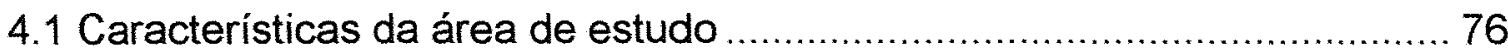

4.2 Características das áreas com escorregamento .................................... 84

4.3 Características das áreas sem escorregamento ................................... 93

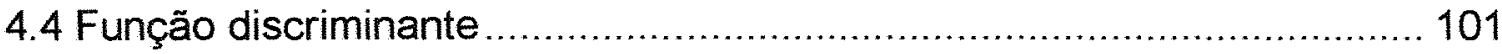

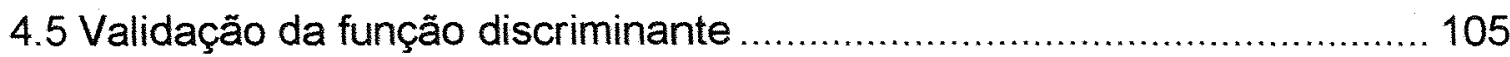

4.6 Mapa de risco de escorregamento..................................................... 106

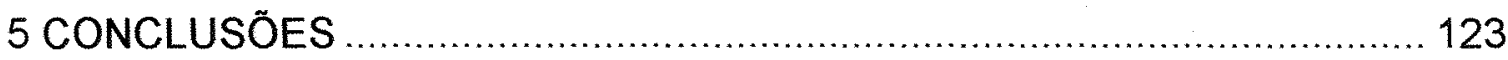

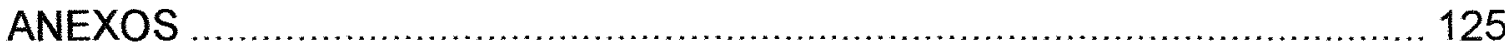

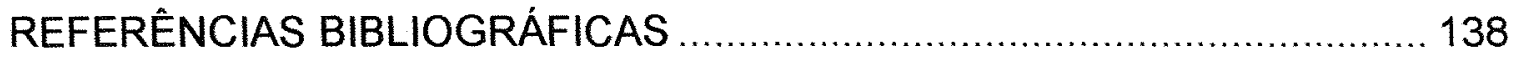




\section{LISTA DE FIGURAS}

Página

1 Precipitação média total mensal registrada no período entre 1969 e 1986 no posto pluviométrico E3-101 Cubatão, do D.A.E.E. (Departamento de Águas e Energia Elétrica). ........................................ 5

2 Mapa de localização da área de estudo. ................................................ 36 


\section{LISTA DE TABELAS}

Página

1 Eventos desastrosos de movimento de massa ocorridos durante a estação chuvosa de novembro a abril ............................................. 2

2 Grau de incerteza de alguns fatores de instabilidade .............................. 24

3 PAT (Polygon Attribute Table ou Tabela de Atributos de Poligonos)........ 43

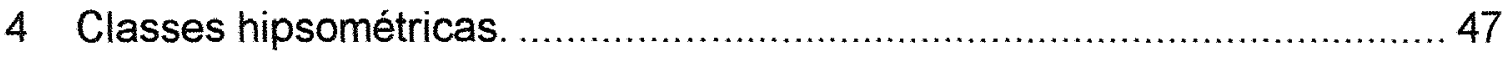

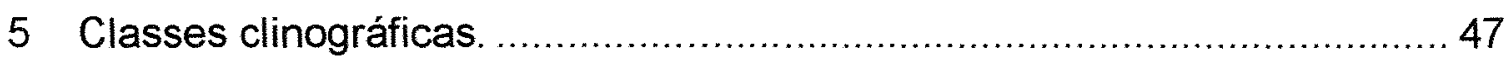

6 Classes de exposição de vertentes. ..................................................... 48

7 Classes pedológicas da carta de reconhecimento dos solos do Parque Estadual da Serra do Mar, ROSSI \& PFEIFER (1991) ............................. 49

8 Classes de vegetação do mapa de cobertura vegetal do Parque Estadual da Serra do Mar, MATTOS \& MATSUKUMA (1990)................... 53

9 Unidades geomorfológicas, CETESB (1991) ...................................... 54

10 Classes litológicas, CETESB (1991) ................................................... 55

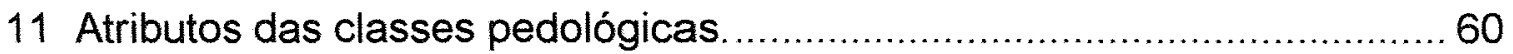

12 Atributos das classes de cobertura vegetal. ........................................ 61

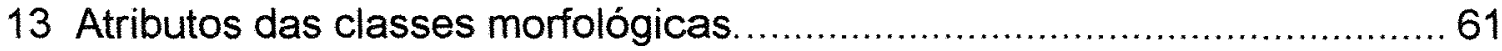

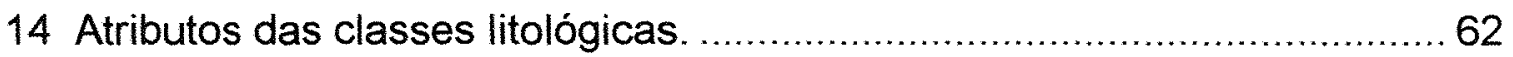

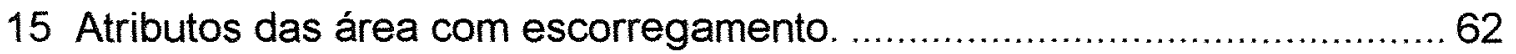

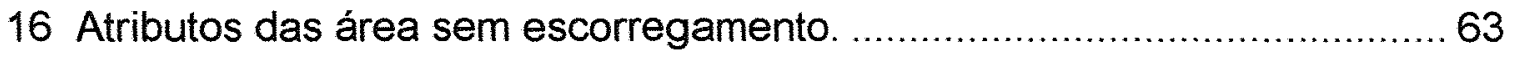

17 Tabela de dados para aplicação da análise discriminante. …...................73

18 Fatores de instabilidade para cada unidade de terreno da

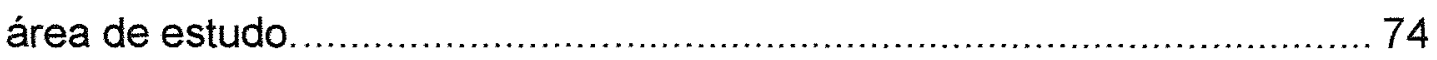

19 Probabilidade das unidades de terreno serem ou

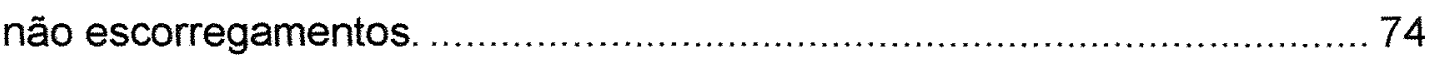

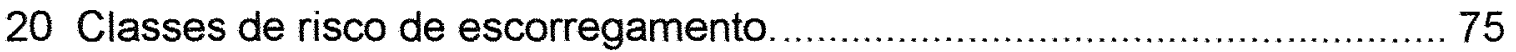

21 Ocorrência das classes hipsométricas na área de estudo ...................... 77

22 Ocorrência das classes clinográficas na área de estudo....................... 77 
23 Ocorrência das classes de exposição de vertentes na área de estudo. 78

24 Ocorrência das classes pedológicas na área de estudo. ...................... 79

25 Ocorrência das classes de cobertura vegetal na área de estudo............. 80

26 Ocorrência das classes morfológicas na área de estudo. ....................... 81

27 Ocorrência das classes litológicas na área de estudo ........................... 81

28 Ocorrência das classes de média de precipitação do trimestre mais chuvoso na área de estudo.

29 Ocorrência das classes de média de precipitação total anual na área de estudo.

30 Ocorrência das classes de superfície nas áreas com escorregamento.

31 Ocorrência das classes hipsométricas nas áreas com escorregamento.

32 Ocorrência das classes clinográficas nas áreas com escorregamento.

33 Ocorrência das classes de exposição de vertentes nas áreas com escorregamento.

34 Ocorrência das classes pedológicas nas áreas

com escorregamento.

35 Ocorrência das classes de cobertura vegetal nas áreas

com escorregamento.

36 Ocorrência das classes morfológicas nas áreas com escorregamento.

37 Ocorrência das classes litológicas nas áreas com escorregamento.

38 Ocorrência das classes de precipitação média do trimestre mais chuvoso nas áreas com escorregamento. 91

39 Ocorrência das classes de precipitação média total anual 


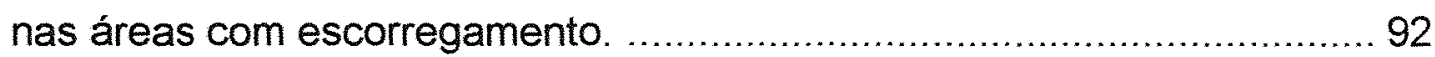

40 Ocorrência das classes hipsométricas nas áreas

sem escorregamento.

94

41 Ocorrência das classes clinográficas nas áreas

sem escorregamento.

94

42 Ocorrência das classes de exposição e vertentes nas áreas

sem escorregamento.

43 Ocorrência das classes pedológicas nas áreas

sem escorregamento.

44 Ocorrência das classes de cobertura vegetal nas áreas

sem escorregamento.

45 Ocorrência das classes morfológicas nas áreas

sem escorregamento.

46 Ocorrência das classes litológicas nas áreas sem escorregamento

47 Ocorrência das classes de precipitação média do trimestre mais chuvoso nas áreas sem escorregamento.

48 Ocorrência das classes de precipitação média total anual nas áreas sem escorregamento. 100

49 Freqüências, pesos, proporções e probabilidades prévias dos grupos analisados 101

50 Valores dos coeficientes da função discriminante para áreas com e sem escorregamento. 103

51 Número e a taxa de áreas corretamente reclassificadas por grupo e no geral pela função discriminante. 104

52 Taxa de erro da classificação da pela função discriminante por grupo e no geral. 105

53 Número e a taxa de áreas corretamente classificadas por grupo e no geral pela função discriminante. 
54 Taxa de erro da classificação da pela função discriminante

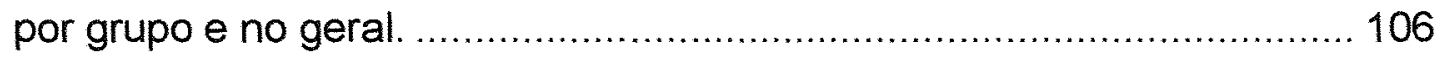

55 Distribuição da superfície do mapa de risco de escorregamento da área de estudo em função de suas classes...................................... 107

56 Valores de Z máximo, mínimo e médio para áreas com escorregamento, sem escorregamento e não classificadas.

57 Coincidência das classes de risco de escorregamento com as classes hipsométricas.

58 Coincidência das classes de risco de escorregamento com as classes clinométricas.

59 Coincidência das classes de risco de escorregamento com as classes de exposição de vertentes.

60 Coincidência das classes de risco de escorregamento com as classes pedológicas

61 Coincidência das classes de risco de escorregamento com as classes de cobertura vegetal.

62 Coincidência das classes de risco de escorregamento com as classes morfológicas.

63 Coincidência das classes de risco de escorregamento com as classes litológicas.

64 Coincidência das classes de risco de escorregamento com as classes de precipitação média do trimestre mais chuvoso. 116

65 Coincidência das classes de risco de escorregamento com as classes de precipitação média total anual.

66 Fatores de instabilidade predominantes nas áreas classificadas com risco de escorregamento muito baixo e muito alto, na área de estudo, nas áreas com escorregamento e nas áreas sem escorregamento.

67 Classes predominantes dos fatores de instabilidade por classe de risco de escorregamento. 


\section{LISTA DE ANEXOS}

Página

A Mapa Hipsométrico da Região de Cubatão, SP …................................ 126

B Mapa Clinográfico da Região de Cubatão, SP ...................................... 127

C Mapa de Exposição de Vertentes da Região de Cubatão, SP ................... 128

D Mapa Pedológico da Região de Cubatão, SP

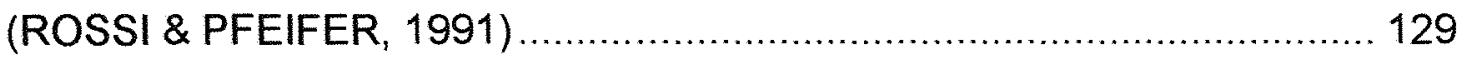

E Mapa da Cobertura Vegetal da Região de Cubatão, SP

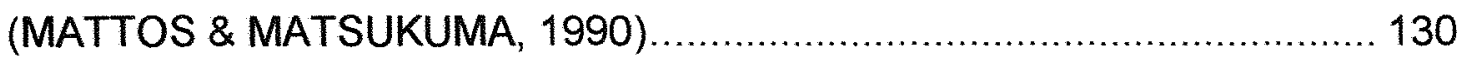

F Mapa Morfológico da Região de Cubatão, SP (CETESB, 1991) ............... 131

G Mapa Litológico da Região de Cubatão, SP (CETESB, 1991) .................. 132

H Mapa da Precipitação Média do Trimestre mais Chuvoso da Região de Cubatão, SP (IPT, 1985) ................................................. 133

I Mapa da Precipitação Média Total Anual da Região de Cubatão, SP (IPT, 1985)

$J$ Mapa das Áreas com Escorregamento da Região de Cubatão, SP (CETESB, 1991) ......................................... 135

K Mapa das Áreas sem Escorregamento da Região de Cubatão, SP .......... 136

L Mapa de Risco de Escorregamento da Região de Cubatão, SP ............... 137 


\title{
MAPEAMENTO DE RISCO DE ESCORREGAMENTO NA REGIÃO DE CUBATÃO, SP
}

\author{
Autor: MARCO AURÉLIO NALON \\ Orientador: Prof. Dr. HILTON THADEU ZARATE DO COUTO
}

\section{RESUMO}

A Serra do Mar, na região de Cubatão, é uma área de contraste entre a conservação do meio ambiente e a ocupação do homem. Nessa região têm ocorrido movimentos de massa cujas causas podem ser naturais, porém são intensificados pela ação antrópica. A presença de rodovias, oleodutos, indústrias, centro habitacionais e outras estruturas na região, faz com que esses processos erosivos possam ter conseqüências trágicas, principalmente para a população e ao meio ambiente. No sentido de contribuir para a prevenção desses eventos, este estudo teve como objetivo o mapeamento do risco de escorregamentos, a partir de mapas temáticos de cobertura vegetal, pedologia, litologia, morfologia, hipsometria, clinografia, exposição de vertentes e da precipitação pluviométrica, considerados fatores de instabilidade. Utilizouse como ferramentas um Sistema de Informações Geográficas (SIG), e um modelo estatístico multivariado, a análise discriminante. A área estudada compreendeu uma superfície de $10.706,9$ ha, onde estão contidos os vales do 
rio Mogi, rio Perequê, parte do rio Pilões e parte do rio Cubatão. Esta foi dividida em unidades de terreno em forma de grade de células de $30 \mathrm{~m} \times 30 \mathrm{~m}$. Os mapas temáticos foram convertidos para o formato digital raster. Áreas com escorregamento e sem escorregamento, foram amostradas quanto as suas características hipsométricas, clinográficas, de exposição de vertentes, pluviométricas, pedológicas, de cobertura vegetal, morfológicas e litológicas, considerados fatores de instabilidade. Esses dados foram submetidos à análise discriminante, a partir da qual foi gerada uma função linear discriminante, onde foram atribuídos pesos a cada fator de instabilidade, proporcionais a contribuição de cada um na ocorrência ou não de escorregamentos. A partir desta função foi calculada a probabilidade posterior de uma área ser ou não um escorregamento, considerada o risco. Uma amostra de validação mostrou sua eficiência na classificação de áreas como sendo com escorregamento e sem escorregamento, em $82,41 \%$ da mesma. Sua aplicação em cada unidade de terreno da área de estudo gerou um mapa de risco de escorregamentos em cinco níveis: muito baixo $(44,4 \%)$, baixo $(10,2 \%)$, médio $(9,3 \%)$, alto $(12,9 \%)$ e muito alto $(12,7 \%)$. Os maiores pesos na função discriminante foram atribuídos à clinografia, precipitação média do trimestre mais chuvoso, pedologia e litologia. Áreas com risco de escorregamento alto e muito alto que ocorreram em vertentes da média e alta encosta ( $300 \mathrm{~m}$ a $700 \mathrm{~m}$ ), com altas declividades $\left(26^{\circ}\right.$ a $\left.36^{\circ}\right)$ e exposição sul (S) e sudeste (SE), em solos do tipo latossolo vermelho-amarelo $\left(\mathrm{LVa}_{1}\right)$, cobertura vegetal de porte arbóreo baixo $(\mathrm{Ab})$, vertentes retilíneas (VR), litologia do tipo migmatitos estromatíticos (AcMn), em áreas onde a precipitação média do trimestre mais chuvoso esteve entre 1.100 $\mathrm{mm}$ e $1.200 \mathrm{~mm}$ e a precipitação média anual entre $3.200 \mathrm{~mm}$ e $3.600 \mathrm{~mm}$. 


\title{
LANDSLIDE HAZARD MAPPING IN THE CUBATÃO REGION, SP
}

\author{
Author: MARCO AURÉLIO NALON \\ Adviser: Prof. Dr. HILTON THADEU ZARATE DO COUTO
}

SUMMARY

Serra do Mar in Cubatão region is an area of contrast between the preservation of the enviroment and human settlement. There have been mass movements in this region, whose causes may be natural, but that are intensified by human action. The existence of highways, pipelines, industries, housing developments and other structure, in that region can cause these eroding processes to have tragic consequences, mainly to the population and to the enviroment. In order to contribute to the prevention of these occurrences the aim of this study was the mapping of landslide hazard, based on thematic maps of vegetation cover, pedology, lithology, morphology, hypsometry, clinography, aspect and rainfall, considered as instability factors. A geographic information system (GIS) was used as a tool, together with multivariate statistical model, the discriminant analysis. The area under stuty comprised an area of 10,706.9 ha, and included the valleys of Mogi, Perequê, part of Pilöes and part of Cubatão rivers. It was divided into terrain units of as cell grid of $30 \mathrm{~m} \times 30 \mathrm{~m}$. The thematic maps were converted into digital raster format. Areas both with and 
without landslide were sampled as to their hypsometric, clinographic, aspect, rainfall, pedologic, vegetation cover, morphologic and lithologic features. These data underment discriminant analysis, based on which a discriminant linear function was generated, in which weights were attibuted to each instability factor in proportion to their contribution to the occurrence on non-occurrence of landslides. The posterior probability of an area being a landslide or not was estimated on the basis of this function, the hazard being considered. A validation sample indicated its efficacy in the classification of areas as exibiting or not exibiting landslides in $82.41 \%$ of the sample. Its application in each terrain unit of the area under study generated a map of landslide hazard at five levels: very low $(44.4 \%)$, low $(10.2 \%)$, average $(9.3 \%)$, high $(12.9 \%)$ and very high $(12.7 \%)$. The highest weights in the discriminant function were attributed to clinography, average rainfall of the rainiest trimester, pedology and lithology. Areas with high an very high landslide risk that were found in average and high slope (300 $\mathrm{m}$ a $700 \mathrm{~m}$ ), with high declivity $\left(26^{\circ}\right.$ to $\left.36^{\circ}\right)$, and southern (S) and southeastern (SE) aspect, in latosoil red-yellow $\left(L \mathrm{La}_{1}\right)$, vegetation cover of low trees $(A b)$, rectilinear slope (VR), lithology of the migmaticts estromaticts (AcMn), in areas where the average rainfall of the rainiest trimester was between $1,000 \mathrm{~mm}$ and $1,200 \mathrm{~mm}$ and de annual average rainfall was between $3,200 \mathrm{~mm}$ and $3,600 \mathrm{~mm}$. 


\section{INTRODUÇÃo}

Em 1661, o Governo da Capitania de São Vicente mandou construir a Estrada do Mar, ligando São Vicente ao Planalto de Piratininga. Em 1789, o trecho de serra do Caminho do Mar foi pavimentado, sendo chamado Calçada de Lorena. Em 1844 foi concluída a Estrada da Maioridade, usando parte do traçado da Estrada do Mar, ficando abandonada até 1905, devido à concorrência com a ferrovia inaugurada em 1867. Em 1920 Rudge Ramos reconstruiu a estrada e em 1939 iniciaram-se as obras da Via Anchieta, ligando a Capital a Santos, que teve a pista ascendente inaugurada em 1947 e a segunda em 1953, com um total de 58 viadutos, 18 pontes e 5 túneis. Em 1968 , - Governo de São Paulo decidiu pela construção da Rodovia dos Imigrantes, inaugurada em 1974, e atualmente encontra-se em obras a construção da pista ascendente.

Na década de 50, com a instalação de uma refinaria petroquímica, iniciou-se a industrialização na região de Cubatão, seguindo-se instalação de complexos industriais de ferro, aço, petroquímica e fertilizantes. Esse desenvolvimento industrial foi implementado sem um plano de controle de poluição e proteção do meio ambiente. As indústrias de Cubatão, durante mais de três décadas, descarregaram toneladas de vários poluentes do ar causando a progressiva destruição da vegetação. Esta degradação afetou diretamente a estabilidade das vertentes e, movimentos de massa provocaram a formação de depósitos de materiais soltos e inconsistentes, denominados massas de "talus", 
ao longo dos seus patamares e do sopé de suas encostas. Esses materiais são caracterizados por apresentarem condições críticas de estabilidade. Embora os materiais das encostas possam sofrer escorregamentos naturais sem a intervenção humana, é claro, que a ação do homem tem provocado e acelerado de forma catastrófica e incontrolável esses escorregamentos e movimentos.

Nos últimos trinta anos, eventos desastrosos de movimento de massa ocorreram de cada 5 a 10 anos durante a estação chuvosa de novembro a abril, como é mostrado na Tabela 1.

Tabela 1. Eventos desastrosos de movimento de massa ocorridos durante a estação chuvosa de novembro a abril.

\begin{tabular}{ccc}
\hline Mês/Ano de ocorrência & número de escorregamentos & área total $\left(\times 10^{4} \mathrm{~m}^{2}\right)$ \\
\hline$---/ 1962$ & 40 & 7,6 \\
\hline fev./1971 & 218 & 70,6 \\
\hline jan./1977 & 303 & 94,4 \\
\hline fev./1980 & 187 & 58,6 \\
\hline jan./1985 & 905 & 194,3 \\
\hline dez./1989 & 215 & 103,4 \\
\hline
\end{tabular}

A maior parte do escorregamentos ocorreram nas vertentes das bacias dos rios Mogi, Perequê e baixo Cubatão.

Em 30 de agosto de 1977, com o Decreto Estadual $n^{\circ} 10.251$, foi criado Parque Estadual da Serra do Mar - SP, com uma superfície de 315.390 ha, sendo o maior Parque Estadual paulista, sob a administração do Instituto Florestal. Este Parque, localiza-se na unidade geomorfológica denominada Província Costeira, que por sua vez compreende duas unidades geomorfológicas distintas: a Serrania Costeira, de relevo montanhoso íngreme, e as Baixadas Litorâneas, de terrenos mais planos. Sua extensão vai do litoral norte do Estado, divisa com o Estado do Rio de Janeiro, até o litoral sul, nos 
municípios de Peruíbe e Pedro de Toledo. Engloba os municípios de Ubatuba, Caraguatatuba, São Sebastião, Bertioga, Santos, Cubatão, Praia Grande, Mongaguá, Itanhaém, Peruibe e outros localizados no Planalto Atlântico.

O Governo do Estado de São Paulo, estabeleceu em 1985 uma Comissão Especial de Recuperação da Serra do Mar na Região de Cubatão, com o objetivo de definir e implementar as ações necessárias para a prevenção de desastres na região. Essas ações foram definidas como sendo a longo prazo, envolvendo controle da poluição industrial e revegetação das vertentes, e a curto prazo, em caráter de emergência, com a construção de estruturas de proteção como barragens de "gabião" em canais, redução do volume de produtos perigosos armazenados em áreas críticas durante o período chuvoso, e implementação de um sistema de previsão de eventos de movimentos de massa, baseado em dados de precipitação.

Os principais riscos geotécnicos para a região de Cubatão estão relacionados com a ocorrência generalizada de escorregamentos, tendo como conseqüências a destruição de rodovias, ferrovias, dutos, residências ("bairros cota"), danos à hidrelétrica "Henry Borden" e aos tanques de armazenamento e dutos industriais, produzindo a descarga de produtos altamente perigosos para a atmosfera.

A cobertura vegetal, predominante na região, é a Floresta Latifoliada Tropical Úmida da Encosta do tipo florestal, que caracteriza a cobertura vegetal das Escarpas da Serra do Mar, em São Paulo, onde a inclinação das vertentes é bastante acentuada, os solos apresentam-se rasos e quando desprovidos de manto de vegetação são facilmente erodidos.

A combinação do gradiente de declividade, configuração da vertente e condições da cobertura vegetal pode ser apontada como a principail causa de escorregamentos, $e$ as precipitações intensas como $\circ$ fator deflagrador. 
A intervenção humana tem se resumido na remoção ou destruição da cobertura vegetal protetora, causando a exposição do solo aos agentes climáticos, ocasionando erosões, infiltração maior de água, saturação excessiva do subsolo e aumento da carga sobre as camadas de materiais instáveis com a construção de pistas e outras estruturas.

Os fenômenos de movimentação de materiais, tais como, escorregamentos, queda de blocos e rastejo, resultam da evolução natural do setor escarpado, ocorrendo em virtude das declividades acentuadas, precipitações intensas e formações superficiais instáveis, e dinamizados pela ocupação antrópica.

O clima da região foi classificado como tropical de altitude e apresenta estações chuvosas definidas, com o período muito chuvoso que se estende do mês de outubro até março, um período pouco chuvoso entre os meses de junho e agosto, e um período intermediário que compreende os meses de abril, maio e setembro. A maior freqüência de totais diários de precipitação maiores que $100 \mathrm{~mm}$ e $200 \mathrm{~mm}$ tem ocorrido nos meses de janeiro, fevereiro e março. No posto pluviométrico E3-101 Cubatão, do D.A.E.E. (Departamento de Águas e Energia Elétrica) a precipitação média total mensal registrada no período entre 1969 e 1986 é mostrada na Figura 1.

Altas taxas de precipitação aumentam o teor de umidade no solo, que associado à grande declividade do terreno e cobertura vegetal degradada, criam condições para a diminuição da resistência do solo, que pode resultar em movimentos de massas de solo e blocos.

A estabilidade das encostas da Serra do Mar, depende então, não só de um fator isolado, mas de um conjunto de fatores interligados. Entre os fatores naturais, temos a cobertura vegetal, os solos onde esta se apoia, características do relevo tais como clinografia, hipsometria e exposição da vertente, a litologia, a morfologia e a precipitação pluviométrica. A ação do homem no meio atua como fator não natural. Trata-se, portanto, de uma 
questão complexa, que envolve diversos fatores espacialmente distribuídos pelo terreno.

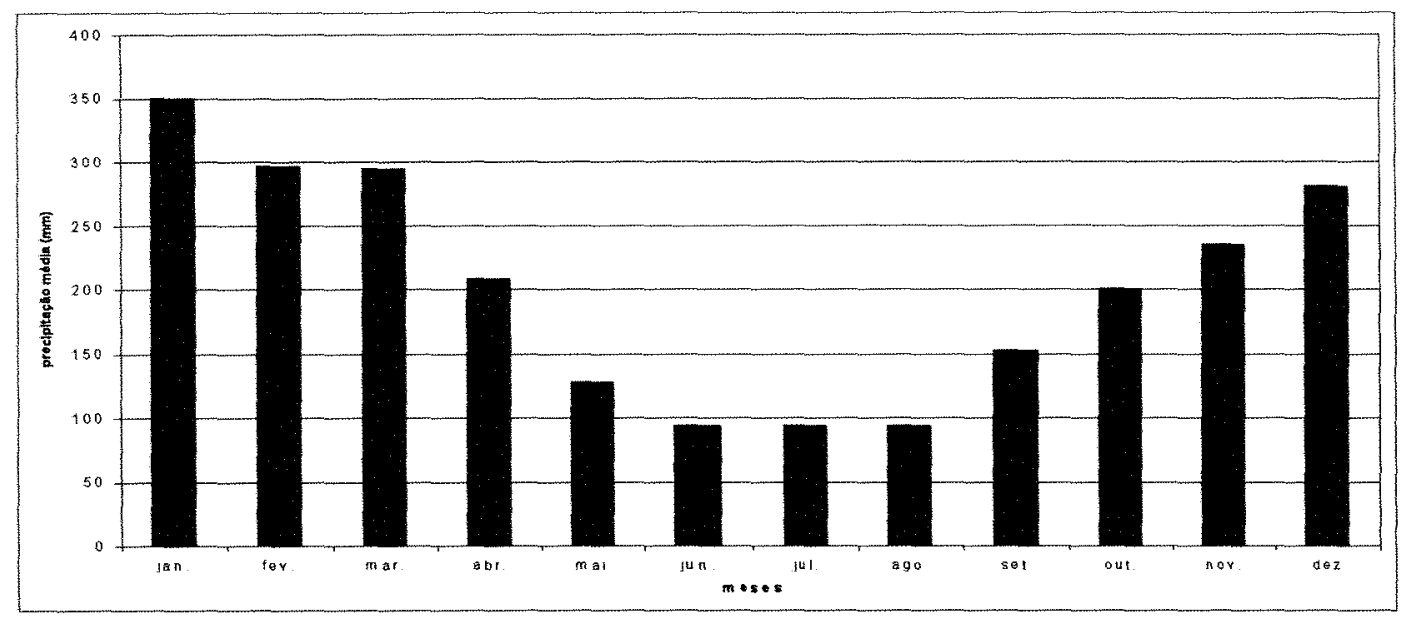

Figura 1- Precipitação média total mensal registrada no período entre 1969 e 1986 no posto pluviométrico E3-101 Cubatão, do D.A.E.E. (Departamento de Águas e Energia Elétrica).

Frente a esse quadro, o objetivo desse estudo foi produzir um mapa de risco de escorregamento, a partir da estimativa da contribuição relativa de cada fator natural descrito acima na geração de escorregamentos.

Um estudo por métodos analógicos, de todas os fatores envolvidos e suas interrelações, implicaria numa grande demanda de trabalho e tempo, estando ainda sujeito a generalizações devido às técnicas e à subjetividade dos analistas.

Outra forma de analisar o problema, proposta nesse estudo, foi através de métodos digitais, utilizando Sistemas de Informações Geográficas (SIG). Sistemas de Informações Geográficas têm se desenvolvido em paralelo com as ciências da computação e seu uso está ligado a sistemas de processamento digitais. Suas primeiras aplicações, na década de 60, restringiam-se a órgãos governamentais, e seus custos eram elevados. Hoje, o avanço tecnológico e diminuição considerável dos custos de hardware e 
software, tem permitido a difusão dos SIG's em todo o mundo, tornando-o uma ferramenta ímpar para estudos que envolvam análises espaciais e temporais. Entre as operações possiveis dentro de um SIG, destacamos a medida de distâncias, medida de áreas, álgebra de mapas, operações booleanas, conversão de formatos vetorial para raster e vice-versa, geração de modelos digitais do terreno (MDT) e seus produtos tais como, mapa de declividade, orientação de vertente e perfil de terreno. Para a alimentação de informações espaciais de um SIG, como no caso de mapas temáticos, foram utilizados sistemas especializados em desenho digital, os chamados sistemas CAD (Computer Aided Design), que possuem ferramentas precisas para o traçado de linhas, pontos e polígonos. O SIG permitiu que se obtivesse respostas mais rápidas, com maior precisão e confiabilidade.

$\mathrm{Na}$ construção do modelo de risco de escorregamento, utilizou-se um método indireto estatístico multivariado, a análise discriminante, que permitiu classificar a superfície da terra em diferentes graus de risco, usando como unidade de terreno uma grade de células. O risco de escorregamento foi calculado como uma probabilidade espacial de ocorrência de escorregamento, informando sobre a suscetibilidade do terreno para movimentos de massa. Cicatrizes de escorregamentos, ocorridos em 1985, foram utilizadas como amostra de análise e validação na construção do modelo de risco de escorregamento. O produto final foi um mapa de risco de escorregamento da área de estudo, classificado em risco de escorregamento muito baixo, baixo, médio, alto e muito alto.

A área selecionada para esse estudo localiza-se no Parque Estadual da Serra do Mar, SP, região de Cubatão e compreende os vales do rio Mogi, rio Perequê, parte dos vales do rio Pilões e rio Cubatão. 


\section{REVISÃO DA LITERATURA}

AGUIAR \& KRELING (1984) explanando sobre os procedimentos para a elaboração de cartas de classes de declividades de vertentes, a partir de uma base topográfica em curva de nível, colocaram que uma avaliação visual qualitativa do espaçamento planimétrico entre as curvas de nível, em uma carta topográfica, nos sugere uma avaliação de declividade, e que a precisão da representação numérica da declividade depende da fidelidade da carta topográfica utilizada. Assim cartas em grandes escalas (1/10.000, $1 / 5.000)$ apresentariam as menores eqüisdistâncias entre curvas e menores distorções, da realidade. Quanto menor for a escala da carta e mais acidentada for a superfície do terreno, menos precisa seria a carta de declividade produzida, devendo-se levar em consideração o objetivo a que se destina a carta de declividade e as limitações da carta topográfica utilizada, bem como sua precisão. Sugeriram ainda que para correlação com processos de dinâmica morfogenética, as classes de declividade deveriam ser estabelecidas em graus. Descreveram um método para construção de uma "régua" de referência, sobre uma tira de papel poliester transparente, em função da escala da carta topográfica e da eqüidistância das curvas de nivel, onde seriam representadas as distâncias planimétricas entre as curvas de nivel equivalente aos limites das classes de declividade que se deseja obter. A "régua" seria deslocada o mais perpendicular possivel entre as duas curvas de nível analisadas, até que houvesse coincidência entre um de seus segmentos de reta e a distância entre as curvas. 
ALVES (1990) ressaltou a necessidade de se compatibilizar a escala e projeção dos mapas utilizados em um sistema de informação geográfica, principalmente quando estes possuem fontes diferentes. e que a escala de trabalho em sistemas de informação geográfica depende da extensão da área de trabalho. Na prática, os mapas utilizados poderiam estar em escalas diferentes, sendo comum sua mudança de escala, mas o uso de informações em escalas maiores do que a original poderia acarretar problemas, devido ao acréscimo de informações não existentes na escala original. Quanto aos sistemas de projeção de mapas, no Brasil, comentou que os mais comumente utilizados são UTM, Lambert, Mercator e Policônica. O elipsóide (datum) utilizado nas cartas em projeção UTM, a partir de 1972, é o SAD, tendo sido utilizado anteriormente o de Hayford (Córrego Alegre).

ALVES \& PAIVA (1990) descreveram o sistema de informação geográfica, SISGERCO/NCl, desenvolvido para o Programa Nacional de Gerenciamento Costeiro, pelo INPE, dando ênfase aos objetivos do mesmo, que foram criar uma base de dados geocodificados, incorporar modelos numéricos de terreno e imagens de satélite, analisar e combinar informações armazenadas, produzir saídas gráficas e possibilitar o desenvolvimento de aplicativos para resolução de problemas específicos.

ANBALAGAN \& SINGH (1996) explicaram que o risco de escorregamento depende de dois fatores, que são a probabilidade de escorregamento e o potencial de danos. A probabilidade de risco é a probabilidade de ocorrência do perigo, que deve ser indicada em relação ao período de tempo de sua ocorrência (curto, médio e longo prazo), e de acordo com a escala pode ser regional (1:25.000 - 50.000), semi-regional (1:10.000 $15.000)$ e detalhada (1:1.000 - 2.000). Fenômenos naturais são considerados perigos, que podem ser existentes ou em potencial. Em escala regional os métodos baseiam-se nos fatores causadores da instabilidade das encostas, e ajudam a identificar as áreas para estudos mais detalhados. Utilizaram a Risk 
Assessment Matrix (RAM), ou Matriz de Avaliação de Risco (MAR), em Kumaun, Himalaya, Índia, para um mapeamento de risco de escorregamento. Definiu o Zoneamento do Risco de Escorregamento (ZRE), como uma divisão da superfície da terra em zonas que variam em grau de estabilidade baseado sobre a significância estimada dos fatores causa, sendo que risco se refere a natureza dos danos, que pode ser perda de vidas ou danos materiais. $\mathrm{O}$ dano depende da natureza do uso padrão do solo. Recomendou esta técnica para estudos de planejamento de projetos que requerem técnicas de avaliação de risco, econômicas e rápidas. O ZRE foi preparado sobre um mapa de facetas, derivado de um mapa topográfico, onde as encostas são divididas em facetas delimitadas por interflúvios, cumes, barrancos e rios. O mapa ZRE usou um esquema de relações numéricas chamado Fator de Avaliação de Risco de Escorregamento (FERE), que estimou a extensão do dano que pode resultar de um escorregamento. $\mathrm{O}$ dano pode ocorrer na mesma vertente onde há risco, ou estender-se para vertentes vizinhas e pode ser classificado em: perda de vida e lesões; perda de terra e propriedades. Essas categorias possuem diferentes conseqüências e devem ser avaliadas diferentemente. A perda de vida e lesões pode ser estimada pelo número de moradias. O Mapa de Avaliação de Risco deve considerar a topografia da área, a natureza da falha e a geologia. Concluíram que o mapa de avaliação do risco de escorregamento possibilitou o planejamento de medidas emergenciais, ou a longo prazo, para a estabilização das encostas

ARGENTO \& MARQUES (1988) apresentaram o projeto de gerenciamento costeiro sob a responsabilidade da Comissão Interministerial para Recursos do Mar - CIRM, onde foi desenvolvido o Sistema de Informações Geoambientais para a reprodução automática das informações e entrecruzamento dos planos de informações, possibilitando a análise e avaliação dos efeitos de impactos ambientais, baseado nos mapas temáticos: plano-altimétrico, uso e cobertura do solo atual, geomorfológico, geológico e 
faciológico, vocações agrárias, qualidade das águas, fauna e flora, parâmetros oceonográficos, climáticos, socioeconômico, planos e zoneamentos existentes e uso projetado, associando o Gerenciamento Ambiental ao Zoneamento, Monitoramento, Ambiente e Sistemas de Informação.

AUGUSTO FILHO (1994) desenvolveu uma proposta metodológica para a elaboração de cartas de risco de escorregamentos voltadas às condições ambientais e socioeconômicas brasileiras, em uma estrutura compatível com a utilização de cartografia digital e sistema de informações geográficas, no caso o IDRISI, para o município de Ilhabela, São Paulo, a partir de mapas temáticos de hipsometria, geologia, geotecnia, declividade, uso do solo, cicatrizes de escorregamentos e pontos de trabalho de campo. Avaliou diferentes classes de risco a partir do cruzamento entre as zonas de suscetibilidade a escorregamentos e os grupos de ocupação do solo, chegando a zonas de risco atual, que requerem ações mais imediatas e corretivas, e de risco potencial, que requerem ações de planejamento. Concluiu que o uso das técnicas digitais de cartografia e sistemas de informações geográficas, foram compatíveis com a proposta do estudo.

BACCARO (1985) descreveu cinco tipos de movimentos de massa observados nos vales do Cubatão e do Mogi: rastejo, movimento lento de camadas pouco profundas em vertentes com inclinação em torno de $5 \%$, ocorrendo independentemente das chuvas, podendo ser ativado pela mesma; subsidência, acomodamento lento de estratos mais profundas da zona de blocos e dos taludes de detritos, relacionado ao escoamento de material subterrâneo, ocorrendo independentemente da pluviosidade e ação antrópica; escorregamento, movimento de massa rápido, podendo envolver água, partículas, blocos e outros materiais sólidos, em declividades acima de $10 \%$, ocorrendo nas vertentes das escarpas, envolvendo todos os tipos de formações superficiais, sendo mais freqüente onde a ação antrópica é mais intensa; subsidência, movimento rápido, comum nos taludes de detritos, 
quando o escoamento subterrâneo é muito intenso; queda de blocos isolados, ocorrendo geralmente em vertentes com inclinação superior a $20 \%$ e nas barrancas do canais fluviais e pluviais, sendo acelerada pela pluviosidade, em capoeiras ou onde não há vegetação. A pluviosidade anterior acumulada propiciaria o encharcamento e a queda de resistência dos materiais. Constatou que as vertentes dos vales do Mogi e Cubatão, com inclinações superiores a $30^{\circ}$, foram as mais atingidas pelos movimentos de massa, onde predominaram escorregamentos de forma alongada na alta encosta, em forma de cicatriz e colher nos interflúvios em forma de crista, e que as escarpas possuem a maioria de suas vertentes com declividade superior a $45^{\circ}$, seccionadas, assimétricas, com orientação geral ENE-WSW e NE-SW.

BOCCO (1991) utilizou um método de classificação integrando sensoriamento remoto e Sistema de Informações Geográficas para mapeamento do uso do solo e processos erosivos em um bacia de cerca de $250 \mathrm{Km}^{2}$ no México Central, onde ocorreram processos erosivos acelerados, a partir de imagem do satélite LANDSAT Thematic Mapper. Após análise digital da imagem, obteve um mapa prévio com 26 classes espectrais de cobertura do solo, que posteriormente foi complementado com informações geomorfológicas e de declividade através de sistema de informações geográficas, gerando um modelo digital do terreno e um mapa final com 7 classes de uso do solo, cuja precisão variou entre $75 \%$ e $85 \%$. Afirmou que o SIG permitiu a total incorporação do conhecimento de campo do pesquisador.

BURROUGH (1996) discorreu sobre o problema dos limites dos fenômenos geográficos, e colocou que devido à complexidade dos fenômenos naturais, que variam em escala, espaço e tempo, estudiosos do meio ambiente têm sido forçados a selecionar os aspectos mais importantes de um dado fenômeno e usá-los como base para transferência e armazenamento das informações. Dessa forma, a melhor generalização de um fenômeno para um, não é satisfatória para outro. Uma questão sobre os modelos geográficos, que 
tem sido levantada pelo pesquisadores do meio ambiente, é a diferença entre o modelo do objeto exato e o modelo do campo contínuo. Entidades geográficas ideais devem ter fronteiras espaciais e um conjunto de atributos bem definidos. Entretanto há fenômenos geográficos, tais como pressão do ar e elevação, que são usualmente representados por superfícies matemáticas que variam continuamente no espaço-tempo. Fenômenos geográficos com modelos do objeto exato, são representados por linhas, pontos, áreas e volumes definidos em um sistema de referência absoluto. De uma forma simples, fenômenos geográficos com modelo do campo contínuo, não possuem fronteiras, e seus atributos variam continuamente no espaço, descritos por funções matemáticas que podem ser visualizadas por linhas de contorno. Ambos os modelos podem ser representados por estruturas vetoriais e raster. Chamou a atenção para o fato de que, nos fenômenos naturais, aumentar o número de observações nas zonas de fronteira não melhora necessariamente sua precisão, mas sim, revela novos detalhes da variação dessa zona.

BRÄNDLI (1996) colocou que muitos processos e fenômenos do meio físico dependem direta ou indiretamente do relevo, e sendo assim, a superficie da Terra é comumente modelada por modelos digitais de terreno (MDT). Nos últimos anos, os modelos digitais de terreno têm se tornado um dos maiores constituintes da tecnologia dos sistemas de informações geográficas (SIG); entretanto, há dois problemas a serem resolvidos. O primeiro é a integração dos dados do MDT com os sistemas de informações geográficas. Muitos problemas relacionados com o relevo são resolvidos apenas em sistemas especiais de MDT, que requerem uma transferência de dados custosa para a análise em SIG. O segundo, é a limitada funcionalidade de análise de SIG ou MDT, reduzindo a aplicabilidade dos mesmos consideravelmente. Enquanto é simples calcular a declividade e a exposição de algumas localidades específicas, ainda não há solução para o problema de extrair alguns elementos da paisagem, tais como, colinas ou vales. A superfície de 
terreno é contínua, e deve ser modelada como tal. Entretanto, as representações de MDT mais usadas, grade regular, rede irregular de triângulos (TIN) e contornos são discretizações desse conceito.

CAMARGO et al. (1972) consideraram a mata atlântica como "clímax", fisionomicamente constituída por indivíduos de porte arbóreo bem desenvolvido, podendo alcançar de 30 a 40 metros de altura, tratando-se de uma mata bem estratificada, com três andares característicos.

CARNEIRO (1980) ressaltou que a fisionomia e a estrutura da vegetação seriam as características mais salientes que podem ser reconhecidas por um fotointérprete, podendo-se realizar inferências ecológicas através de chaves de padrões de vegetação, utilizando-se o conhecimento das características de certos habitats.

CASTRO (1993) em um estudo morfodinâmico na bacia do rio Mogi, Cubatão, SP, utilizando o sistema de informações geográficas SGI/INPE, e os mapas temáticos de morfologia, cobertura vegetal, uso do solo, geológico, declividade, orientação de vertentes, hipsométrico e pluviométrico, obteve como resultado um mapa digital da morfodinâmica da bacia do rio Mogi, com cinco graus de instabilidade morfodinâmica, que comparado ao mesmo mapa produzido por métodos convencionais, mostrou maior detalhamento de classificação. Ressaltou os cuidados que devem ser tomados na digitalização da topografia e na produção de cartas de declividade e orientação de vertentes por métodos digitais, adotando-se uma eqüidistância das curvas de nível, compativel com a escala da carta.

Companhia de Tecnologia de Saneamento Ambiental, CETESB, (1987) no mapeamento da cobertura vegetal $e$ das cicatrizes de escorregamentos em um área que abrange as bacias dos rios Mogi, Quilombo e Cubatão (a partir da via Anchieta), na escala 1:25.000, constatou que a degradação da cobertura vegetal se verificou em todo o vale do rio Mogi em grande parte do trecho da Serra do Cubatão, com áreas de forte degradação 
nas imediações das indústrias, e que a área ocupada pela classe Mata, ficou restrita às encostas íngremes do vale do rio Quilombo e pequenas manchas na Serra do Cubatão. Analisou as classes florestais derivadas da Mata Atlântica, excluindo as classes Manguezal e Reflorestamento.

Companhia de Tecnologia de Saneamento Ambiental - CETESB , (1991) em uma avaliação do estado de degradação dos ecossistemas da Baixada Santista, São Paulo, levantou que o município de Cubatão, com 148 $\mathrm{Km}^{2}$ de extensão territorial, era recoberto originalmente por $91 \mathrm{Km}^{2}$ de Mata Atlântica, $24 \mathrm{Km}^{2}$ de matas de restinga e $29 \mathrm{Km}^{2}$ de manguezais além dos 4 $\mathrm{Km}^{2}$ de corpos d'água, e que, atualmente, $10 \mathrm{Km}^{2}$ apresentam um bom estado de preservação, sendo $5 \mathrm{Km}^{2}$ de Mata Atlântica e $5 \mathrm{Km}^{2}$ de manguezais. Da área restante dos ecossistemas originais, $33 \mathrm{~km}^{2}$ estariam ocupados por estruturas urbanas, industriais e portuárias; $25 \mathrm{Km}^{2}$ degradados por desmatamentos, cortes seletivos e aterros; $75 \mathrm{Km}^{2}$ degradados pela poluição industrial. Com a degradação da vegetação, agravaram-se as condições de instabilidade das encostas, desencadeando processos erosivos que se estendem para todo o vale do rio Mogi e parte da bacia do rio Cubatão.

COLANGELO (1995) explanou sobre o equilibrio de forças sobre os constituintes de um sistema de vertente natural, onde a força de cisalhamento é gerada a partir da interação entre a força gravitacional, a carga sobrejacente ao ponto considerado e a declividade do terreno, principalmente dos dois últimos, uma vez que a força gravitacional é constante. Tanto a força de cisalhamento como a de resistência ao cisalhamento possuem fatores que podem ser intrínsecos, que correspondem à caracteristicas mecânicas próprias dos materiais da vertente, e extrínsecos ligados a outros elementos do meio físico circundante. As fortes declividades dos setores convexo e retilíneo do perfil de vertente, são sustentadas por materiais que devem apresentar uma dosagem adequada de fração areia, com baixo grau de seleção, capaz de gerar força de atrito passiva, necessária a equilibrar a força de cisalhamento 
ativa. $\mathrm{Na}$ alta vertente os materiais são sustentados em virtude de um incremento de atrito mecânico, vinculado a uma maior concentração relativa de areias mal selecionadas, enquanto na baixa vertente tal sustentação é devida, principalmente, ao aumento relativo de coesão química, vinculada notadamente às argilas. Nos setores convexos das vertentes mais pobres em argila, o dessecamento do solo pode produzir um maior aumento da coesão que nos setores retilíneo e côncavo basais, mais úmidos. Esse processo é mais intenso quando a cobertura vegetal é eliminada e o solo é atingido diretamente pela radiação solar. O papel da cobertura vegetal é essencial para manter o dessecamento e endurecimento dos horizontes superficiais do solo em níveis aceitáveis. O sistema vertente, possui mecanismos que ajustam suas formas, materiais e processos de forma a favorecer um equilíbrio relativo. Ao ser atingido o limiar de resistência devido a um colapso coesivo generalizado, todo o material escoa com um fluído viscoso, gerando um fluxo de lama. Quando há apenas uma queda relativa de coesão na extensão de uma superfície de ruptura, o atrito entre as partículas do solo não é suficiente para anular a ação da força cisalhante, o material escorrega no estado plástico, ou mesmo semisólido. Destacou que a ação do homem também é condicionante no que se refere a tipologia, extensão e freqüência de ocorrência destes fenômenos.

COLANGELO (1996) expôs que a inumerável variedade de formas de relevo da superfície da Terra, pode ser reduzida a um pequeno número de tipos de formas geometricamente simples, denominadas "feições mínimas", que seriam as formas geometricamente mais simples de serem identificáveis em sensores remotos ou cartas topográficas. A curva de nível não seria mais do que uma seqüência contínua de três tipos de formas geométricas elementares: côncava, convexa e retilínea. As feições mínimas representariam unidades de relevo que projetadas nos planos ortogonais de perfil e planta, possuiriam, em cada um, apenas uma das três formas anteriores, podendo haver somente nove combinações destas. Decompondo e identificando a 
superficie do terreno dentro das nove combinações possiveis, obter-se-ia unidades morfológicas onde poderiam ser medidas a área, média da declividade e orientação da vertente. A carta de feições mínimas seria simultaneamente um mapa morfológico, de declividade, de orientação de vertente e de tipologia de fluxos hídricos de superfície, com aplicações em diversos ramos do conhecimento, tais como Hidrologia, Agronomia, Engenharia Florestal entre outros.

COSTA et al. (1996) delimitaram e caracterizaram áreas de preservação permanente por meio de um sistema de informações geográficas, - IDRISI, em uma localidade do município de Viçosa-MG, a partir da carta topográfica, mapa de hidrografia e mapa de uso da terra, onde identificaram os remanescentes florestais, culturas agrícolas e pastagens. Utilizaram uma grade de células de $30 \mathrm{~m} \times 30 \mathrm{~m}$. Concluíram serem satisfatórios os resultados obtidos, que mostram além das áreas de preservação permanente, a porção das mesmas com uso indevido.

CRUZ (1975) em estudos na Serra do Mar em Caraguatatuba, verificou que os maiores escorregamentos do verão de 1967 ocorreram acima do limite de $40 \%$ de declividade, ou seja, aproximadamente $22^{\circ}$ e, que acima de $15^{\circ}$ já havia grande freqüência de cicatrizes de erosão ligadas aos movimentos do solo.

Para DE BIASI et al. (1977) graças aos avanços na área da computação eletrônica, muitos métodos de determinação de índices morfométricos não caíram em desuso, visto as facilidades oferecidas para a realização de cálculos matemáticos nos computadores. Para a produção de uma carta de orientação de vertentes deve-se utilizar cartas topográficas em escala compatível com sua aplicação, com um sistema de quadrículas orientado pela linha Norte-Sul da carta. Apresentaram o método manual de Gol'Tsberg (1969) que utiliza um esquadro de $45^{\circ}$ que percorre a carta mantendo seus catetos paralelos aos eixos $X$ e $Y$ das quadrículas, marcando- 
se um ponto para cada ponto de tangência entre a hipotenusa do esquadro com a curva de nível. Unindo-se estes pontos obtêm-se segmentos sobre a vertente com uma certa orientação. O resultado seria um mapa de orientação de vertentes segundo os quatro pontos cardeais (N, S, E e O). Sugeriram a utilização de um gabarito octogonal transparente, representando as oito faces de orientação, para um melhor detalhamento, destacando a aplicação das cartas de orientação de vertentes em estudos de cadastramento do valor da terra, planejamento agrário e urbano.

DE BIASI (1992) apresentou os métodos de confecção de carta clinográfica proposto por Wentworth e pela utilização da representação por "facetas". Pela técnica de Wentworth, foi construída uma malha regular de quadrados, com orientação de um dos nortes da carta topográfica sobre a qual foi traçada, determinando-se para cada quadrado uma diagonal que cruzou o maior número de curvas de nível, inscrevendo no mesmo esse número. Em seguida estabeleceram-se as classes de declividade de acordo com os objetivos do trabalho. Por essa técnica não se obteve a declividade em graus ou percentagem diretamente. Alertou para o tamanho do quadrado adotado, que estava ligado à escala da carta base. Quanto menor a escala, menor deverá ser elemento da malha, e propôs o uso de uma malha de hexágonos para melhor traçado da linha divisória das classes de declividade. A técnica das "facetas" também utilizou uma base topográfica como a anterior, porém as classes de declividade foram previamente determinadas pelo usuário. Nesse sentido sugeriu o uso de classes de declividade já estabelecidas pela legislação vigente para diferentes usos do solo, sendo que estas não devem ultrapassar o número de seis classes, para não introduzir "ruídos" que dificultem a interpretação visual da mesma. Em seguida construiu-se um ábaco ou diapasão, com as classes escolhidas, sobre um suporte transparente, o qual percorreu o espaçamento entre as curvas, de forma que as extremidades dos segmentos que representassem as classes fossem tangentes a duas curvas 
simultaneamente, da forma mais perpendicular possivel. Destacou que as cartas de declividade podem ser utilizadas em trabalhos de correlação com outros tipos de fenômenos geográficos ligados à topografia local, e ainda em qualquer tipo de zoneamento (DE BIASI, 1970).

De PLOEY \& CRUZ (1979) consideraram a declividade acentuada, a grande amplitude do relevo, a pluviosidade elevada, a drenagem superficial e subterrânea, a vegetação original alterada pela ação antrópica e a geologia complexa, como fatores responsáveis pela instabilidade das escarpas da Serra do Mar.

DIKAU et al. (1996) colocaram como um aspecto importante na pesquisa de escorregamentos, a capacidade de armazenar, manipular e analisar dados espaciais e temporais. Especialmente com respeito à aplicação de novas tecnologias de captura de dados, como modelos digitais de elevação, sensoriamento remoto e radar, ferramentas computacionais são necessárias para garantir a efetiva ligação entre modelos e dados. Com o crescente número de escorregamentos investigados, há uma demanda em conseguir fácil acesso aos dados de escorregamentos que podem ser usados para investigar padrões temporais em termos de uma análise de série temporal, ou avaliar padrões espaciais de escorregamento em termos de avaliação de riscos regionais. Enfatizaram que o sistema de informação geográfica (SIG) e bancos de dados são ferramentas técnicas que não podem substituir a necessidade de aperfeiçoar o entendimento dos processos de escorregamento em si mesmo, no espaço e no tempo. Realizaram uma pesquisa sobre as aplicações de SIG e bancos de dados em pesquisas de escorregamentos na Europa. Para tanto enviaram um questionário a grupos de pesquisadores em universidades, agências governamentais e consultores de sete países europeus e receberam 49 respostas, bastante diferentes em sua características. Vinte e seis grupos responderam que têm usado bancos de dados e trinta grupos têm usado SIG em pesquisas de escorregamentos. Cerca de $50 \%$ das respostas indicam que 
têm usado ambas as ferramentas. Concluíram que dentro do conceito de projetos de pesquisa de escorregamentos, SIG e bancos de dados estariam localizados entre a captura de dados e modelamento. A capacidade dos modernos SIG's dariam suporte ao desenvolvimento de avaliações espaciais de risco de escorregamentos em escalas regionais e maiores. Essas avaliações seriam caracterizadas pelas declarações de probabilidades e cenários de risco de escorregamentos sobre o futuro de uma vertente em termos de sua estabilidade. Planejadores e tomadores de decisões poderiam compreender mapas de risco de escorregamento mais facilmente e com menor custo. Entretanto, permaneceria um alto grau de incerteza no modelamento espacial e temporal apesar do alto desenvolvimentos das ferramentas computacionais, isto devido principalmente a dados geotécnicos em escalas regionais insuficientes; localização incerta dos escorregamentos; dados de ocorrência temporal de escorregamentos insuficientes; acesso limitado e/ou existência de dados de fatores; disponibilidade limitada de dados digitais.

DOMINGUES (1983) considerou as formações superficiais, as formas $e$ as declividades das vertentes no estudo da dinâmica fluvial e evolução das vertentes das escarpas da Serra de Cubatão. Estes fatores, aliados à pluviosidade, representaram fortes impulsos de energia aos processos fluviais na dinâmica atual. Concluiu que, na área estudada, o escoamento fluvial promoveu a dinâmica de várias modalidades de processos, principalmente nas formações dos taludes de detritos que recapeiam as baixas vertentes e o canal fluvial. Estas características, aliadas à declividade predominante, superior a $22^{\circ}$, e precipitações de até $442,0 \mathrm{~mm}$ diários (29/01/76), justificaram a existência de "sumidouros" e de outros fenômenos de variações no comportamento do escoamento que caracterizam a complexidade do regime fluvial e a perenidade dos rios das escarpas.

Para EAST \& SIMONETT (1975) o imageamento representa a energia refletida, emitida e a transmitida de partes específicas do espectro 
eletromagnético e é registrado em diversos tamanhos, formas e escalas, sendo essencial na interpretação de imagens.

GAMA (1988) explicou que nas aplicações de cartografia digital, as informações da superfície terrestre seriam mapeadas no plano $(X, Y)$ correspondente à mesma, sobre o qual se representaria uma grandeza qualquer $Z$, que possuiria valores discretos sobre os pontos de coordenadas $(X, Y)$. Logo a função $Z(X, Y)$ seria discreta ao longo do espaço mapeado. Os valores de $Z$ poderiam ser adquiridos em uma malha regular de amostragem, ou assim distribuídos por interpolação matemática, obtendo-se matrizes numéricas de fácil arquivamento e manipulação, que permitiriam uma representação gráfica das informações. Uma das principais fontes de dados utilizada freqüentemente em cartografia tem sido o mapa topográfico convencional, e a transferência dos dados desse mapa para o computador vem sendo feita basicamente de duas maneiras: por digitalização ou varredura em scanner.

GOES (1990) em estudos ambientais, nas serranias costeiras da Baixada de Sepetiba, para prognóstico de movimentos de massa, com definição de áreas de risco de desmoronamentos/deslizamentos, utilizou o sistema de informação geográfica SAGA da URFJ, e os mapas geomorfológico, geológico, pedológico, altimétrico, clinográfico e de uso do solo, atribuindo, para cada um, pesos de 0 a 100, conforme seu grau de importância ao fenômeno estudado. Dentro de cada parâmetro, suas categorias também receberam notas de 0 a 10 . Dessa forma, verificou que fatores como forte gradiente de declividade, vegetação pouco densa, forte atuação antrópica estavam fortemente associados à suscetibilidade aos desmoronamentos/escorregamentos, sendo que encostas e topos dissecados com mais de $25^{\circ}$ de declividade associados aos solos Podzólicos vermelhoamarelo receberam valores máximos para a identificação de áreas criticas aos fluxos de massa. As áreas de risco "alto" e "muito alto" encontraram-se nas 
altas e médias encostas dos maciços rochosos muito íngremes com exposições rochosas alteradas e instáveis. Concluiu que desmoronamento/deslizamentos são eventos passíveis de prognósticos com técnicas de avaliação ambiental, utilizando como ferramenta a tecnologia de sistema de informação geográfico.

GUIDICINI \& IWASA (1976) realizaram estudos com dados de pluviosidade e escorregamentos na Serra do Mar, e comprovaram a ação de altas pluviosidades nos processos que acarretam o rompimento do equilibrio das vertentes e conseqüentes movimentos de massas. Segundo os autores, chuvas superiores a $12 \%$ da pluviosidade média anual tenderam a provocar escorregamentos, sendo os índices catastróficos em torno de $20 \%$ da média anual.

HUECK (1972) considerou que a ocorrência das matas da Serra do Mar seriam decorrentes da grande umidade do ar trazida pelos ventos maritimos que se precipitam sob a forma de chuvas ao subir para altitudes maiores na escarpa.

KRONKA et al. (1993) em levantamento realizado para o Inventário Florestal do Estado de São Paulo, mostraram que a cobertura vegetal natural representa $13,4 \%$ da superfície do Estado, sendo que $4,2 \%$ desta estão concentrados na região do litoral onde se encontra a Serra do Mar.

LIMA et al. (1992) produziram um mapa de riscos de erosão, na escala 1:100.000, em uma área de $190 \mathrm{Km}^{2}$ do sertão da Paraíba, utilizando o Sistema de Informações Geográficas/INPE, onde digitalizaram curvas de nível em 3D, para geração de modelo digital de terreno (MDT), a partir do qual produziram o plano de informação de declividade. Outros planos de informação utilizados foram erodibilidade do solo, erosividade da chuva e cobertura vegetal, a partir de imagens TM-LANDSAT. O mapa resultante contem áreas classificadas com risco de erosão nulo, baixo, moderado, forte e muito forte.

LO \& SHIPMAN (1990), em um estudo para verificação do impacto do desenvolvimento da cidade de Tuen Mun, New Territories, Hong Kong, 
sobre o meio ambiente, usaram como fonte fotografias aéreas dos períodos de 1976 e 1987. Dados complementares foram retirados de mapas topográficos e geológicos, de onde foram extraídas as curvas de nível, declividade, hidrografia, bacias hidrográficas, geologia e rede viária. Numa primeira etapa foi feita a fotointerpretação manual, definindo categorias de uso de solo e gerando um mapa que foi digitalizado juntamente com outros e transformados para o formato raster, utilizando o SIG IDRISI. Concluiram que o SIG foi uma ferramenta poderosa para detectar mudanças de uso do solo, incorporando fotografias aéreas e dados de uso do solo atuais e do passado com outros mapas temáticos.

LUEDER (1959) colocou que o trabalho de campo e a fotointerpretação são inseparáveis, onde, através da convergência de evidências, pode-se chegar a uma eficiente classificação dos tipos florestais.

MACLEAN et al. (1992) através de imagem de satélite LANDSAT TM de 1986 e 1989, mapearam e quantificaram a cobertura vegetal nos dois períodos a fim de avaliar os recursos florestais disponiveis em Lower Penisula, Michigan. Utilizaram o ERDAS GIS, que permitiu a sobreposição dos limites das propriedades sobre as imagens de satélite, uma vez georreferenciadas pelo sistema de coordenadas UTM (Universal Transverse Mercator).

MANTOVANI et al. (1996) analisando o uso de dados de sensoriamento remoto no estudo de escorregamentos, colocaram que, até o momento, este poderia ser considerado inadequado, devido à limitada disponibilidade de fundos e imagens, falta de conhecimento da aplicabilidade dos diferentes tipos de sensoriamento remoto e limitada cooperação entre diferentes tipos de grupos de pesquisa. Geralmente têm sido utilizadas fotografias aéreas em projetos de estudo de escorregamentos e imagens de satélites têm sido usadas em estudos de escorregamentos desde o meio da década de setenta, somente no meio científico. De forma geral o potencial total de capacidade dos dados do sensoriamento remoto não tem sido 
completamente explorados, e este poderia ser usado em várias fases de um estudo de escorregamentos: detecção e classificação, monitoramento, análise e predição no tempo e espaço de falhas nas vertentes. Definiram o termo risco como a probabilidade de ocorrência de um fenômeno potencialmente danoso dentro de um período de tempo específico em uma dada área. Risco de escorregamento tem sido comumente mostrado em mapas que ilustram a distribuição de classes de risco. Zoneamento tem se referido à divisão da terra em áreas homogêneas ou domínios e suas classes de acordo com os graus de risco atual/potencial causado por movimentos de massa, distinguido geralmente em três escalas de análise: regional (1:10.000), média (1:50.000 25.000 ) e grande (> 1:100.000). Ressaltaram que um mapa ideal de risco de escorregamento deveria trazer informações sobre a probabilidade espacial, probabilidade temporal, tipo, magnitude velocidade, distância percorrida e o limite de retrogressão do movimento de massa predito em certa área. A determinação de probabilidades temporais requereria a análise dos fatores desencadeadores do processo, tais como terremotos e chuvas. Entretanto, as classes de legendas usadas na maior parte dos mapas de risco de escorregamento têm dado meramente a informação sobre a suscetibilidade de um terreno para movimentos de massa em termos de alto, médio e baixo risco, sendo todos limitados à probabilidade espacial de ocorrência de escorregamentos. Para os autores, um aspecto importante das técnicas de sensoriamento remoto em estudos de escorregamentos seria uma avaliação do erro e da incerteza, relacionados ao uso de dados existentes, coletas de dados, análises de dados e produção final de mapas de risco. O erro de um mapa só poderia ser avaliado se outro mapa ou informação de campo, livres de erros, fossem com ele comparados. O grau de incerteza estaria fortemente relacionado com a subjetividade de um mapa. O grau de incerteza de alguns fatores está listado abaixo, na Tabela 2. 
Tabela 2. Grau de incerteza de alguns fatores de instabilidade.

\begin{tabular}{ll}
\hline Fator & Grau de incerteza \\
\hline declividade da vertente & baixo \\
\hline orientação da vertente & baixo \\
\hline convexidade da vertente & baixo \\
\hline zoneamento litológico geral & baixo \\
\hline zoneamento litológico detalhado & alto \\
\hline pedologia & baixo/intermediário \\
\hline distribuição da precipitação & intermediário \\
\hline distribuição de movimentos de massa & intermediário \\
\hline uso do solo & baixo \\
\hline
\end{tabular}

Ressaltaram que o mapa de ocorrência de escorregamentos seria de longe o mais importante mapa em um levantamento de risco de escorregamento, uma vez que traz a localização dos escorregamento ocorridos em um passado recente. Além disso, os mapas de risco resultantes poderiam ser comparados com a atual distribuição de escorregamento a fim de checar sua acurácia. A dificuldade seria maior quando predições precisariam ser feitas em área livres de escorregamentos. Nesse caso o pesquisador deveria se basear em modelos que assumem que escorregamentos ocorreriam em locais onde haveria uma combinação de condições que já possibilitaram sua existência no passado. Durante a última década, o desenvolvimento de ferramentas computadorizadas para coleta, armazenamento, exibição e análise de dados espacialmente relacionados dos Sistemas de Informações Geográficas (SIG), possibilitaram a combinação do sensoriamento remoto com outros tipos de produto, tais como, modelos digitais de terreno e outros mapas temáticos. Finalmente, concluíram que fotografias aéreas são a mais importante ferramenta de sensoriamento remoto em estudos de escorregamentos. A aplicação das atuais imagens de satélite, não permite a identificação de feições de falha em vertentes, menores que $100 \mathrm{~m}$, em condições de contraste favorável entre o escorregamento e a informação de fundo, devido sua resolução espacial. Diversos fatores influiriam 
para a incerteza na identificação de escorregamentos, tais como, a experiência do pesquisador em fotointerpretação e conhecimento de campo, o objetivo do estudo, as características da área de estudo, a idade e o tipo dos movimentos de massa, a escala, a qualidade, e o tipo da fotografia aérea utilizada. Quando se trabalha com SIG, erros de digitalização também agravariam essa situação.

MATTOS \& MATSUKUMA (1990) classificaram e mapearam os niveis de degradação da vegetação na Serra do Mar, em Cubatão, através de análise aerofotogramétrica de vôos realizados em 1962, $1972 / 73$ e 1985. Obtiveram três mapas temáticos na escala 1:25.000 referentes à cobertura vegetal nos vales do Mogi e do Cubatão, para os três períodos, sendo o referente a 1985 atualizado com trabalhos de campo em 1988/89. Observaram que no vale do Cubatão, a principal causa da degradação foi o desmatamento, provocado pela construção de vias de acesso e ocupação antrópica ao longo das estradas e na planície fluvial. O vale do Mogi mostrou-se mais degradado, sendo que a perda de espécies devido à poluição atmosférica já mostrava sinais a partir da década de 60 , culminando em 1985, onde em locais onde houve perda total da vegetação, observou-se grande número de movimentos de massa.

MILES \& HO (1999) desenvolveram um protótipo vetorial para SIG para avaliação de risco de escorregamentos provocados por terremotos, usando o método de Newmark. Esse método modelaria um escorregamento sismicamente induzido como um rígido atrito de um bloco sobre um plano inclinado que seria exposto às mesmas acelerações de uma vertente modelada. Calcularia o deslocamento cumulativo de um bloco resultante de um tempo de aceleração. O movimento do bloco ocorreria quando a soma das forças estáticas e dinâmicas excedessem a resistência de cisalhamento do bloco e um valor crítico de aceleração fosse ultrapassado. $O$ primeiro passo desse método seria determinar esse valor crítico de aceleração a partir do qual a vertente sofreria deformação. 
MIRANDA (1990) destacou a importância do geoprocessamento nos estudos na área de análise e monitoramento ambiental, desenvolvidos pela Empresa Brasileira de Pesquisa Agropecuária - EMBRAPA, no seu Núcleo de Monitoramento Ambiental e de Recursos Naturais por Satélites.

MORETTI et al. (1989) colocaram que o conhecimento do comportamento do relevo seria fundamental para a caracterização física regional, e dentre as características do relevo, a declividade seria um parâmetro quantitativo de alta aplicabilidade. A orientação das vertentes em relação aos pontos cardeais, embora pouco utilizada, também seria um parâmetro quantitativo de grande importância, pois estaria diretamente ligada ao balanço de energia na superfície do terreno, e associada com a declividade do terreno permitiria o desenvolvimento de estudos quanto a utilização do solo. A maioria das técnicas de construção de cartas de declividade e orientação de vertentes têm utilizado métodos manuais. Dessa forma utilizaram três métodos, desenvolvidos em um sistema de informação geográfica no formato "raster", para construção de cartas de declividade e orientação de vertentes: maior declividade, vetorial e plano médio. Os três métodos foram comparados aos resultados obtidos por um método manual. Também foram estudados o efeito do tamanho das quadrículas na classificação da declividade. Obtiveram uma correlação positiva entre os resultados dos métodos digitais com o manual, para declividade e orientação de vertentes, porém, o método vetorial produziu resultados mais próximos aos do método manual, sendo indicado para sua substituição. As quadrículas de $150 \mathrm{~m}$, foram mais adequadas para o cálculo simultâneo de declividade e orientação de vertentes. De forma geral concluíram que os métodos digitais foram mais consistentes que o método manual, pois estes minimizaram a variação causada pela subjetividade do método manual.

NALON \& VELLARDI (1993) verificaram em estudos hidrológicos no vale do rio Pilões, Cubatão, que as estações chuvosas estão divididas em um período muito chuvoso (de outubro a março) responsável em média por 
$65 \%$ da precipitação anual, período chuvoso (abril, maio e setembro) responsável em média por $23 \%$ da precipitação anual e período pouco chuvoso (de junho a agosto) responsável em média por $12 \%$ da precipitação anual.

PERALTA (1990), na elaboração de um modelo digital para determinar áreas de riscos de escorregamentos, utilizando o Sistema de Análise Geo-Ambiental - SAGA no entorno do reservatório de Itacoara - RJ, considerou os parâmetros declividade, altimetria, cobertura vegetal, geologia, solos e um mapa de informações básicas de uso do solo. Como mapa de referência utilizou cartas topográficas do IBGE na escala 1:50.000. Para cada parâmetro atribuiu um peso de acordo com sua importância para estimar os riscos de escorregamentos, de forma que a soma desses pesos fosse $100 \%$. Para declividade foi atribuído o peso $40 \%$, para o solo $15 \%$, geologia $10 \%$, vegetação $10 \%$, altimetria $15 \%$ e uso do solo $10 \%$. Como produto obteve uma carta de risco de escorregamentos classificada em risco muito baixo, baixo, alto e muito alto.

POLEMIO \& SDAO (1999) estudaram o papel da precipitação no risco de escorregamentos, na uma área urbana de Avigliano, Itália. Esta área foi palco de severos movimentos de massa, com uma variedade de mecanismos deflagradores, tais como terremotos, chuvas fortes periódicas e enchentes, atingindo áreas urbanizadas. Basearam-se nas características geológicas e geomorfológicas dos escorregamentos e no levantamento da precipitação acumulada em períodos de 1 até 180 dias anteriores a ocorrência desses eventos. Comentaram que pesquisadores têm sido cuidadosos em assumir que a precipitação é a causadora na instabilidade de uma vertente, mesmo quando esse fenômeno ocorre concomitantemente com chuvas fortes. A precipitação pode ser a única causa de instabilidade de vertentes somente quando é excepcionalmente forte. O método sugerido pelo autores, visou identificar a duração crítica, em número de dias consecutivos, durante a qual uma chuva pode causar escorregamentos, sobre uma dada condição climática 
e geomorfológica. Concluíram que a precipitação acumulada entre 10 e 90 dias consecutivos foi relevante na ocorrência de escorregamentos em Avigliano.

QUEIROZ NETO \& KUPPER (1965) em um estudo de mapeamento dos solos da Serra do Cubatão, apresentaram uma interligação em função das limitações de uso. Concluíram que no que diz respeito ás características do solo, a maior parte da área estudada incluiu-se na classe "áreas não utilizáveis" correspondendo os Podzóis hidromórficos, em trechos da baixada litorânea e os Latossolos e Litossolos da Serra do Mar, recomendando serem "destinados às atividades florestais".

No PROGRAMA SERRA DO MAR (1987) foi produzida uma carta de declividade para as encostas da Serra do Mar, região de Cubatão, utilizando quadrículas de $250 \mathrm{~m}$ sobre base topográfica IBGE na escala 1:50.000, com classes de declividade baseadas no trabalho de CRUZ (1975). A área da região estudada foi de $43.487,5$ ha. Levantaram que $36,7 \%$ da área está na classe $\left(0^{\circ}-13^{\circ}\right), 45,5 \%$ na classe $\left(14^{\circ}-25^{\circ}\right), 15,6 \%$ na classe $\left(26^{\circ}\right.$ $\left.35^{\circ}\right), 2,1 \%$ na classe $\left(36^{\circ}-45^{\circ}\right)$ e $0,1 \%$ na classe $\left(>45^{\circ}\right)$.

RIZZINI (1979) localizou a ocorrência da Floresta Latifoliada Tropical Úmida de encosta ou Mata Tropical Atlântica sobre a cadeia litorânea, que ocorre ao lado do Oceano Atlântico, desde o Rio Grande do Sul até o Nordeste.

ROSA (1995) apresentou uma proposta metodológica para o zoneamento de bacias hidrográficas utilizando produtos de sensores remotos e documentos cartográficos através de um sistema de informações geográficas e uma avaliação de sua aplicação, em uma sub-bacia hidrográfica do ribeirão Douradinho, MG. Utilizou o sistema de informações geográficas GRASS e os mapas temáticos de solos, uso da terra, declividade, relevo, perdas de solo, densidade de voçorocas, substrato rochoso, hipsometria e aptidão das terras para fins agrícolas. Através do cruzamento desses mapas, utilizando operadores lógicos AND e OR, identificou oito categorias de zoneamento 
compreendendo diferentes aptidões ao uso agrícola, unidades de preservação e áreas urbanizadas. Destacou as vantagens do uso do sistema de informações geográficas, tais como redução da subjetividade em operações de cruzamento manual de informações, rapidez na sobreposição de mapas temáticos e cálculo de áreas, possibilidade de obtenção de mapas temáticos derivados e facilidades de atualização e aperfeiçoamento de diagnósticos com a alimentação de novos dados.

ROSSI et al. (1991) em estudos pedológicos realizados no Parque Estadual da Serra do Mar, na região de Cubatão, constataram que os solos predominantes na área são Cambissolos $(\mathrm{Ca})$, solos em formação e pouco profundos; os Latossolos (LVa), solos desenvolvidos e com boa drenagem interna; os Litossolos ( $\mathrm{Ra}$ ), solos rasos com menos de $0,40 \mathrm{~cm}$ de profundidade e os Podzólicos, compostos por um horizonte B textural mais argiloso e um horizonte superficial com menor teor de argila. Como produto obtiveram um mapa de solos da região (ROSSI \& PFEIFER, 1991).

SKIDMORE et al. (1991) no desenvolvimento de um sistema especializado para mapeamento de solos florestais em uma floresta nativa de eucalyptus no sudeste da Austrália, usaram como base a imagem do satélite LANDSAT Thematic Mapper, a partir da qual foram identificadas cinco unidades de solos florestais e produzidos os mapas temáticos de classes de eucalyptus nativo, declividade e indicadores de umidade do solo, sendo os dois últimos gerados a partir de modelo digital do terreno. Os mapas temáticos foram convertidos para o formato raster em grade de $30 \mathrm{~m} \times 30 \mathrm{~m}$ em um Sistema de Informações Geográficas. As regras do sistema especializado foram provenientes do conhecimento de um especialista em solos sobreposto aos mapas temáticos no SIG. Estas regras puderam se originar estatisticamente, em uma situação ideal que freqüentemente não ocorreria, ou subjetivamente, pois eram relações do meio ambiente que não puderam serem expressas com absoluta certeza, e foram expressas na forma de 
probabilidades. O mapa gerado por esse sistema foi comparado com levantamentos de campo e este mostrou-se com uma precisão de $66,7 \%$. Segundo os autores, erros nos mapas temáticos reduziram a precisão do sistema especialista.

SOUZA (1990) utilizou um sistema de informações geográficas para o planejamento de rede viária e o zoneamento do Parque Estadual do Rio Doce, Minas Gerais, elegendo nove modalidades de uso do solo do parque, gerando para cada uma destas, um mapa de oportunidades e um mapa de restrições a partir de mapas de levantamentos básicos de fauna, vegetação, solos, recursos hídricos, declividade, exposição solar e qualidade visual. De acordo com o tipo de uso, cada mapa básico recebeu um atributo que correspondeu a um peso de importância baseado nas facilidades e dificuldades técnicas, ecológicas e econômicas para a implantação do objetivo proposto. A adequação de uma área para determinada atividade foi definida pelo critério de que essa área deveria oferecer maiores oportunidades e menores restrições.

SPURR (1969) verificou que para a fotointerpretação de áreas que apresentam uma vegetação de composição e estrutura complexa, é necessário que o fotointérprete esteja familiarizado com a ecologia da região a ser estudada, através de observações de campo e apoiado em literatura existente.

TEIXEIRA et al. (1990) através do sistema de informação geográfica Geo-Inf/Map, desenvolvido pela UNESP - Rio Claro, mapearam as áreas de risco à erosão laminar na bacia do córrego do Monjolo na Área de Proteção Ambiental Corumbataí, São Paulo. Utilizaram como material cartográfico cartas topográficas do IBGE na escala 1:50.000, mapa pedológico na escala 1:100.000, mapa de uso da terra na escala 1:35.000, mapa de declividade e mapa geomorfológico. Todos os dados foram transferidos para a escala 1:50.000, e convertidos para o formato raster, com uma grade de células quadrada regular de $250 \mathrm{~m}$ de lado. A partir do levantamento de dados 
pluviométricos locais, estimaram o parâmetro erosividade e também utilizaram os parâmetros erodibilidade e fator topográfico, que dependem do comprimento e declividade da vertente. Finalmente, obtiveram um mapa de suscetibilidade à erosão laminar que correlacionado ao mapa de uso da terra, gerou um mapa das áreas de risco à erosão laminar com as categorias baixa, média e alta.

Para TEIXEIRA \& GERARDI (1992) cartas de declividade e exposição de vertentes têm permitido a obtenção de informações diretas sobre o relevo e têm sido freqüentemente produzidas por métodos manuais, que consomem muito tempo para sua execução. Na carta de orientação de vertentes, procura-se definir o plano que melhor se adapte a uma porção do terreno, sendo o azimute desse plano a exposição do terreno. Dentre as técnicas computacionais atuais, destacaram os Sistemas de Informações Geográficas, onde as cotas do terreno armazenadas em meio digital são utilizadas para a construção do modelo numérico do terreno que permite a visualização tridimensional e bidimensional para estudos de declividade e orientação de vertentes. O terreno seria dividido em quadrículas regulares que generalizariam a informação do seu interior, logo, o tamanho da quadrícula seria diretamente proporcional ao grau de generalização. Propuseram um algoritmo para a construção automática da carta de declividade, utilizando-se o centro médio e o centro médio ponderado das quadrículas, que foi testado em uma superfície esférica e em outra elíptica, obtendo $100 \%$ de acerto em ambos. Ressaltaram que as irregularidades do terreno, não representadas pelas quadrículas, levaram a uma perda de eficiência do modelo computacional, e aplicando o algoritmo em uma porção real de terreno e comparando a carta de declividade produzida pelo método computacional com a carta produzida por um método manual, obtiveram um ajustamento de $78,5 \%$ entre os métodos, creditando o percentual de não-coincidência basicamente a irregularidades do terreno não absorvidas pelo tamanho da quadrícula e a subjetividade do método manual. 
TEUBNER JUNIOR (1993) na elaboração de um modelo para zoneamentos ambientais costeiros utilizou o sistema de informaçōes geográficas SPANS, na região da Grande Vitória, ES, e as cartas temáticas planialtimétrica/batimétrica, clinográfica, climática, geológica/faciológica, geomorfológica, solos, qualidade e disponibilidade das águas, parâmetros oceonográficos, recursos biológicos, uso e cobertura atual, socioeconômica e zoneamentos existentes. Propôs a elaboração de um macrozoneamento com a utilização de um menor número de planos de informações sem comprometimento de sua qualidade, utilizando a ferramenta estatística de coeficientes quadrados para avaliar o ajuste entre dois planos de informações. Comparou então, três cartas de macrozoneamento, da mesma área, produzidas por metodologia convencional, de acordo com modelo proposto pela UERJ e gerada pelo modelo de supressão de informações. Concluiu que o número de planos de informação podem ser reduzidos de 22 para 16, obtendo-se consideráveis semelhanças entre o produto gerado por meio convencional e o obtido pelo meio digital, possibilitando a elaboração de zoneamentos ambientais de boa qualidade para regiões onde não existam todas as informações necessárias para o uso da metodologia convencional atualmente adotada, reduzindo custos o rápida obtenção de resultados.

TOMIDA (1990) descreveu um plano mestre para trabalhos de prevenção de desastres provocados por movimentos de massa, utilizando técnicas de $\mathrm{SABO}$, na região de Cubatão, $\mathrm{SP}$. Levantou que nos últimos 30 anos, os maiores eventos de movimento de massa ocorreram a cada 5 a 10 anos, quando das fortes chuvas de novembro a abril, sendo em número de 40 em 1962, 218 em 1971, 303 em 1976, 187 em 1980, 905 em 1985 e 215 em 1988. Em relação à declividade das vertentes, a taxa de ocorrência de movimentos de massa foi de $1,6 \%$ em vertentes declividade menor que $20^{\circ}$, $18,2 \%$ entre $20^{\circ}$ e $30^{\circ}, 32,9 \%$ entre $30^{\circ}$ e $40^{\circ}$ e $48,3 \%$ em declividades superiores a $40^{\circ}$. 
TROPPMAIR \& FERREIRA (1987) descreveram que pela proximidade ao porto de Santos, instalou-se em Cubatão um complexo industrial, composto de siderúrgicas, metalúrgicas, e na maior parte indústrias químicas, podendo ser citadas: CARBOCLORO, CIA. SANTISTA DE PAPEL, CIMERITA, CLOROGIL, COPEBRÁS, COSIPA, ENGECLRO, ESTIRENO, LIGHT, RPBC, PETROQUISA, ULTRAFERTIL, UNION CARBIDE, ADUBOS TREVO, CIA. PETROQUÍMICA BRASILEIRA, IAPT INDÚSTRIA DE FERTILIZANTES, MANAH, RHODIA E SOLORRICO FER. UNIÃO. Estudando a correlação entre escorregamentos, poluição aérea e cobertura vegetal na Serra do Mar, Cubatão, levantaram que nos anos de 1973, 1981 e 1985, foram registrados, na região, escorregamentos em números de 165, 257 e 525 respectivamente, sendo que em sua grande maioria possuiam uma extensão entre 25 e $175 \mathrm{~m}$. Quanto à vegetação dessa região, seu sistema radicular é superficial, com um raio que varia de 10 a 40 m, devido à ocorrência de solo rasos e encharcados e lençol freático próximo à superfície e dada a distância média entre árvores de 12 a $15 \mathrm{~m}$, criou-se uma malha radicular contínua que estabiliza a camada de solo. Observaram que o conjunto das caracteristicas ambientais: vegetação densa com cobertura contínua, sistema radicular denso, entrelaçado e superficial, escoamento de água pelo tronco lento e ocorrência de camada de húmus, seria responsável pela estabilidade das encostas da Serra do Mar, e quando os ventos predominantes de sudeste carregam os poluentes na direção da encosta da Serra do Mar, aprisiona-os nos vales do Mogi e Quilombo, resultando em grandes áreas de degradação com a morte de indivíduos ou de toda a mata. Nesse momento o sistema torna-se instável, desencadeando a ocorrência de escorregamentos.

TURRINI (1998) propôs um método numérico-cartográfico que permitiu a divisão preliminar das áreas com risco de escorregamento, que consistiu na construção de vários mapas temáticos que representavam fatores de predisposição a escorregamentos. Esses mapas foram divididos em áreas 
homogêneas com atribuição de valores entre 0 e 2 , de acordo com sua influência. $O$ fato de todos os fatores terem o mesmo valor máximo significou que cada um deles foi considerado um fator de predisposição. Os mapas de cada fator foram sobrepostos e somados gerando novos mapas parciais. $O$ mapa resultante continha muitas micro-facetas cujo valor representa a influência total dos fatores considerados, naquela porção da vertente. Este mapa foi reclassificado para melhor visualização das zonas de risco de escorregamento: muito baixo, baixo, moderado, alto e muito alto. Os mapas temáticos utilizados foram os de erodibilidade, permeabilidade, estrutura, declividade de vertente e uso do solo. Concluiu que o mapa de risco de escorregamento gerado deu uma visão precisa da região estudada, podendo o método ser aplicado em regiões vizinhas que tivessem formações litoestratigráficas e morfológicas semelhantes e que o mapa final poderia ser facilmente interpretado por um técnico não especializado.

WESTMORELAND \& STOW (1992) utilizaram o sistema ERDAS/ARC-INFO para interpretação de imagens de satélite, análise e armazenamento de dados de uso do solo a fim identificar áreas com mudanças no uso do solo na região de San Diego, EUA. Desenvolveram um programa usando ARC MACRO LANGUAGE (AML) para a interpretação das categorias de uso do solo que sofreram alterações, criando um polígono em torno das mesmas e associando o novo uso. O sistema identificou corretamente $70 \%$ dos polígonos e $75 \%$ da área total, o que estaria abaixo da precisão mínima esperada para aplicações de planejamento urbano para mapas de uso e cobertura do solo, que é de $85 \%$. Concluíram que apesar do programa requerer melhor refinamento, o uso integrado de SIG e processamento de imagem deu ao intérprete visual maior eficiência. 


\section{MATERIAL E MÉTODOS}

No mapeamento do risco de escorregamentos, proposto nesse estudo, foram utilizadas duas ferramentas principais. Uma foi a tecnologia de sistemas de informações geográficas (SIG), para o processamento e a análise de dados, e outra foi um método indireto estatístico, para a construção de um modelo de avaliação de risco de escorregamento.

\section{1 Área de estudo}

A região selecionada para esse estudo localiza-se no Parque Estadual da Serra do Mar, SP, entre as coordenadas $23^{\circ} 45^{\prime}$ e $24^{\circ} 00^{\prime}$ de latitude

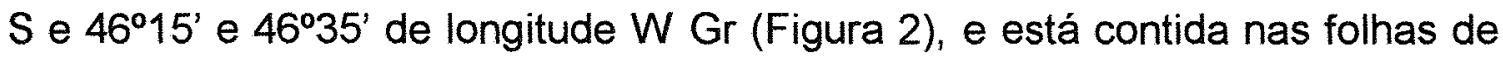
Santos e Riacho Grande, do IBGE, na escala 1:50.000, que foi a escala adotada com base deste estudo. Compreende os vales do rio Mogi, rio Perequê, parte dos vales do rio Pilões e rio Cubatão.

Alguns mapas temáticos utilizados, cobriram extensões diferentes da região estudada. A área de estudo considerada, foi aquela onde houve coincidência em todos os mapas temáticos utilizados. Possui uma superfície de $10.706,9$ ha e está compreendida entre as coordenadas UTM 346.000E e $374.0000 \mathrm{E}, 7.352 .000 \mathrm{~N}$ e $7.370 .000 \mathrm{~N}$. 


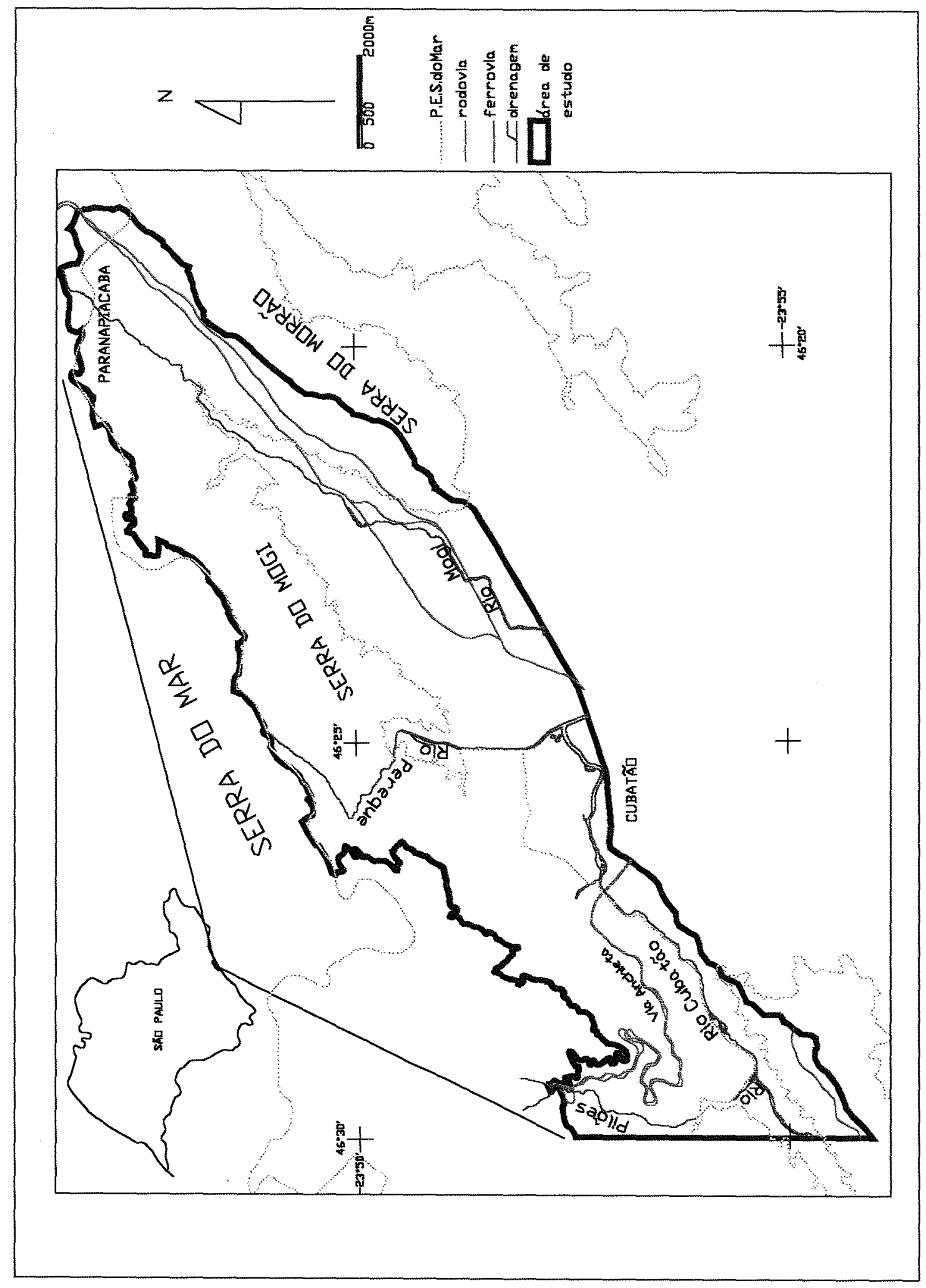

Figura 2- Mapa de localização da área de estudo. 
Somente os resultados dos cruzamentos dos mapas temáticos contidos dentro dessa área foram considerados para análise final.

O contorno da área de estudo foi utilizado como uma máscara, que foi sobreposta a cada mapa temático, recortando a área de interesse. Esse procedimento, visou além de destacar a área de estudo da região de entorno, otimizar as análises, reduzindo a área.

\subsection{Tecnologia de sistema de informações geográficas (SIG)}

A utilização da tecnologia de sistema de informações geográficas requer que os dados espaciais e não espaciais estejam no formato digital.

Dados espaciais são elementos definidos por variáveis espaciais $x, y \in z$, e estão relacionados a um determinado sistema de coordenadas, no presente caso a Universo Transverso de Mercator (UTM). Dados não espaciais são constituídos de atributos alfa-numéricos que descrevem características dos dados espaciais, geralmente armazenados em tabelas e relacionados aos mesmos através de uma chave identificadora.

A representação digital de dados espaciais pode ser feita, basicamente, no formato vetorial ou no formato raster.

A representação vetorial está baseada em pontos, linhas e polígonos de um espaço contínuo, segundo os postulados da geometria euclidiana. Os valores de coordenadas de seus pontos são matematicamente exatos. Tenta reproduzir um elemento da forma mais exata possivel, conforme TEIXEIRA et al. (1992). Pode-se citar como vantagens do formato vetorial sua estrutura de dados compacta, possibilidade de codificação de topologia, representação próxima de desenhos feitos a mão, eficiência para a recuperação e atualização de gráficos e atributos, rapidez em operações 
gráficas de visualização. Como desvantagens: as dificuldades nas operações de superposição, representação de alta variabilidade espacial não eficaz, requer tecnologia sofisticada e cara, dificuldade em operações de modelagem espacial.

A representação raster, também conhecida com matricial, tem o espaço representado por uma grade de células, integradas com um sistema de coordenadas. Cada célula possui um par de coordenada espaciais $x, y$ e um valor $z$ que se refere a um atributo da mesma. Sua representação se dá através de uma superfície discreta. Como vantagens do formato raster, pode-se citar a estrutura simples dos dados, facilidade para operações de superposição, eficiência na representação de alta variabilidade espacial, precisão em operações matemáticas, requer tecnologia barata, e facilidade para operações de modelagem espacial. Como desvantagens o espaço muito extenso que ocupa para armazenamento, dificuldade de representar relações topológicas, dificuldades para análises de redes, o uso de grandes células para reduzir o volume de dados pode significar generalização de estruturas, transformações de projeção são demoradas.

O sistema de informação geográfica utilizado nesse trabalho foi composto pelo conjunto de programas ArcCad, ArcView GIS e o ArcView Spatial Analyst, para ambiente WINDOWS98, em microcomputadores PC. Possui interface com Arclnfo e permitiu a importação de arquivos vetoriais gerados nos principais softwares CAD e de arquivos raster em diversos formatos, além de ferramentas para visualização, exploração, questionamento e análise de dados geográficos. Dados tabulares puderam ser adicionados a partir de arquivos dBASE e outros formatos. Entre as operações possiveis dentro desse SIG, destacaram-se a medida de distâncias, medida de áreas, álgebra de mapas, operações booleanas, conversão de formatos vetorial para raster e vice-versa, geração de modelos digitais do terreno (MDT) e seus 
produtos tais como, mapa de declividade, orientação de vertente e perfil de terreno.

\subsubsection{Unidade de terreno}

Unidade de terreno é uma porção da superfície da terra que contém um conjunto de condições de terreno que diferem de outras unidade adjacentes ao longo de fronteiras definidas.

A utilização de SIG's que suportam dados em formato raster, ou matricial, implica na divisão do terreno em uma grade de células de um dado tamanho, que se tornam as unidades de terreno.

A unidade de terreno adotada nesse trabalho foi uma grade regular de células de tamanho $30 \mathrm{~m} \times 30 \mathrm{~m}$. Esse tamanho de célula foi compativel com a escala da base cartográfica adotada, que foi a de 1:50.000 das cartas do IBGE, onde a espessura de uma linha de $0,3 \mathrm{~mm}$ eqüivale a 15 $\mathrm{m}$. Nessa escala a grade de células adotada eqüivaleu a $0,6 \mathrm{~mm} \times 0,6 \mathrm{~mm}$, ou seja, foi maior que a menor espessura de linha encontrada na base cartográfica. Os erros médios quadráticos aceitos na conversão do material no formato analógico para o formato digital das outras escalas utilizadas nesse trabalho basearam-se nesta mesma equivalência de espessura de linha.

Definida a unidade de terreno, todas as análises subseqüentes referiram-se e trataram, cada unidade de terreno, como um domínio espacialmente homogêneo em termos de características de fatores de instabilidade e grau de risco de escorregamento. 


\subsubsection{Conversão de dados do formato analógico para formato digital}

Os documentos cartográficos que geraram os mapas temáticos utilizados nesse estudo, estavam originalmente no formato analógico, ou seja, sobre base de papel ou filme.

A conversão desse material do formato analógico para o formato digital, ocorreu de duas formas, sendo elas:

- entrada de dados via mesa digitalizadora, que permitiu a geração automática de arquivos de formato vetorial, e

- entrada de dados via scanner, que permitiu a geração automática de arquivos de formato raster.

$\mathrm{Na}$ entrada de dados, via mesa digitalizadora, o software do tipo CAD (Computer Aided Design) utilizado foi o AUTOCAD. Este, permitiu a representação precisa de feições do tipo ponto, arco e poligono, utilizando o sistema de projeção cartográfica UTM (Universal Transversa de Mercator) como sistema de coordenadas.

No caso de entrada de dados via scanner, o arquivo raster gerado, foi exportado para o software Microstation/IRAS-C, também do tipo CAD. Este permitiu que 0 arquivo raster fosse ajustado ao sistema de projeção cartográfica UTM, tivesse suas feições vetorizadas manualmente e depois fosse exportado para o AUTOCAD.

Durante o processo de conversão dos dados para o formato digital, os error médios quadráticos máximos aceitos, foram de 15 metros para escala 1:50.000, 7,5 metros para escala 1:25.000 e 300 metros para a escala 1:100.000.

Todos arquivos vetoriais finais, com os atributos correspondentes, foram produzidos no AUTOCAD.

No caso de arquivos com tema representado por polígonos, os atributos foram números, que representaram as classes componentes dos 
mesmos, inseridos dentro de cada poligono. Nos arquivos com tema representado por linhas, os atributos foram valores de coordenada $z$, além das coordenadas $x, y$ que representaram os vértices dessas linhas.

\subsubsection{Tipos de arquivos para uso em SIG}

O SIG utilizado, ArcView GIS e Spatial Analyst, possui ferramentas para processamento e análise de dados no formato vetorial e no formato raster, permitindo também a conversão entre esses formatos.

No caso dos arquivos vetoriais, esses tiveram sua topologia verificada e construída. Os arquivos raster também foram colocados em formato adequado para sua importação.

Os arquivos que tiveram sua entrada no formato vetorial foram os referentes aos mapas temáticos de pedologia, cobertura vegetal, morfologia, litologia, e os mapas das áreas com escorregamentos e áreas sem escorregamentos.

Os arquivos que tiveram sua entrada no formato raster foram os modelos numéricos referentes ao modelo digital de terreno (MDT), modelo digital da precipitação média do trimestre mais chuvoso e do modelo digital da precipitação média total anual.

\subsubsection{Construção de topologia dos arquivos vetoriais para uso em SIG}

Após a conversão dos dados para o formato vetorial foi feita a construção da topologia dos mesmos.

Topologia é a parte da matemática que concerne às propriedades geométricas que são independentes de uma distância métrica e são constantes 
sob qualquer distorção contínua, como rotação ou mudança de escala. Em cartografia, topologia refere-se à topologia combinatória, ou seja, as características dos objetos geométricos que não dependem de medições em um sistema de coordenadas. As relações topológicas entre dois objetos podem ser de disjunção, adjacência, contingência, igualdade, adjacência e contingência, intersecção e cruzamento.

Nesse processo foi utilizado o software ArcCAD, que é um sistema de informações geográficas desenhado para o AUTOCAD, onde os três principais conceitos topológicos são:

- arcos que se conectam ao redor de uma área definem um polígono, ou seja, definição de área.

Polígonos podem ser representados topologicamente com os arcos que definem um polígono, bem como por um laço fechado de coordenadas $x, y$. A lista de arcos que compõem cada polígono é armazenada e usada para construir o polígono quando necessário. Um arco pode estar na lista de arcos de dois polígonos diferentes, mas suas coordenadas são armazenadas uma única vez, reduzindo a quantidade de dados e evitando que fronteiras de polígonos adjacentes se sobreponham.

- arcos têm direção, e lados esquerdo e direito, ou seja, contigüidade.

Polígonos que partilham um arco em comum são adjacentes. Por isso cada arco possui uma direção, do-nó e para-o-nó, e uma lista dos polígonos a esquerda e a direita do arco pode ser mantida.

- arcos conectam-se uns aos outros por nós, ou seja, conectividade.

Os pares de coordenadas $x, y$ ao longo de um arco, chamados vértices, definem a forma do arco. Os pontos finais do arco são chamados nós. Portanto cada arco possui dois nós, através dos quais outros arcos podem se juntar.

Uma vez verificados os conceitos topológicos, é gerada para cada mapa temático, uma tabela de atributos de feição (FAT), que é um arquivo de 
dados gerado e manipulado pelo ArcCAD, que armazena as identificações das feições e seus atributos, no formato dBASE. Nesse estudo, todos os mapas vetoriais, submetidos a essas condições, são constituídos por polígonos. Nesse caso a FAT gerada tem o nome específico de PAT (Polygon Attribute Table ou Tabela de Atributos de Polígonos), onde cada polígono possui um registro nos itens mostrados na Tabela 3.

Tabela 3. PAT (Polygon Attribute Table ou Tabela de Atributos de Polígonos).

\begin{tabular}{|c|c|c|c|c|c|}
\hline $\begin{array}{c}\text { NÚMERO } \\
\text { DO } \\
\text { REGISTRO }\end{array}$ & ÁREA & PERÍMETRO & $\begin{array}{c}\text { NÚMERO } \\
\text { NÚMERO } \\
\text { INTERNO }\end{array}$ & $\begin{array}{c}\text { DO } \\
\text { USUÁRIO }\end{array}$ & ATRIBUTO \\
\hline
\end{tabular}

- número do registro: um único valor numérico é assinalado para cada linha da tabela; esse item aparece na listagem da tabela mas não faz parte dela.

- área: a área de cada polígono é assinalada nesse item.

- perímetro: o perímetro de cada polígono é assinalado nesse item.

- número interno: contém um único número identificador assinalado pelo ArcCAD; estes números iniciam por 1 e são seqüenciais.

- número do usuário: contém um número assinalado pelo usuário.

- atributo: também contém caracteres assinalados pelo usuário, que podem ser alfa-numéricos, e descrevem alguma característica da feição.

Os arquivos produzidos pelo ArcCad são denominados "coverages", que é o formato vetorial do Arclnfo. O ArcView Spatial Analyst leu esses arquivos, convertendo-os para seu formato vetorial que é denominado "shape". 


\subsubsection{Arquivos raster baseados em modelos numéricos}

Modelos numéricos foram gerados a partir de algoritmos matemáticos e representam numericamente a distribuição espacial de uma variável dependente $z$ em função de variáveis independentes $x, y$.

Esses modelos representam superfícies em três dimensões. Conceitualmente, superfícies implicam em uma distribuição contínua de um atributo sobre uma região bidimensional, tendo um único valor em cada ponto, entretanto, do ponto de vista topológico, uma superfície é simplesmente um plano deformado em três dimensões.

Normalmente, o que temos é uma amostragem de pontos isolados, sobre uma superfície contínua, que tem seus valores medidos e através dos quais desejamos representar a superfície de origem. Para tanto, vários métodos de interpolação podem ser aplicados. A interpolação é um processo para determinar o valor de um atributo contínuo em um local intermediário entre pontos conhecidos. Como produto podemos obter um modelo digital de elevação, também conhecido como matriz digital de elevação, que é uma estrutura matricial com medidas de elevações regulares e controladas espacialmente.

O modelo digital de terreno (MDT) foi construído a partir das curvas de nível digitalizadas no AUTOCAD, onde foi gerado um arquivo contendo uma massa de pontos identificados por três coordenadas $(x, y, z)$, sendo $x$ e $y$ as coordenadas UTM (N, E) e $z \circ$ valor da altitude, todos em metros. Esse arquivo foi importado pelo Surfer, que é um software especialista na geração de modelos digitais. Neste, foi aplicado um interpolador para geração da grade de células que representa a superfície do terreno da área de estudo. O método de interpolação aplicado foi o de "inverso da distância ao quadrado", que é um interpolador de médias ponderadas, onde o peso dado a um dado em particular, para o cálculo do valor de um nó da grade, é 
proporcional ao inverso de sua distância ao quadrado do mesmo até o nó. Os pesos têm valores fracionários, em relação a um mesmo nó, e sua soma é igual a 1,0 . Quando um ponto coincide com o nó, recebe o peso 1,0 e os demais, peso 0,0. A forma de busca dos dados, em torno de um nó, foi feita por quadrante, ou seja, com busca de $n$ vizinhos dentro de um quadrante.

Da mesma forma, os modelos digitais da precipitação média do trimestre mais chuvoso e da precipitação média total anual foram construídos a partir das isoietas de precipitação referentes a cada um, que após serem digitalizadas geraram dois arquivos de pontos identificados por três coordenadas $(x, y, z)$, onde $x, y$ eram as coordenadas UTM (N, E) e $z$ representou a altura média de precipitação, em milímetros. $O$ mesmo método de interpolação aplicado na construção do MDT, foi aplicado nesses dois modelos.

\subsubsection{Conversão vetor-raster}

Nessa etapa, tanto os modelos digitais de elevação como os arquivos vetoriais, foram transferidos para o ArcView Spatial Analyst, onde foram todos convertidos para o formato "grid", que é o seu formato de arquivo raster. Todos os mapas temáticos passaram, então, a serem representados por uma grade de células de tamanho $30 \mathrm{~m} \times 30 \mathrm{~m}$, que foi a unidade de terreno adotada. 


\subsection{Mapas temáticos}

Os mapas temáticos utilizados, referem-se aos fatores de instabilidade considerados para a avaliação do risco de escorregamento em cada unidade de terreno da área de estudo.

\subsubsection{Modelo digital de terreno (MDT) e seus produtos}

O material base para a produção desse mapa foram as cartas topográficas do IBGE, na escala 1:50.000, Riacho Grande (folha SF.23-Y-C-VI4) e Santos (folha SF.23-Y-D-VI-3 / SG.23-V-B-I-1 MI-2794-3 / MI-2815-1).

A área abrangida por esses mapas está compreendida entre as coordenadas UTM 336.000E e 368.0000E, 7.7345.000N e 7.737.000N, compreendendo uma superfície de 80.000 ha. Dentro dessa área estão contidos os vales do Mogi, Cubatão, Perequê, Pilões, parte do Quilombo e parte do Jurubatuba, abrangendo os municípios de Santos, Guarujá, São Vicente, Cubatão, Praia Grande, São Bernardo do Campo e Rio Grande da Serra. O mapa topográfico foi composto das curvas de nível com eqüidistância de $20 \mathrm{~m}$. O valor mínimo de altitude nesse mapa foi 0 (zero) metro e o máximo foi de 1.080 metros, próximo a Paranapiacaba.

Os valores de altitude do terreno foram agrupados em classes hipsométricas que representaram três compartimentos das vertentes escarpadas, que são baixa, média e alta encosta, representados no mapa hipsométrico (ANEXO A), conforme a Tabela 4. 
Tabela 4. Classes hipsométricas.

\begin{tabular}{|c|c|}
\hline Classe & Descrição \\
\hline $0 \mathrm{~m}-100 \mathrm{~m}:$ & baixa encosta \\
\hline $100 m-300 m:$ & baixa encosta \\
\hline $300 m-500 m:$ & média encosta \\
\hline $500 m-700 m:$ & alta encosta \\
\hline $700 m-900 m:$ & alta encosta e planalto \\
\hline$>900 \mathrm{~m}:$ & alta encosta \\
\hline
\end{tabular}

Os mapas clinográfico e de exposição de vertentes foram gerados através de ferramentas para geração automática desses mapas a partir do modelo digital de terreno, contidos no ArcView Spatial Analyst.

\subsubsection{Mapa clinográfico}

O mapa clinográfico (ANEXO B), teve seus valores agrupados em classes baseadas em DE BIASI (1992), CRUZ (1975), conforme Tabela 5.

Tabela 5. Classes clinográficas.

\begin{tabular}{|r|l|}
\hline \multicolumn{1}{|l|}{ Classe } & Descrição \\
\hline $0^{\circ}-7^{\circ}$ & $\begin{array}{l}\text { engloba os limites máximos urbano-industrial, e do emprego } \\
\text { de mecanização agrícola }\end{array}$ \\
\hline $7^{\circ}-17^{\circ}$ & engloba o limite máximo para urbanização sem restrições \\
\hline $17^{\circ}-25^{\circ}$ & engloba o limite máximo de corte raso \\
\hline $25^{\circ}-36^{\circ}$ & $\begin{array}{l}\text { dentro dessas classes não é permitida a derrubada de } \\
\text { florestas }\end{array}$ \\
\hline$>45^{\circ}$ & vertentes de maior declividade das escarpas da Serra do Mar \\
\hline
\end{tabular}




\subsubsection{Mapa de exposição de vertentes}

O mapa de exposição de vertentes (ANEXO C) teve seus valores agrupados em classes definidas pelo octante, de acordo com MORETTI et al. (1989) e DE BIASI et al. (1977), conforme Tabela 6.

Tabela 6. Classes de exposição de vertentes.

\begin{tabular}{|l|l|l|}
\hline Classe & De & Até \\
\hline $\mathrm{N}$ (norte) & $337^{\circ} 30^{\prime}$ & $22^{\circ} 30^{\prime}$ \\
\hline NE (nordeste) & $22^{\circ} 30^{\prime}$ & $67^{\circ} 30^{\prime}$ \\
\hline L (leste) & $67^{\circ} 30^{\prime}$ & $112^{\circ} 30^{\prime}$ \\
\hline SE (sudeste) & $112^{\circ} 30^{\prime}$ & $157^{\circ} 30^{\prime}$ \\
\hline S (sul) & $157^{\circ} 30^{\prime}$ & $202^{\circ} 30^{\prime}$ \\
\hline SO (sudoeste) & $202^{\circ} 30^{\prime}$ & $247^{\circ} 30^{\prime}$ \\
\hline O (oeste) & $247^{\circ} 30^{\prime}$ & $292^{\circ} 30^{\prime}$ \\
\hline NO (noroeste) & $292^{\circ} 30^{\prime}$ & $337^{\circ} 30^{\prime}$ \\
\hline
\end{tabular}

\subsubsection{Mapa pedológico}

Utilizou-se a carta de reconhecimento dos solos do Parque Estadual da Serra do Mar, produzida por ROSSI \& PFEIFER (1991), que a partir de análise da rede de drenagem subdividiram a área em cinco grandes grupos de solos: gley, latossolos, podzólicos, cambissolos e litossolos (ANEXO D).

Este mapa abrangeu uma área de $45.891,0$ ha, compreendida entre as coordenadas UTM 336.000E e 372.0000E, 7.3720.000 N e 7.346.000N, 
tendo como base cartográfica, as folhas do IBGE Santos e Riacho Grande, na escala 1:50.000.

Através de trabalhos de campo identificaram e mapearam oito associações de solo, conforme Tabela 7.

Tabela 7. Classes pedológicas da carta de reconhecimento dos solos do Parque Estadual da Serra do Mar, ROSSI \& PFEIFER (1991).

\begin{tabular}{|c|c|}
\hline Classe & Descrição \\
\hline$L \mathrm{LVa}_{1}$ & $\begin{array}{l}\text { associação de LATOSSOLO VERMELHO-AMARELO A } \\
\text { moderado + LATOSSOLO VERMELHO - AMARELO A } \\
\text { proeminente ambos textura argilosa + CAMBISSOLO ta A } \\
\text { moderado textura média todos ÁLICOS fase floresta tropical } \\
\text { perenifólia relevo montanhoso }\end{array}$ \\
\hline $\mathrm{LVa}_{2}$ & $\begin{array}{l}\text { associação de LATOSSOLO VERMELHO-AMARELO } \\
\text { EPIDISTRÓFICO + LATOSSOLO VERMELHO-AMARELO + } \\
\text { CAMBISSOLO tb + SOLOS LITÓLICOS ta, tb todos ÁLICOS } \\
\text { A moderado textura média fase floresta tropical perenifólia } \\
\text { relevo montanhoso }\end{array}$ \\
\hline $\mathrm{LVa}_{3}$ & $\begin{array}{l}\text { associação de LATOSSOLO VERMELHO-AMARELO } \\
\text { textura argilosa }+ \text { CAMBISSOLO }+ \text { PODZÓLICO } \\
\text { VERMELHO-AMARELO os dois últimos to textura média } \\
\text { todos ÁLICOS A moderado fase floresta tropical perenifólia } \\
\text { relevo montanhoso }\end{array}$ \\
\hline $\mathrm{Ca}_{1}$ & $\begin{array}{l}\text { asSociação de CAMBISSOLO tb + LATOSSOLO } \\
\text { VERMELHO-AMARELO + SOLOS LITÓLICOS ta, tb todos } \\
\text { ÁLICOS A moderado textura média fase floresta tropical } \\
\text { perenifólia relevo montanhoso }\end{array}$ \\
\hline
\end{tabular}


Tabela 7. Classes pedológicas da carta de reconhecimento dos solos do Parque Estadual da Serra do Mar, ROSSI \& PFEIFER (1991).

\begin{tabular}{|l|l|}
\hline Classe & Descrição \\
\hline $\mathrm{Ca}_{2}:$ & $\begin{array}{l}\text { associação de CAMBISSOLO tb relevo ondulado e suave } \\
\text { ondulado + LATOSSOLO VERMELHO-AMARELO relevo } \\
\text { ondulado ambos ÁLICOS A moderado textura média fase } \\
\text { floresta tropical perenifólia }\end{array}$ \\
\hline $\mathrm{Ca}_{3}$ & $\begin{array}{l}\text { associação de CAMBISSOLO + SOLOS LITÓLICOS ambos } \\
\text { ÁLICOS ta, to A moderado textura média fase floresta } \\
\text { tropical perenifólia relevo montanhoso + AFLORAMENTO } \\
\text { DE ROCHA }\end{array}$ \\
\hline A & $\begin{array}{l}\text { associação de SOLOS ALUVIAIS fase floresta tropical } \\
\text { higrófila de várzea + GLEY HÚMICO + GLEY POUCO } \\
\text { HÚMICO + SOLOS ORGÂNICOS os três fase floresta } \\
\text { tropical hidrófila de várzea todos relevo plano }\end{array}$ \\
\hline SM & \begin{tabular}{l} 
solos indiscriminados de mangue \\
\hline OUTROS_S
\end{tabular} áreas urbano-industriais \\
\hline
\end{tabular}

De forma geral, GUERRA \& BOTELHO (1998) descreveram os principais grupos de solos encontrados na área de estudo:

- Gleyssolos são encontrados em planícies aluviais, várzeas e áreas deprimidas por todo o país. São solos hidromórficos, mal drenados, pouco profundos. A textura é, geralmente, argilosa, podendo ser de siltosa a média. Classificam em Glei Húmico, quando possuem horizonte $A$ espesso $(>=20 \mathrm{~cm}$ ), escuro e com teor de matéria orgânica relativamente elevado, caracterizando um A turfoso. Por situarem-se em áreas planas, que não favorecem o escoamento, não apresentam suscetibilidade a erosão relevante. 
- Latossolos são encontrados em áreas de florestas (densa, aberta e mista com palmeiras) e de campo cerrado, em relevo que varia de plano a forte ondulado. Apresentam horizonte $B$ latossólico (Bw), caracterizado por avançado estágio de intemperização; formação de argila de baixa atividade; capacidade de troca cationnica baixa; cores vivas (brunadas, amareladas e avermelhadas); boa agregação; estrutura comumente granular; com pouca ou nenhuma acumulação de argila iluvial. São solos profundos, ácidos e fortemente ácidos, bastante porosos e permeáveis, de textura que varia de média a muito argilosa. De um modo geral apresentam reduzida suscetibilidade à erosão. A boa permeabilidade e drenabilidade e a baixa relação textural B/A (pouca diferenciação no teor de argila do horizonte $A$ para o B) garantem, na maioria dos casos, uma boa resistência desses solos à erosão.

- Podzólicos ocorrem de forma abrangente, sendo que o Podzólico Vermelho-Amarelo é o mais comum no país. São solos com horizonte $B$ textural caracterizado por acumulação de argila. Possuem um horizonte A mais arenoso e um horizonte subsuperficial mais argiloso, o que pode dificultar a infiltração da água, favorecendo o escoamento superficial e subsuperficial na zona de contato dos diferentes materiais. Apresentam certa suscetibilidade a processos erosivos, que serão tão intensos quanto maiores forem as descontinuidades texturais e estruturais ao longo do perfil.

- Cambissolos distribuem-se em ambientes diversos, por praticamente todo o território nacional, sendo importantes na porção oriental dos planaltos dos estado sulistas, Serra do Mar (do Rio Grande do Sul até - Espírito Santo), Serra da Mantiqueira, interior de Minas Gerais, Região Nordeste e na região Amazônica. Apresentam, na sua maioria, teor de argila relativamente baixo (exceção feita àqueles derivados de 
depósitos aluvionares), drenagem variando de acentuada a imperfeita, podendo ser eutróficos ou distróficos. Seu grau de suscetibilidade à erosão varia com a profundidade, sendo os mais rasos mais suscetíveis devido à presença de camada impermeável, representada pelo substrato rochoso mais próximo da superfície, também varia com a declividade do terreno, do teor de silte e do gradiente textural.

- Litossolos ocorrem, geralmente em áreas de topografia acidentada, associados a afloramentos de rocha, distribuídos por todo o país. São pouco evoluídos, rasos, com no máximo $50 \mathrm{~cm}$ até o contato com o substrato rochoso. Por serem pouco espessos, saturam rapidamente, facilitando o escoamento em superfície em subsuperfície. Tal fato pode promover processos erosivos, mais especificamente escorregamentos, se agravando em encostas mais íngremes sem cobertura vegetal.

- Solos Aluviais são encontrados nas margens dos rios e lagos, várzeas, terraços e deltas, tendo uma distribuição não regionalizada. São solos pouco evoluídos, formados a partir de depósitos aluviais, de cor amarelada ou acizentada, moderadamente e bem drenados, de textura silto-argilosa ou média. De um modo geral não apresentam grande risco à erosão devido à ocorrência e topografia plana.

\subsubsection{Mapa da cobertura vegetal}

Utilizou-se o mapa de cobertura vegetal do Parque Estadual da Serra do Mar, produzido por MATTOS \& MATSUKUMA (1990) (ANEXO E) a partir de levantamento aerofotogramétrico de 1985, na escala 1:25.000, em infravermelho falsa cor. Neste, as unidades de vegetação foram classificadas e 
confirmadas com trabalhos de campo observando seu porte, densidade, estrutura e aspectos do seu grau de conservação ou preservação.

Neste mapa foi abrangida uma área de 12.435,98 ha, compreendida entre as coordenadas UTM 346.000E e 368.0000E, 7.370.000N e 7.352.000N, e foram representadas as classes de vegetação descritas na Tabela 8.

Tabela 8. Classes de vegetação do mapa de cobertura vegetal do Parque Estadual da Serra do Mar, MATTOS \& MATSUKUMA (1990).

\begin{tabular}{|l|l|}
\hline Classe & $\begin{array}{l}\text { Descrição } \\
\text { vegetação de tipo arbóreo alto, com pouca alteração em sua } \\
\text { estrutura e composição }\end{array}$ \\
\hline Am & $\begin{array}{l}\text { vegetação de tipo arbóreo médio, com alteração em sua } \\
\text { estrutura e composição }\end{array}$ \\
\hline Ab & $\begin{array}{l}\text { vegetação de tipo arbóreo baixo, com forte alteração em sua } \\
\text { estrutura e composição }\end{array}$ \\
\hline A/A & $\begin{array}{l}\text { vegetação de tipo arbóreo a arbustivo, podendo ser de origem } \\
\text { natural ou não }\end{array}$ \\
\hline H & $\begin{array}{l}\text { vegetação de tipo herbáceo a arbustivo, podendo ser de } \\
\text { origem natural ou não }\end{array}$ \\
\hline Mg & $\begin{array}{l}\text { vegetação de mangue bastante alterada em diversos locais } \\
\text { não evidenciados aqui }\end{array}$ \\
\hline E & reflorestamento - Eucalyptus spp \\
\hline SN & solo nu \\
\hline OUTROS_V & áreas urbano-industriais ou sem informação. \\
\hline
\end{tabular}




\subsubsection{Mapa morfológico}

O mapa morfológico utilizado, foi aquele elaborado por CETESB (1991), através de aerofotointerpretação, contendo os elementos básicos para orientação e definição das categorias dos meios geodinâmicos, na escala 1:50.000 (ANEXO F). Este mapa abrangeu uma área de 13.484,05 ha, compreendida entre as coordenadas UTM 346.000E e 374.0000E, 7.374.000N e 7.352.000N.

Nesse mapa distinguiram-se duas unidades geomorfológicas (ALMEIDA, 1971), conforme Tabela 9.

Tabela 9. Unidades geomorfológicas, CETESB (1991).

\begin{tabular}{|c|c|c|}
\hline $\begin{array}{l}\text { Unidade } \\
\text { Geomorfológica }\end{array}$ & Modelado & $\begin{array}{l}\text { Processo } \\
\text { Morfogenético }\end{array}$ \\
\hline Serrania Costeira & $\begin{array}{l}\text { VCX vertente convexa } \\
\text { VR vertentes retilíneas } \\
\text { VCC vertentes côncavas }\end{array}$ & $\begin{array}{l}\text { escoamento pluvial pre- } \\
\text { ferencialmente concen- } \\
\text { trado, escorregamentos }\end{array}$ \\
\hline \multirow[t]{4}{*}{ Planície Litorânea } & PF planicie fluvial & $\begin{array}{l}\text { inundações, erosão das } \\
\text { margens, depósitos so- } \\
\text { bre o leito maior e nos } \\
\text { segmentos convexos do } \\
\text { leito fluvial }\end{array}$ \\
\hline & RC rampas de colúvio & \\
\hline & $\begin{array}{l}\text { AT área alterada por } \\
\text { ação mecânica }\end{array}$ & \\
\hline & OUTROS_M & áreas urbano-industriais \\
\hline
\end{tabular}




\subsubsection{Mapa litológico}

Este mapa foi adaptado a partir do "Mapa Geológico Compilado Folha de Santos" do IPT (1987), e publicado em relatório técnico da CETESB (1991), na escala 1:50.000 (ANEXO G), abrangendo uma área de $16.737,34$ ha, compreendida entre as coordenadas UTM 346.000E e 374.0000E, $7.374 .000 \mathrm{~N}$ e $7.352 .000 \mathrm{~N}$.

Duas unidades litoestratigráficas foram encontradas na área de estudo:

- Grupo Açungui, constituído pelos complexos Embu e Pilar, do Proterozóico (bloco Juquitiba), e

- Complexo Costeiro (bloco costeiro), delimitados pela zona de falhamento transcorrente de Cubatão, de direção NE - SO.

As classes litológicas contidas nesse mapa são as descritas na

Tabela 10.

Tabela 10. Classes litológicas, CETESB (1991).

\begin{tabular}{|l|l|}
\hline Classe & Descrição \\
\hline Qc & $\begin{array}{l}\text { sedimentos de granulometria muito variada, em depósitos } \\
\text { coluviais no sopé da escarpa, ou em depósitos fluviais na } \\
\text { planície costeira }\end{array}$ \\
\hline $\mathbf{Q p}$ & $\begin{array}{l}\text { areias e argilas ricas em fragmentos vegetais, de } \\
\text { deposição em mangues e pântanos atuais }\end{array}$ \\
\hline $\mathbf{Q b}$ & $\begin{array}{l}\text { areias e argilas ricas em fragmentos vegetais, de } \\
\text { deposição flúvio-lagunar e de baías }\end{array}$ \\
\hline PSEOM & $\begin{array}{l}\text { faixa cataclástica em parte recristalizadas e com } \\
\text { oftalmogênese superposta, brechas tectônicas, flasei- } \\
\text { gnisses, milonitos e filonitos associados a falhamentos de } \\
\text { natureza transcorrente e ou inversa }\end{array}$ \\
\hline
\end{tabular}


Tabela 10. Classes litológicas, CETESB (1991).

\begin{tabular}{|l|l|}
\hline Classe & Descrição \\
\hline PSEOYt & $\begin{array}{l}\text { granito com granulação média fanetítica, aspecto maciço } \\
\text { - Taiaçupeba }\end{array}$ \\
\hline PSEOYm & $\begin{array}{l}\text { granito com granulação média fanetítica, aspecto maciço } \\
\text { - Serra do Morrão }\end{array}$ \\
\hline PSpF & $\begin{array}{l}\text { filitos, sericita-quartzo xistos e clorita xistos com lentes de } \\
\text { quartzitos e mármores }\end{array}$ \\
\hline PSpX & $\begin{array}{l}\text { micaxistos com teores variáveis de quartzo com seixos } \\
\text { achatados. Ocorrem megacristais de microlíneo e } \\
\text { plagioclásio }\end{array}$ \\
\hline PSpQ & quartzitos puros, quartzitos micáceos, itacolomitos \\
\hline PseMc & $\begin{array}{l}\text { migmatitos estromatíticos com paleossoma dominante de } \\
\text { biotita-moscovita-clorita xisto com ou sem sillmanita e } \\
\text { granada }\end{array}$ \\
\hline AcMn & $\begin{array}{l}\text { migmatitos estromatíticos e ou oftalmíticos de neossoma } \\
\text { dominante, e ou nebulíticos. Passam a granitóides } \\
\text { sintectônicos }\end{array}$ \\
\hline AcMp & $\begin{array}{l}\text { oftalmitos com megacristais de andesina, por vezes } \\
\text { estromatíticos }\end{array}$ \\
\hline OSpC & $\begin{array}{l}\text { oftalmitos anatexíticos - Complexo Costeiro cálcio - Silicatados - Complexo Pilar } \\
\text { áreas urbano-industriais }\end{array}$ \\
\hline OC_L
\end{tabular}


As litologias predominantes são:

Bloco Juquitiba:

- Migmatitos homogêneos (AcMn), ocorrendo em faixas alongadas contínuas de direção ENE, nas porções mais altas das escarpas do Vale do Mogi, com granulação média, cor cinza claro ou escuro.

- Migmatitos Estromatíticos (PS e Mc), com paleossoma xistoso dominante com coloração esverdeada e esbranquiçada nas seqüências cioríticas e moscoríticas. Os paleossomas são de quartzo, biotita e muscovita e os neossomas apresentam granulação variada, pegmatóide e fina, formando faixa de bolsões com espessura de milimetros a metros.

- Ectinitos (PSpF, PSpx, PSpQ) constituídos por uma seqüência basal de quartzitos e quartzitos impuros levemente conglomeráticos (PSpQ), com inclusão de lentes anfibolíticas. Os quartzitos estão sobrepostos por granada-biotita-quartzo xistos ou granada-biotita xistos (PSpX) e têm coloração preta brilhante, sendo cinza esverdeada quando alteradas.

\section{Complexo Costeiro:}

- Migmatitos oftalmíticos de Neossoma dominantemente alcali-cálcio (AcMB). presentes na Serra do Morrão e Quilombo e constituídas por oftalmito com megacristais de microlíneo e plágioclásio.

- Migmatitos Estromatíticos de Neossoma Dominante Alcali-Cálcico (AcMB) presentes na Serra do Morrão e Quilombo e constituídos por oftalmito com megacristais de microlíneo e plágioclássio. 
- Suítes graníticas (PSEOy) são corpos graníticos de granulação média, textura fanerítica, coloração rósea e aspecto maciço, constituídos essencialmente por quartzo, plágioclássio microlíneo e, secundariamente, por biotita e moscovita.

- Rochas catacláticas e miloníticas (PSEOM) constituídas por cataclasitos e ultramilonitos.

\subsubsection{Modelos digitais de precipitação}

Esses modelos foram produzidos a partir dos mapas das isoietas de precipitação produzidos por IPT (1985), com dados de 27 postos pluviométricos representativos da área de estudo, na escala 1:100.000, com base no período de 1953 a 1983. Constam de um mapa de isoietas da precipitação média do trimestre mais chuvosos (janeiro, fevereiro e março) (ANEXO H) e outro de isoietas da precipitação média total anual (ANEXO I).

Esses mapas mostraram que as zonas mais chuvosas estão localizadas na borda da escarpa da Serra do Mar, e as zonas menos chuvosas estão localizadas nas bases das encostas. A precipitação média total anual nesse período foi de $2.626 \mathrm{~mm}$, e a precipitação média do trimestre mais chuvoso foi de $944 \mathrm{~mm}$. Abrangeram, cada um, uma área de 80.000 ha, compreendida entre as coordenadas UTM 336.000E e 368.0000E, $7.370 .000 \mathrm{~N}$ e 7.346.000N. 


\subsubsection{Mapa das áreas com escorregamento}

O mapa das áreas com escorregamentos foi aquele elaborado por CETESB (1987), através de fotointerpretação de fotografias aéreas de 1985 , contendo 486 cicatrizes de escorregamentos, na escala 1:50.000 (ANEXO J).

A maior ocorrência de escorregamentos se deu no vale do rio Mogi, concentrando-se mais na vertente de sua margem direita.

As áreas com escorregamento contidos nesse mapa foram utilizados para amostragem dos fatores de instabilidade em áreas com escorregamento.

\subsubsection{Mapa das áreas sem escorregamento}

A partir do mapa das áreas com escorregamento foi gerado mapa das áreas sem escorregamento. Os polígonos que representam os primeiros foram realocados sobre a área de estudo, sendo posicionados em locais onde não houveram escorregamentos no ano de 1985, compondo esse mapa (ANEXO K). Dessa forma, essa áreas foram utilizadas para amostragem dos fatores de instabilidade em áreas sem escorregamento.

Para efeito de amostragem, obtivemos então, amostras iguais de ambas situações que compuseram os dois grupos comparados na análise discriminante. 


\subsection{Atributos associados aos mapas temáticos}

Como foi visto na construção da topologia, atributos foram associados às feições mapeadas. Esses atributos são números que identificaram o tipo de classe, de um determinado mapa temático, que ocorre em determinada unidade de terreno sobre a área de estudo.

Para as classes pedológicas, os atributos utilizados são mostrados na Tabela 11.

Tabela 11. Atributos das classes pedológicas.

\begin{tabular}{|l|l|}
\hline Classe & Atributo \\
\hline $\mathrm{LVa}_{1}$ & 1.000 \\
\hline $\mathrm{LVa}_{2}$ & 2.000 \\
\hline $\mathrm{LVa}_{3}$ & 3.000 \\
\hline $\mathrm{Ca}_{1}$ & 4.000 \\
\hline $\mathrm{Ca}_{2}$ & 5.000 \\
\hline $\mathrm{Ca}_{3}$ & 6.000 \\
\hline$A$ & 7.000 \\
\hline SM & 8.000 \\
\hline OUTROS_S & 9.000 \\
\hline
\end{tabular}

Para as classes de cobertura vegetal, os atributos utilizados são mostrados na Tabela 12. 
Tabela 12. Atributos das classes de cobertura vegetal.

\begin{tabular}{|l|l|}
\hline Classe & Atributo \\
\hline $\mathrm{Aa}$ & 1.000 \\
\hline $\mathrm{Am}$ & 2.000 \\
\hline $\mathrm{Ab}$ & 3.000 \\
\hline $\mathrm{A} / \mathrm{A}$ & 4.000 \\
\hline $\mathrm{H}$ & 5.000 \\
\hline $\mathrm{Mg}$ & 6.000 \\
\hline $\mathrm{E}$ & 7.000 \\
\hline $\mathrm{SN}$ & 8.000 \\
\hline OUTROS_V & 9.000 \\
\hline
\end{tabular}

Para as classes morfológicas, os atributos utilizados são mostrados na Tabela 13.

Tabela 13. Atributos das classes morfológicas.

\begin{tabular}{|l|l|}
\hline Classe & Atributo \\
\hline VCX & 1.000 \\
\hline VR & 2.000 \\
\hline VCC & 3.000 \\
\hline PF & 4.000 \\
\hline RC & 5.000 \\
\hline AT & 6.000 \\
\hline OUTROS_M & 7.000 \\
\hline
\end{tabular}

Para as classes de litológicas, os atributos utilizados são mostrados na Tabela 14. 
Tabela 14. Atributos das classes litológicas.

\begin{tabular}{|l|l|}
\hline Classe & Atributo \\
\hline Qc & 1.000 \\
\hline Qp & 2.000 \\
\hline Qb & 3.000 \\
\hline PSEOM & 4.000 \\
\hline PSEOYt & 5.000 \\
\hline PSEOYm & 6.000 \\
\hline PSpF & 7.000 \\
\hline PSpX & 8.000 \\
\hline PSpQ & 9.000 \\
\hline PseMc & 10.000 \\
\hline AcMn & 11.000 \\
\hline AcMp & 12.000 \\
\hline AcMg & 13.000 \\
\hline PSpC & 14.000 \\
\hline OUTROS_L & 15.000 \\
\hline
\end{tabular}

As áreas com escorregamento, foram identificadas individualmente com os atributos conforme é mostrado na Tabela 15.

Tabela 15. Atributos das área com escorregamento.

\begin{tabular}{|l|l|}
\hline Classe & Atributo \\
\hline áreas com escorregamento & 1 a 486 \\
\hline
\end{tabular}

As áreas sem escorregamento, foram identificadas individualmente com os atributos conforme é mostrado na Tabela 16. 
Tabela 16. Atributos das áreas sem escorregamento.

\begin{tabular}{|l|l|}
\hline Classe & Atributo \\
\hline áreas sem escorregamento & 1 a 486 \\
\hline
\end{tabular}

\subsection{Modelo multivariado de análise discriminante para avaliação do risco de escorregamento}

O modelo multivariado utilizado para a avaliação do risco de escorregamento foi a análise discriminante.

Análise discriminante tem sido usada para avaliações de risco em diversas áreas da ciência. Na área médica SMITH et al. (1991) utilizou esse método para determinar o risco de morte de pacientes cardíacos após cirurgias nas artérias coronárias. $\mathrm{Na}$ área de geoprocessamento e sensoriamento remoto FRANKLIN et al. (1995) usou análise discriminante para detecção de árvores infestadas por Adelges piceae, a partir de imagens multi-espectrais e CARRARA et al. (1991) a usou para a avaliação de risco de escorregamento em uma bacia, na Itália central.

Este modelo requereu que fossem observadas as seguintes etapas:

- definição da área de estudo;

- mapeamento dos escorregamentos na área de estudo;

- levantamento dos fatores envolvidos na ocorrência dos escorregamentos direta ou indiretamente;

- avaliação da contribuição desses fatores na ocorrência de escorregamentos, $e$

- classificação da superfície da terra em classes de risco de escorregamento. 
Análise discriminante é uma técnica analítica adequada, para problemas que envolvem variáveis dependentes categóricas, e muitas variáveis independentes métricas. Em muitos casos, a variável dependente consiste em dois grupos ou classificações, em outros casos, mais do que dois grupos estão envolvidos. Quando duas classificações estão envolvidas, a técnica é referida como análise discriminante de dois grupos, e quando três ou mais classificações são identificadas, a técnica é referida como análise discriminante múltipla. Envolve a combinação linear variáveis independentes que são melhor discriminadas entre os grupos a princípio definidos. A discriminação é obtida aplicando-se pesos para cada variável para maximizar a variância entre grupos em relação à variância dentro do grupo. A combinação linear da análise discriminante, também conhecida como função discriminante, é derivada de uma equação que tem a seguinte forma:

$Z_{j k}=a+W_{1} X_{1 k}+W_{2} X_{2 k}+\ldots+W_{n} X_{n k}$

onde:

$Z_{\mathrm{jk}}=$ valor $Z$ discriminante da função $j$ para o objeto $k$;

$a=$ intercepto;

$W_{i}=$ peso discriminante para a variável independente $i, \mathrm{e}$ $X_{i k}=$ variável independente $i$ para o objeto $k$.

A hipótese testada é a de que as médias de grupos de uma conjunto de variáveis independentes para dois ou mais grupos são iguais. Para tanto, cada variável independente é multiplicada por um peso correspondente e esses produtos são somados juntos. O resultado é uma simples composição do valor $Z$ discriminante para cada indivíduo na análise. Para um grupo em particular é calculado o valor $Z$ discriminante médio. Esta média do grupo é 
referida como centróide. Quando a análise envolve dois grupos, há dois centróides; com três grupos, três centróides, e assim por diante. Os centróides indicam a localização mais comum para qualquer indivíduo de um grupo em particular, e a comparação de centróides de grupos mostra o quão próximos estão os grupos ao longo da dimensão que está sendo testada.

O teste de significância estatística da função discriminante é a medida generalizada da distância entre os centróides dos grupos. Isto é computado comparando-se as distribuições dos valores discriminantes. Se a sobreposição dos grupos é pequena, a função discriminante separa bem os grupos. Se a sobreposição é grande, a função discriminante separa mal os grupos.

Uma característica marcante da análise discriminante múltipla é quanto às relações de dependência de interesse: se há mais de dois grupos na variável dependente, a análise discriminante calculará mais que uma função discriminante, ou seja NG-1 funções, onde NG é o número de grupos. Cada função discriminante calculará um valor de $Z$ discriminante.

A aplicação e interpretação da análise discriminante é muito parecida com a análise de regressão, isto é, a função discriminante é uma combinação linear de medições métricas para duas ou mais variáveis independentes e é usada para descrever ou predizer uma variável dependente simples. A chave da diferença entre elas é que a análise discriminante é apropriada para problemas de pesquisa onde a variável dependente é categórica, enquanto a análise de regressão é utilizada quando a variável dependente é métrica.

Os objetivos da análise discriminante são:

- determinar se diferenças estatisticamente significantes existem entre valores médios de um conjunto de variáveis para dois, ou mais, grupos definidos previamente; 
- determinar quais das variáveis independentes contam mais para as diferenças entre os valores médios de dois ou mais grupos;

- estabelecer procedimentos para classificar objetos em grupos com base em seus valores de um grupo de variáveis independentes, e

- estabelecer o número e composição das dimensões de discriminação entre grupos formados a partir de um conjunto de variáveis independentes.

Análise discriminante pode ser vista como um tipo de análise de perfil ou uma técnica analítica preditiva.

O sucesso da aplicação da análise discriminante requer várias considerações, que incluem a seleção de ambas as variáveis dependente e independente, o tamanho da amostra necessária para estimação das funções discriminantes e a divisão da amostra para propósitos de avaliação.

Os grupos de variáveis dependentes podem ser dois ou mais, mas estes grupos devem ser mutuamente exclusivos e exaustivos. Isso significa que cada observação deve estar localizada em um único grupo.

Análise discriminante é muito sensível para a taxa entre o tamanho da amostra e o número de variáveis de predição. Muitos estudos sugerem uma taxa de 20 observações para cada variável de predição. $\mathrm{O}$ tamanho mínimo recomendado é de 5 observações para cada variável independente.

A análise discriminante foi processada no software estatístico SAS, utilizando o procedimento DISCRIM. Dentro desse procedimento, quando a distribuição dentro de cada grupo é assumida como normal multivariada, um método paramétrico pode ser usado para desenvolver a função discriminante. A função discriminante, também conhecida como critério de classificação, é determinada pela medida generalizada do quadrado da distância. O critério de classificação pode ser baseado em uma matriz de covariância intragrupo individual ou em uma matriz de covariância agrupada, levando em conta as probabilidades prévias dos grupos. A informação de calibração pode ser 
armazenada em um conjunto de dados especial SAS e aplicado em outros conjuntos de dados. O procedimento DISCRIM avalia a performance da função discriminante através da estimativa das taxas de erro (probabilidade de desclassificação) na classificação de futuras observações. Esta taxa de erro estimada incluí a contagem de erros estimado e probabilidade posterior da taxa de erro estimado. As probabilidades prévias são estimadas pelo Teorema de Bayes, o qual assume que as probabilidade prévias de um membro de um grupo ser conhecido e a densidade de grupo específica para $\mathbf{x}$ podem ser estimadas, e calcula $p(t \mid \mathbf{x})$, a probabilidade de $\mathbf{x}$ pertencer ao grupo $t$, por

$p(t \mid x)=q_{t} f_{t}(\mathbf{x}) / f(x)$

No presente caso, o método normal foi especificado para derivar a função discriminante linear, o que significa que se assumiu uma distribuição normal multivariada intra-classe, e foi usada uma matriz de covariância agrupada no cálculo do quadrado da distância generalizada, gerando uma função discriminante linear.

\subsubsection{Métodos paramétricos}

Assumindo que cada grupo teve um distribuição normal multivariada, o procedimento DISCRIM desenvolveu uma função discriminante usando uma medida da distância ao quadrado generalizada. O critério de classificação foi baseado na matriz de covariância intragrupo ou na matriz de covariância agrupada. Cada observação foi colocada na classe na qual ela teve o menor quadrado da distância generalizada. O procedimento DISCRIM 
também calculou a probabilidade posterior de uma observação pertencer a cada classe. $O$ quadrado da distância de $\mathrm{x}$ para um grupo $t$ foi dado por:

$d^{2}(x)=\left(x-m_{t}\right)^{\prime} V_{t}-1\left(x-m_{t}\right)$

onde: $\mathbf{V}_{\mathrm{t}}=\mathbf{S}_{\mathrm{t}}$ se a matriz de covariância intra-grupo é usada ou $\mathbf{V}_{\mathrm{t}}=\mathbf{S}$ se a matriz de covariância agrupada é usada.

A densidade específica de grupo estimada para $\mathbf{x}$ de um grupo $t$ foi dada por:

$f_{t}(\mathbf{x})=(2 \pi)^{-p / 2}\left|\mathbf{V}_{\mathrm{t}}\right|^{-1 / 2} \exp \left(-0,5 d^{2}{ }_{t}(\mathbf{x})\right)$

Usando o teorema de Bayes, a probabilidade posterior de $\mathbf{x}$ pertencer ao grupo $t$ foi dada por:

$p(t \mid x))=q_{t} f_{t}(x) / \Sigma_{u} q_{u} f_{u}(x)$

onde a somatória foi sobre todos os grupos.

$\mathrm{O}$ quadrado da distância generalizada de $\mathrm{x}$ para um grupo $\mathrm{t}$ foi definido como:

$D^{2}(x)=d^{2}(x)+g_{1}(t)+g_{2}(t)$

onde:

$g_{1}(t)=\log ^{e}\left|\mathbf{S}_{t}\right| \quad$ se a matriz de covariância intra-grupo é usada;

$g_{1}(t)=0 \quad$ se a matriz de covariância agrupada é usada;

$g_{2}(t)=-2 \log ^{e}\left|q_{t}\right| \quad$ se as probabilidades prévias não são iguais, $e$ 
$g_{2}(t)=0 \quad$ se as probabilidades prévias são iguais.

A probabilidade posterior de $\mathbf{x}$ pertencer ao grupo $t$ foi:

$p(t \mid x)=\exp \left(-0,5 D_{t}^{2}(\mathbf{x})\right) / \Sigma_{u} \exp \left(-0,5 D^{2}(\mathbf{x})\right)$

Uma observação foi classificada dentro de um grupo $u$ se $t=u$ produziu o maior valor de $p(t \mid x)$ ou o menor valor de $D_{t}^{2}(\mathbf{x})$. Se esta probabilidade posterior foi menor que o limiar especificado, $\mathbf{x}$ foi classificado dentro de outro grupo.

\subsubsection{Descrição das variáveis}

A variável categórica dependente estudada foi definida em dois grupos, um de áreas com escorregamento e outro de áreas sem escorregamento.

As variáveis independentes, consideradas fatores de instabilidade, foram: a hipsometria, a clinografia, a exposição de vertentes, as classes pedológicas, as classes de cobertura vegetal, as classes morfológicas, as classes litológicas, as alturas de precipitação média do trimestre mais chuvoso e da precipitação média total anual.

Essas variáveis foram quantificadas nos dois grupos considerados. 


\subsubsection{Geração de tabelas para análise discriminante}

Para cada área com escorregamento e sem escorregamento, foi feito um levantamento da ocorrência de cada fator de instabilidade. Dentro da área de estudo haviam 433 áreas com escorregamento e 432 áreas sem escorregamento. De cada grupo foram selecionadas 108 áreas como amostra de validação do modelo, restando 325 áreas com escorregamento e 324 áreas sem escorregamento como amostra de análise, com a qual foi construída a tabela de dados para aplicação da análise discriminante.

Esse levantamento foi feito utilizando-se duas ferramentas de geoprocessamento existentes no ArcView Spatial Analyst.

Uma, foi a que permitiu operações algébricas com os arquivos matriciais, com a qual foi efetuada a soma dos arquivos matriciais de áreas com escorregamentos e áreas sem escorregamentos com os arquivos matriciais de pedologia, cobertura vegetal, morfologia e litologia, gerando tabelas de resultados para cada combinação. Obteve-se então, para cada área de escorregamento e sem escorregamento, a porcentagem de ocorrência de cada variável em seu interior. Dessa forma, as combinações feitas, foram:

- área com escorregamento + pedologia

- área com escorregamento + cobertura vegetal

- área com escorregamento + morfologia

- área com escorregamento + litologia

- área sem escorregamento + pedologia

- área sem escorregamento + cobertura vegetal

- área sem escorregamento + morfologia

- área sem escorregamento + litologia 
Sendo os atributos dos mapas temáticos de pedologia, cobertura vegetal, morfologia e litologia, todos múltiplos de 1.000 , enquanto os atributos das áreas com e sem escorregamentos variaram de 1 a 486, o resultado da soma de uma célula de um mapa temático com uma célula de área, com ou sem escorregamento, só pôde ser obtido a partir de uma única combinação. Para ilustrar essa operação, considere no mapa de pedologia a classe pedológica $L V a_{1}$, que tem atributo 1.000 , e a classe pedológica $C a_{1}$, que tem atributo 4.000. Considerando uma área com escorregamento, por exemplo, com atributo 200, composta de quatro células, temos que:

(pedologia)

\begin{tabular}{|l|l|}
\hline 1.000 & 1.000 \\
\hline 4.000 & 1.000 \\
\hline
\end{tabular}

(escorregamento)

\begin{tabular}{|l|l|}
\hline 200 & 200 \\
\hline 200 & 200 \\
\hline
\end{tabular}

(resultado)

\begin{tabular}{|l|l|}
\hline 1.200 & 1.200 \\
\hline 4.200 & 1.200 \\
\hline
\end{tabular}

O resultado 1.200 só pôde ser obtido pela combinação do atributo $1.000 \mathrm{com}$ o atributo 200 , e o resultado 4.200 só pôde ser obtido pela combinação do atributo 4.000 com o atributo 200. Logo, quanto a pedologia, a área identificada pelo atributo 200 , é composta por $75 \%$ do solo tipo $\operatorname{LVa}_{1}(1.000)$ e por $25 \%$ do solo tipo $\mathrm{Ca}_{1}(4.000)$.

Outra ferramenta, foi aquela que permitiu que dois mapas fossem sobrepostos, de forma que um deles representasse uma máscara para o outro, extraindo suas informações somente em áreas determinadas. Os mapas de áreas com escorregamento e de áreas sem escorregamento, serviram de máscara para os mapas de hipsometria, clinografia, exposição de vertentes, precipitação média do trimestre mais chuvoso e precipitação média total anual. Obteve-se assim o valor médio dessas variáveis, para cada área com escorregamento e sem escorregamento.

- área com escorregamento $\mathrm{x}$ hipsometria 
- área com escorregamento x clinografia

- área com escorregamento x exposição de vertentes

- área com escorregamento x precipitação média do trimestre mais chuvoso

- área com escorregamento x precipitação média total anual

- área sem escorregamento $\mathrm{x}$ hipsometria

- área sem escorregamento x clinografia

- área sem escorregamento x exposição de vertentes

- área sem escorregamento x precipitação média do trimestre mais chuvoso

- área sem escorregamento x precipitação média total anual

Para ilustrar essa operação, considere no mapa de hipsometria, onde cada célula possui como atributo a altitude do terreno naquele ponto. Considerando uma área com escorregamento, por exemplo, com atributo 200 , composta de quatro células, temos que:

(hipsometria)

\begin{tabular}{|l|l|}
\hline 104 & 104 \\
\hline 105 & 108 \\
\hline
\end{tabular}

(escorregamento)

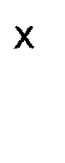

\begin{tabular}{|l|l|}
\hline 200 & 200 \\
\hline 200 & 200 \\
\hline
\end{tabular}

(resultado)

\begin{tabular}{|l|l|}
\hline 105,2 & 105,2 \\
\hline 105,2 & 105,2 \\
\hline
\end{tabular}

O resultado 105,2 é a média aritmética das altitudes das células que compõem a área de escorregamento de atributo 200 .

Os resultados encontrados nas operações descritas anteriormente compuseram a tabela utilizada para a aplicação da análise discriminante sobre a amostra de análise, com 45 variáveis medidas nos dois grupos, conforme é mostrado na Tabela 17. 
Tabela 17. Tabela de dados para aplicação da análise discriminante sobre a amostra de análise.

\begin{tabular}{|c|c|c|c|c|c|c|c|c|c|c|c|c|c|c|c|c|c|c|c|c|c|c|c|c|c|c|c|}
\hline \multirow[b]{2}{*}{ GRUPO } & \multirow{2}{*}{\multicolumn{2}{|c|}{$\begin{array}{c}\text { HIPSO } \\
\text { METRIA } \\
\text { MÉDIA } \\
\text { (m) }\end{array}$}} & \multirow{2}{*}{\multicolumn{2}{|c|}{$\begin{array}{c}\text { CLINO- } \\
\text { GRAFIA } \\
\text { MÉDIA } \\
\left.0^{\circ}\right)\end{array}$}} & \multirow{2}{*}{\multicolumn{2}{|c|}{$\begin{array}{c}\text { EXPOSF } \\
\text { CAOO DE } \\
\text { VERTEN } \\
\text { TE. } \\
\text { MEDIA } \\
\left.0^{\circ}\right)\end{array}$}} & \multirow[b]{2}{*}{\begin{tabular}{|c|} 
PREC \\
MEDIA \\
DO \\
TRMA \\
MAIS \\
CHUV. \\
(mm) \\
\end{tabular}} & \multirow[b]{2}{*}{\begin{tabular}{|c|} 
PREC \\
MEDA \\
TOTAL \\
ANUAL \\
(mm) \\
\end{tabular}} & \multicolumn{10}{|c|}{ PEDOLOGIA } & \multicolumn{9}{|c|}{ COBERTURA VEGETAL } \\
\hline & & & & & & & & & (2) & b) & 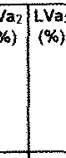 & $\begin{array}{l}\mathrm{Ca} \\
(\%)\end{array}$ & $\begin{array}{l}\mathrm{Ca} \\
\mathrm{Ca}\end{array}$ & $\begin{array}{l}\mathrm{C}_{2} \\
\text { (\%) }\end{array}$ & 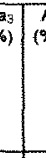 & & (\%) & $\begin{array}{c}\text { Ou } \\
\text { TROS } \\
\text { S } \\
(\%)\end{array}$ & $\begin{array}{l}A \mathrm{Aa} \\
(\%)\end{array}$ & Am & $\begin{array}{l}A b \\
(\%)\end{array}$ & \begin{tabular}{|l|}
$\mathrm{A}$ \\
$(\%)$
\end{tabular} & $\begin{array}{c}A \\
(\%)\end{array}$ & \begin{tabular}{c|}
$\mathrm{Mg}$ \\
$(\%)$ \\
$(\%)$
\end{tabular} & \begin{tabular}{|c|}
$E$ \\
$(\%)$
\end{tabular} & \begin{tabular}{|l} 
SNN \\
$(\%)$
\end{tabular} & $\begin{array}{c}\alpha \\
\text { Tros } \\
v \\
(\%)\end{array}$ \\
\hline $\begin{array}{l}\text { AREACOM } \\
\text { ESCORRE- } \\
\text { GAMENTO }\end{array}$ & & & & & & & & & & & & & & & & & & & & & & & & & & & \\
\hline $\begin{array}{l}\text { AREA SEM } \\
\text { ESCORRE- } \\
\text { GAMENTO }\end{array}$ & & & & & & & & & & & & & & & & & & & & & & & & & & & \\
\hline & & & & ORFO & LOGIP & & & & & & & & & & & & & TOLOGI & & & & & & & & & \\
\hline GRUPO & \begin{tabular}{|l|} 
VCX \\
$(\%)$
\end{tabular} & $\begin{array}{l}\mathrm{VR} \\
(\%)\end{array}$ & \begin{tabular}{|l|l|}
$\mathrm{PCC}$ \\
$(\% \%)$
\end{tabular} & $\begin{array}{l}\text { PF } \\
(\%)\end{array}$ & \begin{tabular}{|l}
$R C$ \\
$(\%)$
\end{tabular} & $\begin{array}{l}\text { AT } \\
(\%)\end{array}$ & \begin{tabular}{|c|} 
out \\
ros \\
$M-$ \\
$M$ \\
$(\%)$
\end{tabular} & $\begin{array}{l}0 c \\
(\%)\end{array}$ & $\begin{array}{l}\mathrm{Op} \\
(\%)\end{array}$ & \begin{tabular}{|l|}
$\mathrm{ab}$ \\
$(\%)$
\end{tabular} & $\begin{array}{c}\text { PSEOM } \\
(\%)\end{array}$ & & $\begin{array}{l}\text { SEOY } \\
\text { (\%) }\end{array}$ & & $\begin{array}{l}\text { SEOY } \\
(\%)\end{array}$ & & $\begin{array}{l}\text { PSpF } \\
(\%)\end{array}$ & $\begin{array}{l}P S p \\
(\%)\end{array}$ & & $\begin{array}{c}\text { PSpQ } \\
(\%)\end{array}$ & \begin{tabular}{|c} 
Psem \\
$(\%)$
\end{tabular} & & $\begin{array}{l}\mathrm{cmm} \\
(\%)\end{array}$ & \begin{tabular}{|l|}
$A c$ \\
$M$ \\
$M(\%)$ \\
$(\%)$
\end{tabular} & \begin{tabular}{|l}
$\mathrm{Ac}$ \\
$\mathrm{Mg}$ \\
$(\%)$
\end{tabular} & $\begin{array}{l}P S \\
p C \\
(\%)\end{array}$ & $\begin{array}{c}\text { out } \\
\text { TROS } \\
\text { L(\%) }\end{array}$ \\
\hline $\begin{array}{l}\text { AREA COM } \\
\text { ESCORRE- } \\
\text { GAMENTO }\end{array}$ & & & & & & & & & & & & & & & & & & & & & & & & & & & \\
\hline $\begin{array}{l}\text { AREA SEM } \\
\text { ESCORRE- } \\
\text { GAMENTO }\end{array}$ & & & & & & & & & & & & & & & & & & & & & & & & & & & \\
\hline
\end{tabular}

\subsubsection{Função discriminante}

Com os dados da amostra de análise, da Tabela 17, foram calculados os coeficientes da função discriminante, e a probabilidade prévia dos elementos da amostra pertencerem a cada um dos grupos. Essa função foi aplicada sobre os próprios elementos da amostra, calculando-se para cada um o valor de $Z$ discriminante, que serviu de base para o cálculo da probabilidade posterior de pertencerem a cada um dos grupos, nos quais foram previamente inseridos. Isso significa que cada elemento da amostra foi reclassificado pela função discriminante, em termos de probabilidade de pertencer a um ou outro grupo. Um resumo dessa reclassificação foi produzido, contendo o número e a taxa de erros e acertos em cada grupo e no geral.

Em seguida, a função discriminante foi aplicada sobre a amostra de validação, para avaliar-se sua eficiência, uma vez que os dados dessa amostra não foram os mesmos que geraram os coeficientes da função. Cada elemento da amostra de validação foi reclassificado pela função discriminante em termos de probabilidade de pertencer a um ou outro grupo e um resumo 
dessa reclassificação foi produzido, contendo o número e a taxa de erros e acertos em cada grupo e no geral.

\subsubsection{Mapa de risco de escorregamento}

Verificada a eficiência da função discriminante em classificar áreas quanto a sua probabilidade de ser um escorregamento ou não, esta foi aplicada em cada unidade de terreno da área de estudo. Os dados foram organizados como é mostrado na Tabela 18, onde cada unidade de terreno foi identificada pelas suas coordenadas $x, y$, UTM $(N, E)$, e teve seus fatores de instabilidade, contemplados na função discriminante, quantificados e listados. Essa tabela foi gerada no ArcView Spatial Analyst, a partir dos arquivos matriciais de cada fator de instabilidade, em forma de arquivo dBASE.

Tabela 18. Fatores de instabilidade para cada unidade de terreno da área de estudo.

\begin{tabular}{|c|c|c|c|c|c|c|c|c|c|c|c|c|c|c|c|c|c|c|c|c|c|c|}
\hline \multicolumn{2}{|c|}{ UTM $(\mathrm{N}, \mathrm{E})$} & & & & & & & \multicolumn{7}{|c|}{ PEDOLOGIA } & \multicolumn{8}{|c|}{ COBERTURA VEGETAL } \\
\hline $\begin{array}{c}x \\
(m)\end{array}$ & $\begin{array}{c}Y \\
(m)\end{array}$ & \begin{tabular}{|l|} 
HIP- \\
SO \\
ME- \\
TRIA \\
(m)
\end{tabular} & $\begin{array}{l}\text { CLINO } \\
\text { GRAFL } \\
(0)\end{array}$ & A & $\begin{array}{l}\text { EXP. } \\
\text { DE } \\
\text { VER- } \\
\text { ENTE } \\
\sigma^{(T)}\end{array}$ & $\begin{array}{l}\text { PREC } \\
\text { MEDIA } \\
\text { DO } \\
\text { TRIM. } \\
\text { MAIS } \\
\text { CHUL } \\
\text { VOSO } \\
\text { (mOn) }\end{array}$ & $\begin{array}{l}\text { PREC. } \\
\text { MÉDIA } \\
\text { TOT. } \\
\text { ANL } \\
\text { AL } \\
\text { (mm) }\end{array}$ & {$\left[\begin{array}{l}\text { lva } \\
\text { (\%) }\end{array}\right.$} & $\mid \begin{array}{c}\mid \mathrm{Va}_{3} \\
(\%)\end{array}$ & \begin{tabular}{l|l}
3 & $C a$ \\
$(\%)$
\end{tabular} & $\begin{array}{l}\mathrm{Ca}_{2} \\
(\%)\end{array}$ & $\begin{array}{l}\mathrm{Ca} \\
(\%)\end{array}$ & $\begin{array}{c}\mathrm{A} \\
(\%)\end{array}$ & $\begin{array}{c}\text { OU } \\
\text { TROS } \\
\text { S } \\
(\%)\end{array}$ & $\begin{array}{c}\mathrm{Aa} \\
(\%)\end{array}$ & $\begin{array}{l}\mathrm{Am} \\
(\%)\end{array}$ & $\begin{array}{l}A_{b} \\
(\%)\end{array}$ & $\begin{array}{l}\text { A/A } \\
(\%)\end{array}$ & $\begin{array}{c}\mathrm{H} \\
(\%)\end{array}$ & \begin{tabular}{|c|}
$E$ \\
$(\%)$
\end{tabular} & \begin{tabular}{|l|}
$\mathbf{S N}$ \\
$(\%)$
\end{tabular} & $\begin{array}{c}\text { OU } \\
\text { TROS } \\
v \\
(\%)\end{array}$ \\
\hline \multicolumn{2}{|c|}{ UTM (N,E) } & \multicolumn{6}{|c|}{ MORFOLOGIA } & \multicolumn{15}{|c|}{ LITOLOGK } \\
\hline $\begin{array}{c}x \\
(m)\end{array}$ & $\begin{array}{c}Y \\
(\mathrm{~m})\end{array}$ & \begin{tabular}{l|} 
VCX \\
$(\%)$
\end{tabular} & \begin{tabular}{|l|}
$\mathrm{VR}$ \\
$(\%)$
\end{tabular} & $\begin{array}{l}\mathrm{RC} \\
(\%)\end{array}$ & $\begin{array}{c}\text { AT } \\
(\%)\end{array}$ & $\begin{array}{r}\text { Oार० } \\
(\%)\end{array}$ & SS, & $\begin{array}{r}\text { PSEO) } \\
(\%)\end{array}$ & & $\begin{array}{l}\text { PSEOY } \\
(\%)\end{array}$ & & $\begin{array}{l}\text { PSpF } \\
(\%)\end{array}$ & $\begin{array}{r}\text { PSp } \\
\text { (\%) }\end{array}$ & \begin{tabular}{c|c}
$\mathrm{PSEM}$ \\
\\
$(\%)$
\end{tabular} & & $\begin{array}{l}\text { AcMn } \\
(\%)\end{array}$ & $\begin{array}{c}\mathrm{AcM} \\
(\%)\end{array}$ & & $\begin{array}{c}\text { PSpC } \\
(\%)\end{array}$ & & OUTR & $\begin{array}{l}205 \mathrm{~L} \\
\%)\end{array}$ \\
\hline
\end{tabular}

Como resultado da aplicação da função discriminante nos dados da Tabela 18, obteve-se outra tabela, também em formato dBASE, onde cada unidade de terreno teve sua probabilidade de pertencer a cada grupo, calculada e associada a suas coordenadas, conforme a Tabela 19. 
Tabela 19. Probabilidade das unidades de terreno serem ou não escorregamentos.

\begin{tabular}{|c|c|c|c|}
\hline$X(m)$ & $Y(m)$ & $\begin{array}{c}\text { Probabilidade pertencer ao grupo } \\
\text { de áreas com escorregamento }\end{array}$ & $\begin{array}{c}\text { Probabilidade de pertencer ao grupo } \\
\text { de áreas sem escorregamento }\end{array}$ \\
\hline
\end{tabular}

Essas probabilidades variam entre 0 (zero) e 1 (um), e são complementares, ou seja, sua soma é igual a 1, para cada unidade de terreno.

A probabilidade de pertencer ao grupo de áreas com escorregamento foi considerada como sendo a probabilidade potencial espacial de cada unidade de terreno ser ou não um escorregamento, ou em outros termos, o risco de ocorrência ou não de escorregamento em cada uma.

Os dados da Tabela 19 foram introduzidos no do SIG, gerando uma mapa, com a grade de células adotada, onde cada célula tinha como atributo sua probabilidade de ser ou não um escorregamento. Considerando somente a probabilidade de serem escorregamentos como atributo, foi feita uma reclassificação do mapa, agrupando-se essas probabilidades em classes de risco de escorregamento, descritas na Tabela 20.

Tabela 20. Classes de risco de escorregamento.

\begin{tabular}{|l|l|}
\hline Probabilidade & Classe \\
\hline 0,0 a 0,2 & muito baixo \\
\hline 0,2 a 0,4 & baixo \\
\hline 0,4 a 0,6 & médio \\
\hline 0,6 a 0,8 & alto \\
\hline 0,8 a 1,0 & muito alto \\
\hline
\end{tabular}

Posteriormente realizou-se o cruzamento das classes de risco de escorregamento com as classes de cada fator de instabilidade para uma caracterização das mesmas, utilizando-se ferramentas de geoprocessamento existentes no ArcView Spatial Analyst. 


\title{
4 RESULTADOS E DISCUSSÃO
}

\begin{abstract}
A superfície da área de estudo é de $107.069 .800,0 \mathrm{~m}^{2}$. Dentro dessa área foram amostradas áreas com escorregamento, num total de $942.362,9 \mathrm{~m}^{2}$, e áreas sem escorregamento, num total de $937.083,5 \mathrm{~m}^{2}$, ou seja, $0,9 \%$ e $0,9 \%$ da área de estudo, respectivamente.

Primeiramente, analisou-se a ocorrência da classes de cada fator de instabilidade na área de estudo, nas áreas com escorregamento e nas áreas sem escorregamentos, com o objetivo de caracterizá-las em função dos mesmos.
\end{abstract}

\subsection{Características da área de estudo}

Para uma caracterização da área de estudo, analisou-se a ocorrência das classes de cada fator de instabilidade na mesma, conforme é mostrado nas Tabelas 21, 22, 23, 24, 25, 26, 27, 28 e 29. 
Tabela 21. Ocorrência das classes hipsométricas na área de estudo.

\begin{tabular}{|l|r|r|}
\hline Classe $(\mathrm{m})$ & \multicolumn{1}{|c|}{ Área $\left(\mathrm{m}^{2}\right)$} & \multicolumn{1}{c|}{$(\%)$} \\
\hline $0-100$ & $39.538 .380,1$ & 36,9 \\
\hline $100-300$ & $26.187 .618,0$ & 24,5 \\
\hline $300-500$ & $18.210 .821,1$ & 17,0 \\
\hline $500-700$ & $14.602 .677,3$ & 13,6 \\
\hline $700-900$ & $8.076 .698,1$ & 7,5 \\
\hline $900-1.100$ & $453.605,5$ & 0,4 \\
\hline total & $107.069 .800,0$ & 100,0 \\
\hline
\end{tabular}

Observa-se, na Tabela 21 , que $61,4 \%$ da área de estudo encontra-se na baixa encosta, entre $0 \mathrm{~m}$ e $300 \mathrm{~m}$ de altitude. A alta encosta, acima de $500 \mathrm{~m}$, onde se encontram as declividades mais acentuadas e têm sido observados escorregamentos com maior freqüência (BACCARO, 1985), compreende $21,5 \%$ da mesma.

Tabela 22. Ocorrência das classes clinográficas na área de estudo.

\begin{tabular}{|l|r|r|}
\hline Classe $\left(^{0}\right)$ & \multicolumn{1}{|c|}{ Área $\left(\mathrm{m}^{2}\right)$} & \multicolumn{1}{c|}{$(\%)$} \\
\hline $0^{\circ}-7^{\circ}$ & $30.343 .868,4$ & 28,3 \\
\hline $7^{\circ}-17^{\circ}$ & $20.792 .052,4$ & 19,4 \\
\hline $17^{\circ}-25^{\circ}$ & $28.455 .645,5$ & 26,6 \\
\hline $25^{\circ}-36^{\circ}$ & $23.798 .088,9$ & 22,2 \\
\hline $36^{\circ}-45^{\circ}$ & $3.574 .843,4$ & 3,3 \\
\hline$>45^{\circ}$ & $105.301,3$ & 0,1 \\
\hline total & $107.069 .800,0$ & 100,0 \\
\hline
\end{tabular}

Como é mostrado na Tabela 22, $52,2 \%$ da área de estudo possui declividades superiores a $17^{\circ}$. Em seus estudos em Caraguatatuba, SP, CRUZ 
(1975) considerou a declividade de $15^{\circ}$ como limite de declividade a partir do qual observou grande freqüência de cicatrizes de movimentos e GOES (1990) atribuiu a declividades superiores a $25^{\circ}$, combinadas a outros fatores, grande peso na identificação de áreas críticas quanto ao movimento de massa. Portanto, quanto a clinografia, a área de estudo apresenta-se propícia a movimentos de massa.

Tabela 23. Ocorrência das classes de exposição de vertentes na área de estudo.

\begin{tabular}{|l|r|r|}
\hline Classe & \multicolumn{1}{|c|}{ Área $\left(\mathrm{m}^{2}\right)$} & \multicolumn{1}{|c|}{$(\%)$} \\
\hline N (norte) & $6.436 .878,2$ & 6,0 \\
\hline NE (nordeste) & $5.154 .362,6$ & 4,8 \\
\hline L (leste) & $13.149 .159,7$ & 12,3 \\
\hline SE (sudeste) & $23.131 .180,8$ & 21,6 \\
\hline S (sul) & $19.302 .534,4$ & 18,0 \\
\hline SO (sudoeste) & $8.783 .206,6$ & 8,2 \\
\hline O (oeste) & $10.176 .423,6$ & 9,5 \\
\hline NO (noroeste) & $12.386 .850,4$ & 11,6 \\
\hline PLANO & $8.549 .203,8$ & 8,0 \\
\hline total & $107.069 .800,0$ & 100,0 \\
\hline
\end{tabular}

$\mathrm{Na}$ Tabela 23, observa-se que na área de estudo predominam vertentes com orientação sudeste (SE) $(21,6 \%)$ e sul (S) $(18,0 \%)$. A direção predominante do vento na região é sudeste (CETESB, 1991) (TROPPMAIR \& FERREIRA 1987), o que faz com que os poluentes gerados pelo pólo industrial de Cubatão sejam carregados e depositados com maior intensidade nessas vertentes. 
Tabela 24. Ocorrência das classes pedológicas na área de estudo.

\begin{tabular}{|l|r|r|}
\hline Classe $\left.{ }^{*}\right)$ & \multicolumn{1}{|c|}{ Área $\left(\mathrm{m}^{2}\right)$} & \multicolumn{1}{c|}{$(\%)$} \\
\hline $\mathrm{LVa}_{1}$ & $35.981 .241,8$ & 33,6 \\
\hline $\mathrm{LVa}_{2}$ & 0,0 & 0,0 \\
\hline $\mathrm{LVa}_{3}$ & $38.678 .619,9$ & 36,1 \\
\hline $\mathrm{Ca}_{1}$ & $1.440 .041,7$ & 1,3 \\
\hline $\mathrm{Ca}_{2}$ & $3.048 .388,3$ & 2,8 \\
\hline $\mathrm{Ca}_{3}$ & $2.826 .981,8$ & 2,6 \\
\hline $\mathrm{A}$ & $11.812 .842,0$ & 11,0 \\
\hline SM & $1.047 .630,3$ & 1,0 \\
\hline OUTRO_S & $12.234 .054,2$ & 11,4 \\
\hline total & $107.069 .800,0$ & 100,0 \\
\hline
\end{tabular}

(*) descrição das classes na Tabela 7.

Os dados da Tabela 24, mostram que predominam duas classes de latossolos vermelho-amarelo na área de estudo, a de $\operatorname{LVa}_{3}(36,1 \%)$ e a de $\mathrm{LVa}_{1}(33,6 \%)$, que em geral são solos bastante porosos e permeáveis, de textura que varia de média a muito argilosa. Embora sejam solos que geralmente apresentam boa resistência a erosão, na área de estudo estão associados a presença de altas declividades e cobertura vegetal alterada, deixando-os mais expostos a fatores erosivos, como a precipitação ou ação antrópica. 
Tabela 25. Ocorrência das classes de cobertura vegetal na área de estudo.

\begin{tabular}{|l|r|r|}
\hline Classe & \multicolumn{1}{|c|}{ Área $\left(\mathrm{m}^{2}\right)$} & \multicolumn{1}{|c|}{ (\%) } \\
\hline Aa (arbóreo alto) & $2.602 .674,9$ & 2,4 \\
\hline Am (arbóreo médio) & $18.713 .903,0$ & 17,5 \\
\hline Ab (arbóreo baixo) & $39.980 .871,1$ & 37,3 \\
\hline A/A (arbóreo à arbustivo) & $9.622 .455,6$ & 9,0 \\
\hline H (herbáceo à arbustivo) & $21.868 .716,1$ & 20,4 \\
\hline Mg (mangue) & $820.398,4$ & 0,8 \\
\hline E (reflorestamento) & $767.113,8$ & 0,7 \\
\hline SN (solo nu) & $866.333,4$ & 0,8 \\
\hline OUTROS_V & $11.827 .333,7$ & 11,0 \\
\hline total & $107.069 .800,0$ & 100,0 \\
\hline
\end{tabular}

$\mathrm{Na}$ Tabela 25 fica evidenciado 0 nível de degradação da cobertura vegetal na área de estudo, observando-se a predominância de vegetação de tipo arbóreo baixo $(\mathrm{Ab})(37,3 \%)$, que já sofreu forte alteração em sua estrutura e composição, em contraste com a baixa taxa de ocorrência de vegetação do tipo arbóreo alto (Aa) $(2,4 \%)$, que pouca alteração sofreu em sua estrutura e composição. Também observa-se uma alta taxa relativa de vegetação do tipo herbáceo à arbustivo $(H)(20,4 \%)$. 
Tabela 26. Ocorrência das classes morfológicas na área de estudo.

\begin{tabular}{|l|r|r|}
\hline Classe & \multicolumn{1}{|c|}{ Área $\left(\mathrm{m}^{2}\right)$} & \multicolumn{1}{c|}{$(\%)$} \\
\hline VCX (vertente convexa) & $10.748 .955,4$ & 10,0 \\
\hline VR (vertente retilínea) & $67.317 .119,8$ & 62,9 \\
\hline VCC (vertente convexa) & $84.131,7$ & 0,1 \\
\hline PF (planície fluvial) & $6.988 .358,9$ & 6,5 \\
\hline RC (rampa de colúvio) & $3.925 .241,3$ & 3,7 \\
\hline AT (área alterada) & $9.306 .956,2$ & 8,7 \\
\hline OUTROS_M & $8.699 .036,8$ & 8,1 \\
\hline total & $107.069 .800,0$ & 100,0 \\
\hline
\end{tabular}

Pelos dados da Tabela 26 observa-se que vertentes retilíneas (VR) $(62,9 \%)$ predominam na área de estudo. Nessas vertentes, o escoamento superficial ocorre preferencialmente concentrado, favorecendo processos erosivos.

Tabela 27. Ocorrência das classes litológicas na área de estudo.

\begin{tabular}{|l|r|r|}
\hline Classe $\left(^{*}\right)$ & Área $\left(\mathrm{m}^{2}\right)$ & \multicolumn{1}{|c|}{$(\%)$} \\
\hline Qc & $4.796 .145,4$ & 4,5 \\
\hline Qp & 0,0 & 0,0 \\
\hline Qb & $2.094 .857,7$ & 2,0 \\
\hline PSEOM & 0,0 & 0,0 \\
\hline PESOYt & $1.826 .541,9$ & 1,7 \\
\hline PSEOYm & $3.293 .214,2$ & 3,1 \\
\hline PSpF & $524.847,5$ & 0,5 \\
\hline PSpX & $33.156 .040,8$ & 31,0 \\
\hline PSpQ & 0,0 & 0,0 \\
\hline
\end{tabular}


(*) descrição das classes na Tabela 10.

Tabela 27. Ocorrência das classes litológicas na área de estudo.

\begin{tabular}{|l|r|r|}
\hline Classe $\left(^{*}\right)$ & \multicolumn{1}{|c|}{ Área $\left(\mathrm{m}^{2}\right)$} & \multicolumn{1}{c|}{$(\%)$} \\
\hline PSeMc & $5.408 .014,3$ & 5,1 \\
\hline AcMn & $28.098 .831,3$ & 26,2 \\
\hline AcMp & $8.089 .359,7$ & 7,6 \\
\hline AcMg & $36.258,9$ & 0,0 \\
\hline PSpC & $843.019,3$ & 0,8 \\
\hline OUTROS_L & $18.902 .668,9$ & 17,7 \\
\hline total & $107.069 .800,0$ & 100,0 \\
\hline
\end{tabular}

(*) descrição das classes na Tabela 10.

Conforme a Tabela 27, há duas formações litológicas predominantes na área de estudo, a de micaxistos (PSpX) $(31, \%)$ e a de migmatitos estromatíticos e ou oftalmíticos de neossoma dominante (AcMn) $(26,2 \%)$.

Tabela 28. Ocorrência das classes de precipitação média do trimestre mais chuvoso na área de estudo.

\begin{tabular}{|l|r|r|}
\hline Classe $(\mathrm{mm})$ & \multicolumn{1}{|c|}{ Área $\left(\mathrm{m}^{2}\right)$} & \multicolumn{1}{c|}{$(\%)$} \\
\hline $800-900$ & $22.500,3$ & 0,02 \\
\hline $900-1.000$ & $16.964 .306,0$ & 15,84 \\
\hline $1.000-1.100$ & $59.612 .223,8$ & 55,68 \\
\hline $1.100-1.200$ & $22.688 .375,5$ & 21,19 \\
\hline $1.200-1.300$ & $7.782 .394,5$ & 7,27 \\
\hline total & $107.069800,0$ & 100,00 \\
\hline
\end{tabular}

A Tabela 28 , mostra que a maior parte da área de estudo $(84,14 \%)$ tem sofrido uma precipitação média do trimestre mais chuvoso 
superior a $1.000 \mathrm{~mm}$, havendo uma maior distribuição dessa precipitação dentro da classe de $1.000 \mathrm{~mm}$ a $1.100 \mathrm{~mm}(55,68 \%)$. Esses índices de precipitação podem se considerados altos, visto que tiveram sua ocorrência concentrada em três meses contínuos, que corresponderam, em média, a $35,9 \%$ da precipitação total anual (IPT, 1985).

Tabela 29. Ocorrência das classes de precipitação média total anual na área de estudo.

\begin{tabular}{|l|r|r|}
\hline Classe $(\mathrm{mm})$ & \multicolumn{1}{c|}{ Área $\left(\mathrm{m}^{2}\right)$} & \multicolumn{1}{l|}{$(\%)$} \\
\hline $2.200-2.300$ & $2.700,0$ & 0,00 \\
$2.300-2.400$ & $8.100,1$ & 0,01 \\
$2.400-2.500$ & $10.800,1$ & 0,01 \\
$2.500-2.600$ & $1.319 .416,0$ & 1,23 \\
$2.600-2.700$ & $9.472 .615,0$ & 8,85 \\
$2.700-2.800$ & $8.849 .807,5$ & 8,27 \\
$2.800-2.900$ & $9.514 .015,5$ & 8,89 \\
$2.900-3.000$ & $11.969 .245,3$ & 11,18 \\
$3.000-3.100$ & $19.955 .042,3$ & 18,64 \\
$3.100-3.200$ & $10.830 .731,5$ & 10,12 \\
$3.200-3.300$ & $9.032 .509,7$ & 8,44 \\
$3.300-3.400$ & $6.315 .376,7$ & 5,90 \\
$3.400-3.500$ & $4.578 .355,6$ & 4,28 \\
$3.500-3.600$ & $4.116 .650,0$ & 3,84 \\
$3.600-3.700$ & $3.922 .247,6$ & 3,66 \\
$3.700-3.800$ & $3.225 .639,2$ & 3,01 \\
$3.800-3.900$ & $2.557 .831,1$ & 2,39 \\
$3.900-4.000$ & $1.388 .716,9$ & 1,30 \\
\hline total & $107.069 .800,0$ & 100,00 \\
\hline
\end{tabular}


Os dados da Tabela 29 mostram que a precipitação média total anual da área de estudo, ocorreu predominantemente entre $2.900 \mathrm{~mm}$ e 3.200 $\mathrm{mm}$, cobrindo $39,94 \%$ da mesma. Esses índices estão acima da precipitação total média do período em que esses dados se basearam (1953 a 1983), que foi de $2.626 \mathrm{~mm}$ (IPT, 1985).

A área de estudo apresenta-se com características de relevo hipsométricas, clinográficas e de exposição de vertentes, favoráveis a ocorrência de escorregamentos, que no caso da duas últimas, ocorrem predominantemente. Quanto aos seus componentes físicos, os solos predominantes, latossolos vermelho-amarelo, encontram-se sob uma cobertura vegetal, na sua maior parte de porte arbóreo baixo, com forte alteração, deixando-o mais desprotegidos contra a ação das precipitações, que, na maior parte da área de estudo, atingem índices médios superiores a $1.000 \mathrm{~mm}$, no trimestre mais chuvoso. Associa-se ainda a esses fatos a morfologia predominante das vertentes, retilinea, e propicia o surgimento de escoamento pluvial concentrado. Tem-se, então, um quadro da instabilidade, quanto aos fatores naturais, que é agravado pela ocupação humana na região.

\subsection{Características das áreas com escorregamento}

Para uma caracterização das áreas com escorregamento, analisou-se a ocorrência das classes de cada fator de instabilidade, conforme é mostrado nas Tabelas $30,31,32,33,34,35,36,37,38$ e 39 . 
Tabela 30. Ocorrência das classes de superfície nas áreas com escorregamento.

\begin{tabular}{|l|r|r|}
\hline Classe $\left(\mathrm{m}^{2}\right)$ & Área $\left(\mathrm{m}^{2}\right)$ & \multicolumn{1}{|c|}{$(\%)$} \\
\hline $0-1.000$ & $277.931,9$ & 29,5 \\
\hline $1.000-2.000$ & $364.785,6$ & 38,7 \\
\hline $2.000-3.000$ & $123.766,6$ & 13,1 \\
\hline $3.000-4.000$ & $69.483,0$ & 7,4 \\
\hline $4.000-5.000$ & $30.398,8$ & 3,2 \\
\hline $5.000-6.000$ & $30.398,8$ & 3,2 \\
\hline $6.000-7.000$ & $13.028,1$ & 1,4 \\
\hline $7.000-8.000$ & $2.171,3$ & 0,2 \\
\hline $8.000-9.000$ & $6.514,0$ & 0,7 \\
\hline $9.000-10.000$ & $2.171,3$ & 0,2 \\
\hline $10.000-11.000$ & $2.171,3$ & 0,2 \\
\hline $11.000-12.000$ & $2.171,3$ & 0,2 \\
\hline $12.000-13.000$ & $4.342,7$ & 0,5 \\
\hline $13.000-14.000$ & $4.342,7$ & 0,5 \\
\hline $14.000-15.000$ & $4.342,7$ & 0,5 \\
\hline $15.000-16.000$ & $2.171,3$ & 0,2 \\
\hline $16.000-17.000$ & 0,0 & 0,0 \\
\hline $17.000-18.000$ & 0,0 & 0,0 \\
\hline $18.000-19.000$ & 0,0 & 0,0 \\
\hline $19.000-20.000$ & 0,0 & 0,0 \\
\hline $20.000-21.000$ & 0,0 & 0,0 \\
\hline $21.000-22.000$ & 0,0 & 0,0 \\
\hline $22.000-23.000$ & 0,0 & 0,0 \\
\hline $23.000-24.000$ & $2.171,3$ & 0,2 \\
\hline total & $942.362,9$ & 100,0 \\
\hline & & \\
\hline 100 & 0.0 & 0.0 \\
\hline
\end{tabular}


A Tabela 30 mostra que $68,2 \%$ dos escorregamentos possuíam áreas entre $0 \mathrm{~m}^{2}$ e $2.000 \mathrm{~m}^{2}$.

Tabela 31. Ocorrência das classes hipsométricas nas áreas com escorregamento.

\begin{tabular}{|l|r|r|}
\hline Classe $(\mathrm{m})$ & \multicolumn{1}{|c|}{ Área $\left(\mathrm{m}^{2}\right)$} & \multicolumn{1}{c|}{$(\%)$} \\
\hline $0-100$ & 0,0 & 0,0 \\
\hline $100-300$ & $210.620,3$ & 22,4 \\
\hline $300-500$ & $290.960,0$ & 30,9 \\
\hline $500-700$ & $280.103,3$ & 29,7 \\
\hline $700-900$ & $156.336,7$ & 16,6 \\
\hline $900-1.100$ & $4.342,7$ & 0,5 \\
\hline total & $942.362,9$ & 100,0 \\
\hline
\end{tabular}

Observa-se, na Tabela 31, que a maior incidência de áreas com escorregamento ocorreu na média encosta $(30,9 \%)$, entre $300 \mathrm{~m}$ e $500 \mathrm{~m}$ de altitude, e na alta encosta (46,87\%), acima de $500 \mathrm{~m}$ de altitude.

Tabela 32. Ocorrência das Classes clinográficas nas áreas com escorregamento.

\begin{tabular}{|l|r|r|}
\hline classe $\left(^{\circ}\right)$ & área $\left(\mathrm{m}^{2}\right)$ & \multicolumn{1}{c|}{$(\%)$} \\
\hline $0^{\circ}-7^{\circ}$ & $13.028,1$ & 1,4 \\
\hline $7^{\circ}-17^{\circ}$ & $97.710,4$ & 10,4 \\
\hline $17^{\circ}-25^{\circ}$ & $314.844,7$ & 33,4 \\
\hline $25^{\circ}-36^{\circ}$ & $447.296,7$ & 47,5 \\
\hline $36^{\circ}-45^{\circ}$ & $67.311,6$ & 7,1 \\
\hline$>45^{\circ}$ & $2.171,3$ & 0,2 \\
\hline total & $942.362,9$ & 100,0 \\
\hline
\end{tabular}


Como é mostrado na Tabela 32, as áreas com escorregamento ocorreram em sua maior parte em altas declividades, sendo $47,5 \%$ entre $25^{\circ} \mathrm{e}$ $36^{\circ}$ e $33,4 \%$ entre $17^{\circ}$ e $25^{\circ}$.

Tabela 33. Ocorrência das classes de exposição de vertentes nas áreas com escorregamento.

\begin{tabular}{|l|r|r|}
\hline Classe & \multicolumn{1}{|c|}{ Área $\left(\mathrm{m}^{2}\right)$} & \multicolumn{1}{|c|}{$(\%)$} \\
\hline N (norte) & $8.685,4$ & 0,9 \\
\hline NE (nordeste) & $73.825,7$ & 7,8 \\
\hline L (leste) & $238.847,7$ & 25,3 \\
\hline SE (sudeste) & $232.333,7$ & 24,7 \\
\hline S (sul) & $141.137,3$ & 15,0 \\
\hline SO (oeste) & $97.710,4$ & 10,4 \\
\hline O (oeste) & $56.454,9$ & 6,0 \\
\hline NO (noroeste) & $93.367,8$ & 9,9 \\
\hline total & $942.362,9$ & 100,0 \\
\hline
\end{tabular}

$\mathrm{Na}$ Tabela 33, observa-se que as áreas com escorregamento predominaram em vertentes com orientação leste (L) $(25,3 \%)$ e sudeste (SE) $(24,7 \%)$. Como já foi visto, vertentes com orientação sudeste (SE) predominam na área de estudo. 
Tabela 34. Ocorrência das classes pedológicas nas áreas com escorregamento.

\begin{tabular}{|l|r|r|}
\hline Classe $\left(^{*}\right)$ & Área $\left(\mathrm{m}^{2}\right)$ & \multicolumn{1}{|c|}{$(\%)$} \\
\hline $\mathrm{LVa}_{1}$ & $637.984,6$ & 67,7 \\
\hline $\mathrm{LVa}_{2}$ & 0,0 & 0,0 \\
\hline $\mathrm{LVa}_{3}$ & $164.817,7$ & 17,5 \\
\hline $\mathrm{Ca}_{1}$ & $13.437,4$ & 1,4 \\
\hline $\mathrm{Ca}_{2}$ & $19.808,8$ & 2,1 \\
\hline $\mathrm{Ca}_{3}$ & $106.314,3$ & 11,3 \\
\hline $\mathrm{A}$ & 0,0 & 0,0 \\
\hline SM & 0,0 & 0,0 \\
\hline OUTROS_S & 0,0 & 0,0 \\
\hline total & $942.362,9$ & 100,0 \\
\hline
\end{tabular}

(*) descrição das classes na Tabela 7.

Os dados da Tabela 34, mostram que áreas com escorregamento ocorreram predominantemente na classe pedológica de latossolo vermelhoamarelo $\mathrm{LVa}_{1}(67,7 \%)$. Ressalta-se o fato de que na classe pedológica de latossolo vermelho-amarelo $\mathrm{LVa}_{3}$, que ocorre na maior parte da área de estudo, a ocorrência de áreas com escorregamento foi baixa $(17,5 \%)$ em relação a primeira, enquanto que na classe pedológica de cambissolo associado a solo litólico $\mathrm{Ca}_{3}$, que ocorre em apenas $2,6 \%$ da área de estudo, observou-se uma ocorrência de $11,3 \%$ de áreas com escorregamento. Cambissolos apresentamse mais suscetíveis à erosão quando são rasos e encontram-se em altas declividades. 
Tabela 35. Ocorrência das classes de cobertura vegetal nas áreas com escorregamento.

\begin{tabular}{|l|r|r|}
\hline Classe & \multicolumn{1}{|c|}{ Área $\left(\mathrm{m}^{2}\right)$} & \multicolumn{1}{|c|}{ (\%) } \\
\hline Aa (arbóreo alto) & 0,0 & 0,0 \\
\hline Am (arbóreo médio) & $122.635,8$ & 13,0 \\
\hline Ab (arbóreo baixo) & $581.253,2$ & 61,7 \\
\hline AlA (arbóreo à arbustivo) & $146.516,9$ & 15,5 \\
\hline H (herbáceo à arbustivo) & $53.105,0$ & 5,6 \\
\hline Mg (mangue) & 0,0 & 0,0 \\
\hline E (reflorestamento) & 0,0 & 0,0 \\
\hline SN (solo nu) & 0,0 & 0,0 \\
\hline OUTROS_V & $38.852,0$ & 4,1 \\
\hline total & $942.362,9$ & 100,0 \\
\hline
\end{tabular}

$\mathrm{Na}$ Tabela 35 observa-se que áreas com escorregamento ocorreram predominantemente em áreas com cobertura vegetal do tipo arbóreo baixo $(A b)(61,7 \%)$, seguida por áreas com cobertura vegetal do tipo arbóreo à arbustivo (A/A) (15,5\%). Ressalta-se que a maior taxa de áreas com escorregamento ocorreu em uma cobertura vegetal que sofreu forte alteração na sua estrutura e composição e em cobertura vegetal de pequeno porte de origem natural ou não, indicando uma correlação direta entre a ocorrência de processos erosivos com o estado de alteração da cobertura vegetal. 
Tabela 36. Ocorrência das classes morfológicas nas áreas com escorregamento.

\begin{tabular}{|l|r|r|}
\hline Classe & Área $\left(\mathrm{m}^{2}\right)$ & \multicolumn{1}{c|}{$(\%)$} \\
\hline VCX (vertente convexa) & $179.842,0$ & 19,1 \\
\hline VR (vertente retilínea) & $762.521,0$ & 80,9 \\
\hline VCC (vertente convexa) & 0,0 & 0,0 \\
\hline PF (planície fluvial) & 0,0 & 0,0 \\
\hline RC (rampa de colúvio) & 0,0 & 0,0 \\
\hline AT (área alterada) & 0,0 & 0,0 \\
\hline OUTROS_M & 0,0 & 0,0 \\
\hline total & $942.362,9$ & 100,0 \\
\hline
\end{tabular}

Pelos dados da Tabela 36 observa-se que áreas com escorregamento ocorreram predominantemente em vertentes retilíneas (VR) $(80,9 \%)$, que predominam na área de estudo.

Tabela 37. Ocorrência das classes litológicas nas áreas com escorregamento.

\begin{tabular}{|l|r|r|}
\hline Classe $\left(^{*}\right)$ & Área $\left(\mathrm{m}^{2}\right)$ & \multicolumn{1}{|c|}{$(\%)$} \\
\hline Qc & 0,0 & 0,0 \\
\hline Qp & 0,0 & 0,0 \\
\hline Qb & 0,0 & 0,0 \\
\hline PSEOM & 0,0 & 0,0 \\
\hline PSEOYt & 0,0 & 0,0 \\
\hline PSEOYm & $43.394,7$ & 4,6 \\
\hline PSpF & $2.192,3$ & 0,2 \\
\hline PSpX & $247.668,5$ & 26,3 \\
\hline PSpQ & 0,0 & 0,0 \\
\hline
\end{tabular}

(*) descrição das classes na Tabela 10. 
Tabela 37. Ocorrência das classes litológicas nas áreas com escorregamento.

\begin{tabular}{|l|r|r|}
\hline Classe $\left(^{*}\right)$ & \multicolumn{1}{|c|}{ Área $\left(\mathrm{m}^{2}\right)$} & \multicolumn{1}{c|}{$(\%)$} \\
\hline PSeMc & $122.248,7$ & 13,0 \\
\hline AcMn & $439.024,4$ & 46,6 \\
\hline AcMp & $87.834,2$ & 9,3 \\
\hline AcMg & 0,0 & 0,0 \\
\hline PSpC & 0,0 & 0,0 \\
\hline OUTROS_L & 0,0 & 0,0 \\
\hline total & $942.362,9$ & 100,0 \\
\hline
\end{tabular}

$\left.{ }^{*}\right)$ descrição das classes na Tabela 10.

Conforme a Tabela 37, áreas com escorregamento ocorreram com maior incidência em áreas com formação litológica de migmatitos estromatíticos e ou oftalmíticos de neossoma dominante (AcMn) $(46,6 \%)$ e em áreas com formação litológica de micaxistos (PSpX) $(26,3, \%)$, que são as duas predominantes na área de estudo.

Tabela 38. Ocorrência das classes de precipitação média do trimestre mais chuvoso nas áreas com escorregamento.

\begin{tabular}{|l|r|r|}
\hline Classe $(\mathrm{mm})$ & \multicolumn{1}{|c|}{ Área $\left(\mathrm{m}^{2}\right)$} & \multicolumn{1}{c|}{$(\%)$} \\
\hline $900-1.000$ & $2.171,3$ & 0,2 \\
\hline $1.000-1.100$ & $382.156,4$ & 40,6 \\
\hline $1.100-1.200$ & $397.355,8$ & 42,2 \\
\hline $1.200-1.300$ & $160.679,4$ & 17,1 \\
\hline total & $942.362,9$ & 100,0 \\
\hline
\end{tabular}

A Tabela 38, mostra que áreas com escorregamento ocorreram predominantemente $(82,2 \%)$ onde a precipitação média do trimestre mais 
chuvoso apresentou-se entre $1.000 \mathrm{~mm}$ e $1.200 \mathrm{~mm}$. Esse intervalo de precipitação média do trimestre mais chuvoso foi o predominante na área de estudo e sendo a precipitação um agente deflagrador de processos erosivos, fica bem indicada a correlação entre altos índices pluviométricos e a ocorrência de escorregamentos.

Tabela 39. Ocorrência das classes de precipitação média total anual nas áreas com escorregamento.

\begin{tabular}{|l|r|r|}
\hline Classe $(\mathrm{mm})$ & Área $\left(\mathrm{m}^{2}\right)$ & \multicolumn{1}{|c|}{ (\%) } \\
\hline $2.800-2.900$ & $28.227,5$ & 3,0 \\
\hline $2.900-3.000$ & $49.940,9$ & 5,3 \\
\hline $3.000-3.100$ & $115.081,2$ & 12,2 \\
\hline $3.100-3.200$ & $110.738,5$ & 11,8 \\
\hline $3.200-3.300$ & $143.308,6$ & 15,2 \\
\hline $3.300-3.400$ & $93.367,8$ & 9,9 \\
\hline $3.400-3.500$ & $73.825,7$ & 7,8 \\
\hline $3.500-3.600$ & $115.081,2$ & 12,2 \\
\hline $3.600-3.700$ & $69.483,0$ & 7,4 \\
\hline $3.700-3.800$ & $39.084,2$ & 4,1 \\
\hline $3.800-3.900$ & $34.741,5$ & 3,7 \\
\hline $3.900-4.000$ & $69.483,0$ & 7,4 \\
\hline total & $942.362,9$ & 100,0 \\
\hline
\end{tabular}

Conforme a Tabela 39, áreas com escorregamento ocorreram mais concentradas $(39,2 \%)$ onde a precipitação média total anual apresentouse entre $3.000 \mathrm{~mm}$ e $3.300 \mathrm{~mm}$, destacando-se também uma ocorrência significativa entre $3.500 \mathrm{~mm}$ e $3.600 \mathrm{~m}(12,2 \%)$. Essa observação concorda com os intervalos de precipitação média total anual de maior ocorrência na área de estudo. 
As características das áreas com escorregamento, confirmam as observações feitas quanto as condições de instabilidade da área de estudo, pois estas ocorreram, predominantemente, na média e alta encosta, em altas declividades, em vertentes de orientação leste e sudeste, em latossolo vermelho-amarelo, em cobertura vegetal de porte arbóreo baixo com forte alteração, em vertentes retilíneas, em litologia de migmatitos estromatíticos e em áreas com precipitação média do trimestre mais chuvoso superior a 1.000 $\mathrm{mm}$.

\subsection{Características das áreas sem escorregamento}

Para uma caracterização das áreas sem escorregamento, analisou-se a ocorrência das classes de cada fator de instabilidade, conforme é mostrado nas Tabelas 40, 41, 42, 43, 44, 45, 46, 47 e 48.

A ocorrência das classes de superfície nas áreas sem escorregamento apresenta a distribuição de suas classes similar a de áreas com escorregamento. Isso se deve pelo fato de que as áreas sem escorregamento, originaram-se do deslocamento das áreas com escorregamento, dentro da área de estudo, para locais onde não haviam sido registrados escorregamentos no período analisado. 
Tabela 40. Ocorrência das classes hipsométricas nas áreas sem escorregamento.

\begin{tabular}{|l|r|r|}
\hline Classe $(\mathrm{m})$ & Área $\left(\mathrm{m}^{2}\right)$ & \multicolumn{1}{c|}{$(\%)$} \\
\hline $0-100$ & $110.372,4$ & 11,8 \\
$100-300$ & $318.132,3$ & 33,9 \\
$300-500$ & $244.550,7$ & 26,1 \\
$500-700$ & $222.909,0$ & 23,8 \\
$700-900$ & $41.119,1$ & 4,4 \\
$900-1.100$ & 0,0 & 0,0 \\
\hline total & $937.083,5$ & 100,0 \\
\hline
\end{tabular}

Observa-se, na Tabela 40, que a maior incidência de áreas sem escorregamento se deu na baixa encosta $(33,9 \%)$, entre $100 \mathrm{~m}$ e $300 \mathrm{~m}$ de altitude, na média encosta (26,19\%), entre $300 \mathrm{~m}$ e $500 \mathrm{~m}$ de altitude, e na alta encosta $(23,8 \%)$, entre $500 \mathrm{~m}$ e $700 \mathrm{~m}$ de altitude.

Tabela 41. Ocorrência das classes clinográficas nas áreas sem escorregamento.

\begin{tabular}{|l|r|r|}
\hline Classe $\left(^{\circ}\right)$ & \multicolumn{1}{|c|}{ Área $\left(\mathrm{m}^{2}\right)$} & \multicolumn{1}{|c|}{$(\%)$} \\
\hline $0^{\circ}-7^{\circ}$ & $4.328,3$ & 0,5 \\
\hline $7^{\circ}-17^{\circ}$ & $194.774,9$ & 20,8 \\
\hline $17^{\circ}-25^{\circ}$ & $404.698,9$ & 43,2 \\
\hline $25^{\circ}-36^{\circ}$ & $311.639,8$ & 33,3 \\
\hline $36^{\circ}-45^{\circ}$ & $21.641,7$ & 2,3 \\
\hline$>45^{\circ}$ & 0,0 & 0,0 \\
\hline total & $937.083,5$ & 100,0 \\
\hline
\end{tabular}


Como é mostrado na Tabela 41, as áreas sem escorregamento ocorreram em sua maior parte $(43,2 \%)$ em declividades entre $17^{\circ}$ e $25^{\circ}$, ocorrendo também em altas declividades $(33,3 \%)$, entre $25^{\circ}$ e $36^{\circ}$.

Tabela 42. Ocorrência das classes de exposição e vertentes nas áreas sem escorregamento.

\begin{tabular}{|l|r|r|}
\hline Classe & \multicolumn{1}{|c|}{ Área $\left(\mathrm{m}^{2}\right)$} & \multicolumn{1}{c|}{$(\%)$} \\
\hline N (norte) & $8.656,7$ & 0,9 \\
\hline NE (nordeste) & $36.790,8$ & 3,9 \\
\hline L (leste) & $64.925,0$ & 6,9 \\
\hline SE (sudeste) & $242.386,5$ & 25,9 \\
\hline S (sul) & $220.744,8$ & 23,6 \\
\hline SO (sudoeste) & $67.089,1$ & 7,2 \\
\hline O (oeste) & $147.163,2$ & 15,7 \\
\hline NO (noroeste) & $149.327,4$ & 15,9 \\
\hline total & $937.083,5$ & 100,0 \\
\hline
\end{tabular}

$\mathrm{Na}$ Tabela 42, observa-se que as áreas sem escorregamento predominaram em vertentes com orientação sudeste (SE) $(25,9 \%)$ e sul (S) $(23,6 \%)$. 
Tabela 43. Ocorrência das classes pedológicas nas áreas sem escorregamento.

\begin{tabular}{|l|r|r|}
\hline Classe $\left(^{*}\right)$ & Área $\left(\mathrm{m}^{2}\right)$ & \multicolumn{1}{|c|}{$(\%)$} \\
\hline $\mathrm{LVa}_{1}$ & $528.104,2$ & 56,0 \\
\hline $\mathrm{LVa}_{2}$ & 0,0 & 0,0 \\
\hline $\mathrm{LVa}_{3}$ & $335.841,1$ & 36,0 \\
\hline $\mathrm{Ca}_{1}$ & $9.816,1$ & 1,0 \\
\hline $\mathrm{Ca}_{2}$ & $28.133,1$ & 3,0 \\
\hline $\mathrm{Ca}_{3}$ & $33.194,8$ & 4,0 \\
\hline $\mathrm{A}$ & 246,3 & 0,0 \\
\hline SM & 0,0 & 0,0 \\
\hline OUTROS_S & $1.747,9$ & 0,0 \\
\hline total & $937.083,5$ & 100,0 \\
\hline
\end{tabular}

${ }^{(*)}$ descrição da classes na Tabela 7.

Os dados da Tabela 43, mostram que áreas sem escorregamento ocorreram predominantemente na classe pedológica de latossolo vermelhoamarelo $\mathrm{LVa}_{1}(56,0 \%)$. Ressalta-se o fato de que na classe pedológica de latossolo vermelho-amarelo $\mathrm{LVa}_{3}$, que ocorre na maior parte da área de estudo, a ocorrência de áreas sem escorregamento $(36,0 \%)$ foi superior a ocorrência de áreas com escorregamento $(17,5 \%)$. 
Tabela 44. Ocorrência das classes de cobertura vegetal nas áreas sem escorregamento.

\begin{tabular}{|l|r|r|}
\hline Classe & \multicolumn{1}{|c|}{ Área $\left(\mathrm{m}^{2}\right)$} & \multicolumn{1}{|c|}{ (\%) } \\
\hline Aa (arbóreo alto) & $40.268,2$ & 4,0 \\
\hline Am (arbóreo médio) & $208.898,2$ & 22,0 \\
\hline Ab (arbóreo baixo) & $419.092,8$ & 45,0 \\
\hline AlA (arbóreo à arbustivo) & $96.647,6$ & 10,0 \\
\hline H (herbáceo à arbustivo) & $114.757,8$ & 12,0 \\
\hline Mg (mangue) & 0,0 & 0,0 \\
\hline E (reflorestamento) & $5.034,4$ & 1,0 \\
\hline SN (solo nu) & $1.270,7$ & 0,0 \\
\hline OUTROS_V & $51.113,7$ & $5,0^{\prime}$ \\
\hline Total & $937.083,5$ & 100,0 \\
\hline
\end{tabular}

$\mathrm{Na}$ Tabela 44 observa-se que a áreas sem escorregamento ocorreram predominantemente em áreas com cobertura vegetal do tipo arbóreo baixo $(\mathrm{Ab})(45,0 \%)$, ocorrendo também com cobertura vegetal do tipo arbóreo médio $(22,0 \%)$. 
Tabela 45. Ocorrência das classes morfológicas nas áreas sem escorregamento.

\begin{tabular}{|l|r|r|}
\hline classe & Área $\left(\mathrm{m}^{2}\right)$ & \multicolumn{1}{c|}{$(\%)$} \\
\hline VCX (vertente convexa) & $131.484,6$ & 14,0 \\
\hline VR (vertente retilinea) & $761.767,2$ & 81,0 \\
\hline VCC (vertente convexa) & 0,0 & 0,0 \\
\hline PF (planície fluvial) & 0,0 & 0,0 \\
\hline RC (rampa de colúvio) & $23.893,0$ & 3,0 \\
\hline AT (área alterada) & $18.349,3$ & 2,0 \\
\hline OUTROS_M & $1.589,4$ & 0,0 \\
\hline total & $937.083,5$ & 100,0 \\
\hline
\end{tabular}

Pelos dados da Tabela 45 observa-se que áreas sem escorregamento ocorreram predominantemente em vertentes retilíneas (VR) $(81,0 \%)$, que são as predominantes na área de estudo.

Tabela 46. Ocorrência das classes litológicas nas áreas sem escorregamento.

\begin{tabular}{|l|r|r|}
\hline Classe $\left(^{*}\right)$ & Área $\left(\mathrm{m}^{2}\right)$ & \multicolumn{1}{|c|}{ (\%) } \\
\hline Qc & 0,0 & 0,0 \\
\hline Qp & 0,0 & 0,0 \\
\hline Qb & 0,0 & 0,0 \\
\hline PSEOM & 0,0 & 0,0 \\
\hline PSEOYt & $48.432,4$ & 5,0 \\
\hline PSEOYm & $67.714,0$ & 7,0 \\
\hline PSpF & $9.387,0$ & 1,0 \\
\hline PSpX & $287.784,7$ & 31,0 \\
\hline PSpQ & 0,0 & 0,0 \\
\hline
\end{tabular}

${ }^{*}$ ) descrição das classes na Tabela 10. 
Tabela 46. Ocorrência das classes litológicas nas áreas sem escorregamento.

\begin{tabular}{|l|r|r|}
\hline Classe $\left(^{*}\right)$ & Área $\left(\mathrm{m}^{2}\right)$ & \multicolumn{1}{|c|}{$(\%)$} \\
\hline PSeMc & $56.322,4$ & 6,0 \\
\hline AcMn & $268.141,8$ & 29,0 \\
\hline AcMp & $156.221,8$ & 17,0 \\
\hline AcMg & 0,0 & 0,0 \\
\hline PSpC & $20.646,3$ & 2,0 \\
\hline OUTROS_L & $22.433,1$ & 2,0 \\
\hline total & $937.083,5$ & 100,0 \\
\hline
\end{tabular}

(*) descrição das classes na Tabela 10.

Conforme a Tabela 46, áreas sem escorregamento ocorreram com maior incidência em áreas com formação litológica de micaxistos (PSpX) $(31,0 \%)$ e com formação litológica de migmatitos estromatíticos e ou oftalmíticos de neossoma dominante $(A c M n)(29,0 \%)$, que são as duas predominantes na área de estudo

Tabela 47. Ocorrência das classes de precipitação média do trimestre mais chuvoso nas áreas sem escorregamento.

\begin{tabular}{|l|r|r|}
\hline Classe $(\mathrm{mm})$ & \multicolumn{1}{|c|}{ Área $\left(\mathrm{m}^{2}\right)$} & \multicolumn{1}{|c|}{$(\%)$} \\
\hline $900-1.000$ & $47.611,6$ & 5,1 \\
\hline $1.000-1.100$ & $567.011,3$ & 60,5 \\
\hline $1.100-1.200$ & $251.043,2$ & 26,8 \\
\hline $1.200-1.300$ & $71.417,4$ & 7,6 \\
\hline total & $937.083,5$ & 100,0 \\
\hline
\end{tabular}


A Tabela 47, mostra que áreas sem escorregamento ocorreram predominantemente $(60,52 \%)$ entre $1.000 \mathrm{~mm}$ e $1.100 \mathrm{~mm}$ de precipitação média do trimestre mais chuvoso.

Tabela 48. Ocorrência das classes de precipitação média total anual nas áreas sem escorregamento.

\begin{tabular}{|l|r|r|}
\hline Classe $(\mathrm{mm})$ & \multicolumn{1}{|c|}{ Área $\left(\mathrm{m}^{2}\right)$} & \multicolumn{1}{c|}{$(\%)$} \\
\hline $2.600-2.700$ & $19.477,5$ & 2,1 \\
\hline $2.700-2.800$ & $30.298,3$ & 3,2 \\
\hline $2.800-2.900$ & $54.104,1$ & 5,8 \\
\hline $2.900-3.000$ & $75.745,8$ & 8,1 \\
\hline $3.000-3.100$ & $218.580,7$ & 23,3 \\
\hline $3.100-3.200$ & $173.133,2$ & 18,5 \\
\hline $3.200-3.300$ & $95.223,3$ & 10,2 \\
\hline $3.300-3.400$ & $69.253,3$ & 7,4 \\
\hline $3.400-3.500$ & $47.611,6$ & 5,1 \\
\hline $3.500-3.600$ & $47.611,6$ & 5,1 \\
\hline $3.600-3.700$ & $43.283,3$ & 4,6 \\
\hline $3.700-3.800$ & $25.970,0$ & 2,8 \\
$3.800-3.900$ & $28.134,1$ & 3,0 \\
$3.900-4.000$ & $8.656,7$ & 0,9 \\
\hline total & $937.083,5$ & 100,0 \\
\hline
\end{tabular}

Conforme a Tabela 48, áreas sem escorregamento ocorreram mais concentradas $(41,8 \%)$ onde a precipitação média total anual apresentouse entre $3.000 \mathrm{~mm}$ e $3.200 \mathrm{~mm}$, que concorda com os intervalos de precipitação média total anual de maior ocorrência na área de estudo.

Áreas sem escorregamento, ocorreram com maior freqüência, do que as áreas com escorregamento, na baixa e média encosta, em declividades 
inferiores a $17^{\circ}$ e em cobertura vegetal do tipo arbóreo médio e alto. Ocorreram predominantemente em vertentes de orientação sudeste e sul, em latossolo vermelho-amarelo, em vertentes retilíneas, em litologia de micaxistos e migmatitos estromatíticos e em áreas com precipitação média do trimestre mais chuvoso inferior a $1.100 \mathrm{~mm}$.

\subsection{Função discriminante}

Primeiramente foi utilizada a amostra de análise para a construção da função discriminante. $\mathrm{Na}$ Tabela 49, são dadas informações sobre os dois grupos analisados, como suas freqüências, pesos, proporções e probabilidades prévias.

Tabela 49. Freqüências, pesos, proporções e probabilidades prévias dos grupos analisados.

\begin{tabular}{|lcccc|}
\hline & & & \multicolumn{2}{c|}{ Probabilidade } \\
\hline Grupo & Freqüência & Peso & Proporção & Prévia \\
\hline área com escorregamento & 325 & 325,0 & 0,500770 & $50,0 \%$ \\
área sem escorregamento & 324 & 324,0 & 0,499230 & $50,0 \%$ \\
\hline
\end{tabular}

Das 45 variáveis medidas para cada amostra, as 34 variáveis que melhor discriminam os grupos foram selecionadas para a construção da função discriminante, e para cada uma delas foi atribuído um peso dentro de cada grupo considerado. As 11 variáveis eliminadas, que foram as consideradas que pouco contribuíram para a discriminação entre os grupos, foram as pedológicas de latossolo vermelho-amarelo $\left(\mathrm{LVa}_{2}\right)$ e de solo de mangue (SM), a de cobertura vegetal de mangue $(\mathrm{Mg})$, as morfológicas de vertentes côncavas 
(VCC) e de planície fluvial (PF) e as litológicas de sedimentos de granulometria muito variada $(Q c)$, de areias e argilas ricas em fragmentos vegetais ( $Q p$ e $Q b$ ), de faixa cataclástica em parte recristalizadas e com oftalmogênese superposta (PSEOM), de quartzitos puros (PSpQ) e de oftalmitos anatexíticos (AcMg).

Dessa forma, a função discriminante obtida, para área com e sem escorregamentos, foi:

$\mathbf{Z}=\mathbf{C}($ constante $)+\mathbf{X}_{1}{ }^{*}$ (hipsometria $)+\mathbf{X}_{2}{ }^{*}$ (clinometria $)+\mathbf{X}_{3}{ }^{*}$ (exposição de vertente $)+\mathbf{X}_{4}{ }^{*}$ (precipitação média do trimestre mais chuvoso $)+\mathbf{X}_{5}$ * (precipitação média total anual) $+\mathbf{X}_{6}{ }^{*}\left(\mathrm{LVa}_{1}\right)+\mathbf{X}_{7}{ }^{*}\left(\mathrm{LVa}_{3}\right)+\mathrm{X}_{8}{ }^{*}\left(\mathrm{Ca}_{1}\right)+\mathbf{X}_{9}$ ${ }^{*}\left(\mathrm{Ca}_{2}\right)+\mathbf{X}_{10}{ }^{*}\left(\mathrm{Ca}_{3}\right)+\mathbf{X}_{11}{ }^{*}(\mathrm{~A})+\mathbf{X}_{12}{ }^{*}$ (OUTROS_S $)+\mathbf{X}_{13}{ }^{*}$ (PSEOYt) $+\mathbf{X}_{14}$ ${ }^{*}($ PSEYm $)+X_{15}{ }^{*}(P S p F)+X_{16}{ }^{*}(P S p X)+X_{17}{ }^{*}(P S e M c) X_{18}{ }^{*}($ AcMn $)+X_{19}{ }^{*}$ $(A C M P)+X_{20} *(P S p C)+X_{21} *\left(O U T R O S \_L\right)+X_{22} *(V C X)+X_{23} *(V R)+X_{24}$ * $(R C)+X_{25}$ * (AT) $+X_{26}$ * (OUTROS_M) $+X_{27}$ *(Aa) $+X_{28}$ * (Am) $+X_{29}$ * $(A b)+X_{30}{ }^{*}(A / A)+X_{31} *(H)+X_{32} *(E)+X_{33} *(S N)+X_{34} *$ (OUTROS_V)

Os valores dos coeficientes da função discriminante para áreas com e sem escorregamento, são mostrados na Tabela 50. A descrição das variáveis presentes na função discriminante encontra-se na Tabela 7 para as de pedologia $\left(X_{6}\right.$ a $\left.X_{12}\right)$, na Tabela 8 para as de cobertura vegetal $\left(X_{27}\right.$ a $\left.X_{34}\right)$, na Tabela 9 para as de morfologia $\left(X_{22}\right.$ a $\left.X_{26}\right)$ e na Tabela 10 para as de litologia $\left(X_{13}\right.$ a $\left.X_{21}\right)$. 
Tabela 50. Valores dos coeficientes da função discriminante para áreas com e sem escorregamento.

\begin{tabular}{|c|c|c|c|c|c|}
\hline $\begin{array}{l}\text { Coefici- } \\
\text { entes }\end{array}$ & $\begin{array}{l}\text { Áreas com } \\
\text { Escorrega- } \\
\text { mento }\end{array}$ & $\begin{array}{l}\text { Áreas sem } \\
\text { Escorrega- } \\
\text { mento }\end{array}$ & $\begin{array}{l}\text { Coefici- } \\
\text { entes }\end{array}$ & $\begin{array}{c}\text { Áreas com } \\
\text { Escorrega- } \\
\text { mento }\end{array}$ & $\begin{array}{c}\text { Areas sem } \\
\text { Escorrega- } \\
\text { mento }\end{array}$ \\
\hline C & -5.949 .544 & -5.949 .244 & $X_{18}$ & 3.402 .382 & 3.402 .583 \\
\hline$X_{1}$ & $-3,48122$ & $-3,48354$ & $X_{19}$ & 3.402 .265 & 3.402 .466 \\
\hline$X_{2}$ & 45,28814 & 45,26513 & $X_{20}$ & 3.400 .870 & 3.401 .072 \\
\hline$X_{3}$ & $-2,65508$ & $-2,65274$ & $x_{21}$ & 3.402 .548 & 3.402 .749 \\
\hline$X_{4}$ & 2,77256 & 2,75777 & $x_{22}$ & 568.145 & 568.224 \\
\hline$X_{5}$ & $-0,47848$ & $-0,47837$ & $X_{23}$ & 568.173 & 568.253 \\
\hline$X_{6}$ & 7.041 .756 & 7.041 .254 & $x_{24}$ & 567.411 & 567.493 \\
\hline$x_{7}$ & 7.041 .775 & 7.041 .276 & $X_{25}$ & 566.916 & 566.997 \\
\hline$X_{8}$ & 7.041 .832 & 7.041 .330 & $X_{26}$ & 570.072 & 570.151 \\
\hline$X_{9}$ & 7.039 .786 & 7.039 .286 & $X_{27}$ & 883.514 & 883.452 \\
\hline$X_{10}$ & 7.042 .385 & 7.041 .883 & $X_{28}$ & 885.058 & 884.995 \\
\hline$X_{11}$ & 7.043 .659 & 7.043 .158 & $X_{29}$ & 886.067 & 886.003 \\
\hline$X_{12}$ & 7.042 .365 & 7.041 .866 & $x_{30}$ & 885.984 & 885.921 \\
\hline$X_{13}$ & 3.403 .545 & 3.403 .750 & $x_{31}$ & 885.966 & 885.903 \\
\hline$X_{14}$ & 3.402 .737 & 3.402 .938 & $x_{32}$ & 885.516 & 885.453 \\
\hline$X_{15}$ & 3.401 .618 & 3.401 .819 & $X_{33}$ & 887.371 & 887.314 \\
\hline$X_{16}$ & 3.401 .389 & 3.401 .590 & $X_{34}$ & 885.636 & 885.572 \\
\hline$X_{17}$ & 3.402 .919 & 3.403 .119 & & & \\
\hline
\end{tabular}

Observando os valores dos coeficientes da função discriminante, mostrados na Tabela 50, das variáveis de relevo, a clinografia $\left(X_{2}\right)$ apresentou o maior peso; quanto às variáveis de precipitação, aquela referente à média do trimestre mais chuvoso $\left(\mathrm{X}_{4}\right)$ apresentou o maior peso. De forma geral, as 
variáveis pedológicas foram as que obtiveram os maiores coeficientes, seguidas das litológicas, das de cobertura vegetal e das morfológicas.

Através da função discriminante calculou-se o valor de $Z$ discriminante para cada área amostrada dos dois grupos, e com base nesse valor foram calculadas as probabilidades posteriores de cada área pertencer a cada um dos dois grupos.

Dessa forma, a função discriminante foi aplicada sobre a amostra de análise, reclassificando cada área entre os dois grupos, com base no cálculo da probabilidade posterior. Os resultados da reclassificação são mostrados na Tabela 51, onde aparecem o número e a taxa de áreas corretamente reclassificadas por grupo e no geral.

Tabela 51. Número e taxa de áreas corretamente reclassificadas por grupo e no geral pela função discriminante.

\begin{tabular}{lccl}
\hline Grupo & $\begin{array}{c}\text { Áreas com } \\
\text { Escorregamento }\end{array}$ & $\begin{array}{c}\text { Áreas sem } \\
\text { Escorregamento }\end{array}$ & Total \\
\hline Áreas com Escorregamentos & 273 & 52 & 325 \\
& $84,00 \%$ & $16,00 \%$ & $100,00 \%$ \\
\hline Áreas sem Escorregamentos & 100 & 224 & 324 \\
& $30,86 \%$ & $69,14 \%$ & $100,00 \%$ \\
\hline
\end{tabular}

A Tabela 51 mostra que para o grupo de áreas com escorregamento, $84,00 \%$ das áreas foram corretamente classificadas, e no grupo de áreas sem escorregamento, $69,14 \%$ das áreas foram corretamente classificadas.

Na Tabela 52 temos um resumo da taxa de erro da classificação da função discriminante por grupo e no geral. 
Tabela 52. Taxa de erro da classificação da pela função discriminante por grupo e no geral.

\begin{tabular}{lccr}
\hline & $\begin{array}{c}\text { Áreas com } \\
\text { Escorregamento }\end{array}$ & $\begin{array}{c}\text { Áreas sem } \\
\text { Escorregamento }\end{array}$ & Total \\
\hline Taxa de Erro & $16 \%$ & $30,86 \%$ & $23,43 \%$ \\
\hline Taxa Prévia & $50 \%$ & $50 \%$ & \\
\hline
\end{tabular}

Dos resultados da Tabela 52, ressalta-se a taxa total de erro de $23,43 \%$, significando, por conseqüência, uma taxa de acerto de $76,57 \%$.

\subsection{Validação da função discriminante}

Para avaliação da função discriminante, esta foi aplicada sobre a amostra de validação, composta de áreas que não foram amostradas para sua construção.

O número e a taxa das áreas corretamente classificadas pela função discriminante nos dois grupos é mostrada na Tabela 53.

Tabela 53. Número e taxa de áreas corretamente classificadas por grupo e no geral pela função discriminante.

\begin{tabular}{lccl}
\hline Grupo & $\begin{array}{c}\text { Áreas com } \\
\text { Escorregamento }\end{array}$ & $\begin{array}{c}\text { Áreas sem } \\
\text { Escorregamento }\end{array}$ & \multicolumn{1}{c}{ Total } \\
\hline Áreas com Escorregamento & 89 & 19 & 108 \\
& $82,41 \%$ & $17,59 \%$ & $100,00 \%$ \\
\hline Áreas sem Escorregamento & 32 & 76 & 108 \\
& $29,63 \%$ & $70,37 \%$ & $100,00 \%$ \\
\hline
\end{tabular}


A Tabela 53 mostra que para o grupo de áreas com escorregamento, $82,41 \%$ das áreas foram corretamente classificadas e no grupo de áreas sem escorregamento, $70,37 \%$ das áreas foram corretamente classificadas.

Na Tabela 54 temos um resumo da taxa de erro da classificação da função discriminante por grupo e no geral.

Tabela 54. Taxa de erro da classificação da pela função discriminante por grupo e no geral.

\begin{tabular}{lccc}
\hline & $\begin{array}{c}\text { Áreas com } \\
\text { Escorregamento }\end{array}$ & $\begin{array}{c}\text { Áreas sem } \\
\text { Escorregamento }\end{array}$ & Total \\
\hline Taxa de Erro & 17,59 & $29,63 \%$ & $23,61 \%$ \\
\hline Taxa Prévia & $50 \%$ & $50 \%$ & \\
\hline
\end{tabular}

Dos resultados da Tabela 54, ressalta-se a taxa total de erro de $23,61 \%$, significando, por conseqüência, uma taxa de acerto de $76,39 \%$.

\subsection{Mapa de risco de escorregamento}

A função discriminante foi aplicada sobre cada unidade de terreno da área de estudo, obtendo-se como resultado a probabilidades posteriores de cada uma pertencer ao grupo de áreas com escorregamento e ao grupo de áreas sem escorregamento. Considerou-se a probabilidade de pertencerem ao grupo de áreas com escorregamento como sendo o risco de escorregamento das mesmas. Esses valores de risco de escorregamento variaram entre 0 (zero) e 1 (um). Agrupando-se esses valores em classes de risco de escorregamento, gerou-se um mapa de risco de escorregamento (ANEXO L) da 
área de estudo. A distribuição da superfície desse mapa em função dessas classes, é mostrada na Tabela 55.

Tabela 55. Distribuição da superfície do mapa de risco de escorregamento da área de estudo em função de suas classes.

\begin{tabular}{|l|r|r|}
\hline \multicolumn{1}{|c|}{$\begin{array}{c}\text { Classe de Risco de } \\
\text { Escorregamento }\end{array}$} & \multicolumn{1}{|c|}{ Área $\left(\mathrm{m}^{2}\right)$} & \multicolumn{1}{c|}{$(\%)$} \\
\hline muito baixo $(0,0-0,2)$ & $47.590 .677,9$ & 44,4 \\
\hline baixo $(0,2-0,4)$ & $10.880 .415,0$ & 10,2 \\
\hline médio $(0,4-0,6)$ & $9.905 .686,8$ & 9,3 \\
\hline alto $(0,6-0,8)$ & $13.773 .098,8$ & 12,9 \\
\hline muito alto $(0,8-1)$ & $13.630 .894,7$ & 12,7 \\
\hline área não classificada (1) & $11.289 .026,9$ & 10,5 \\
\hline total & $107.069 .800,0$ & 100,0 \\
\hline
\end{tabular}

Os dados da Tabela 55 mostram que $25,6 \%$ da área de estudo foi classificada com risco de escorregamento alto e muito alto, e houve predominância de áreas com risco de escorregamento muito baixo $(44,4 \%)$. áreas não classificadas, mostradas nessa tabela, representaram regiões onde ocorreram uma ou mais das 11 variáveis não consideradas na função discriminante. Nesses casos, a função discriminante resultou em um valor de $Z$ discriminante, que muito diferiu dos valores médios de $Z$ discriminante para os grupos de áreas com escorregamento e de áreas sem escorregamento, conforme é mostrado na Tabela 56.

Tabela 56. Valores de $Z$ máximo, mínimo e médio para áreas com escorregamento, sem escorregamento e não classificadas.

\begin{tabular}{|l|l|l|l|}
\hline & $Z$ máximo & $Z$ mínimo & $Z$ médio \\
\hline Áreas com Escorregamento & 5.950 .930 & 5.943 .840 & 5.949 .122 \\
\hline Áreas sem Escorregamento & 5.950 .951 & 5.945 .459 & 5.948 .831 \\
\hline Áreas não Classificadas & 5.385 .130 & 1.093 .139 & 3.231 .963 \\
\hline
\end{tabular}


O cálculo das probabilidades posteriores, levou em consideração a posição dos valores de $Z$ discriminantes das amostras de áreas com e sem escorregamento em relação ao valor de $Z$ médio de cada grupo. Como se observa na Tabela 56, no caso das áreas não classificadas os valores calculados de $Z$ ficaram muito distantes dos valores de $Z$ médio de cada grupo, fazendo com que fosse atribuído a essas áreas o valor de probabilidade 1 , ou seja, $100 \%$ de probabilidade de risco de escorregamento, que não é real, mas sim fruto do uso não apropriado da função discriminante, que não deve ser aplicada em amostras que não tenham correspondência a todas suas variáveis.

Através de uma análise visual no mapa de risco de escorregamento percebe-se que as áreas de risco de escorregamento muito baixo ocorreram predominantemente na baixa encosta, áreas de risco de escorregamento baixo e médio ocorreram mais na baixa e média encosta. Áreas com risco de escorregamento alto e muito alto ocorreram predominantemente da média e alta encosta, concentradas nas encostas da margem direita do rio Mogi. Áreas não classificadas ocorreram na sua maior parte na baixa encosta ao longo dos canais fluviais.

Para uma melhor caracterização das classes de risco de escorregamento sobrepôs-se o mapa de risco de escorregamento a cada um dos mapas dos fatores de instabilidade utilizados, calculando-se a taxa de coincidência entre as classes dos mesmos. Essa operação realizou-se utilizando-se ferramentas de geoprocessamento do ArcView Spatial Analyst.

Coincidindo o mapa de risco de escorregamentos com o mapa hipsométrico, obteve-se as taxas de coincidência resultantes da sobreposição das classes que compõem cada mapa, conforme a Tabela 57. 
Tabela 57. Coincidência das classes de risco de escorregamento com as classes hipsométricas.

\begin{tabular}{|l|c|c|c|c|c|c|c|}
\hline & \multicolumn{7}{|c|}{ Classes Hipsométricas (\%) } \\
\hline \multicolumn{1}{|c|}{ Risco } & $0-100 \mathrm{~m}$ & $\begin{array}{l}100- \\
300 \mathrm{~m}\end{array}$ & $\begin{array}{l}300- \\
500 \mathrm{~m}\end{array}$ & $\begin{array}{l}500- \\
700 \mathrm{~m}\end{array}$ & $\begin{array}{l}700- \\
900 \mathrm{~m}\end{array}$ & $\begin{array}{l}900- \\
1.000 \mathrm{~m}\end{array}$ & total \\
\hline muito baixo & 57,6 & 24,8 & 7,3 & 5,0 & 5,0 & 0,5 & 100,0 \\
\hline baixo & 8,9 & 47,1 & 23,2 & 15,8 & 4,6 & 0,4 & 100,0 \\
\hline médio & 3,6 & 41,2 & 29,4 & 17,3 & 8,3 & 0,2 & 100,0 \\
\hline alto & 0,2 & 27,1 & 38,5 & 25,5 & 8,4 & 0,3 & 100,0 \\
\hline muito alto & 0,1 & 8,9 & 29,2 & 38,8 & 22,2 & 0,8 & 100,0 \\
\hline não classificado & 95,6 & 2,3 & 0,2 & 0,0 & 1,8 & 0,1 & 100,0 \\
\hline
\end{tabular}

Conforme a Tabela 57, a classe de risco de escorregamento muito baixo ocorreu com maior freqüência entre $0 \mathrm{~m}$ e $100 \mathrm{~m}$ de altitude $(57,6 \%)$; as classes de risco de escorregamento baixo e médio ocorreram com maior freqüência entre $100 \mathrm{~m}$ e $300 \mathrm{~m}$ de altitude (47,1\% e 41,2\%, respectivamente); a classe de risco de escorregamento alto ocorreu com maior freqüência entre $300 \mathrm{~m}$ e $500 \mathrm{~m}$ de altitude (38,5\%); a classe de risco de escorregamento muito alto ocorreu com maior freqüência entre $500 \mathrm{~m}$ e $700 \mathrm{~m}$ de altitude $(38,8 \%)$; as áreas de risco não classificado ocorreram com maior freqüência entre $0 \mathrm{~m} \mathrm{e}$ $100 \mathrm{~m}$ de altitude $(95,6 \%)$.

Coincidindo o mapa de risco de escorregamentos com o mapa clinográfico, obteve-se as taxas de coincidência resultantes da sobreposição das classes que compõem cada mapa, conforme a Tabela 58. 
Tabela 58. Coincidência das classes de risco de escorregamento com as classes clinográficas.

\begin{tabular}{|l|c|c|cc|cc|c|l|l|}
\hline & \multicolumn{7}{|c|}{ Classes Clinográficas (\%) } \\
\hline Risco & $0^{\circ}-7^{\circ}$ & $7^{\circ}-17^{\circ}$ & $\begin{array}{l}17^{\circ} \\
26^{\circ}\end{array}$ & $\begin{array}{l}26^{\circ} \\
36^{\circ}\end{array}$ & $\begin{array}{l}36^{\circ} \\
45^{\circ}\end{array}$ & $>45^{\circ}$ & total \\
\hline muito baixo & 39,2 & 22,6 & 24,6 & 12,4 & 1,2 & 0,0 & 100,0 \\
\hline baixo & 5,4 & 21,8 & 39,4 & 29,3 & 4,1 & 0,0 & 100,0 \\
\hline médio & 5,1 & 21,0 & 37,5 & 31,0 & 5,4 & 0,1 & 100,0 \\
\hline alto & 2,5 & 11,9 & 34,5 & 43,8 & 7,2 & 0,2 & 100,0 \\
\hline muito alto & 1,7 & 5,5 & 22,7 & 54,0 & 15,3 & 0,8 & 100,0 \\
\hline não classificado & 80,1 & 12,1 & 6,2 & 1,6 & 0,0 & 0,0 & 100,0 \\
\hline
\end{tabular}

Conforme a Tabela 58, a classe de risco de escorregamento muito baixo ocorreu com maior freqüência entre $0^{\circ}$ e $7^{\circ}(39,2 \%)$; as classes de risco de escorregamento baixo e médio ocorreram com maior freqüência entre $17^{\circ} \mathrm{e}$ $26^{\circ}$ (39,4\% e $37,5 \%$, respectivamente); as classes de risco de escorregamento alto e muito alto ocorreram com maior freqüência entre $26^{\circ}$ e $36^{\circ}(43,8 \%$ e $54,0 \%$, respectivamente); as áreas de risco não classificado ocorreram com maior freqüência entre $0^{\circ}$ e $7^{\circ}(80,1 \%)$.

Coincidindo o mapa de risco de escorregamentos com o mapa de exposição de vertentes, obteve-se as taxas de coincidência resultantes da sobreposição das classes que compõem cada mapa, conforme a Tabela 59. 
Tabela 59. Coincidência das classes de risco de escorregamento com as classes de exposição de vertentes.

\begin{tabular}{|l|l|l|r|r|r|r|r|r|r|r|}
\hline & \multicolumn{10}{|c|}{ Classes de Exposição de Vertentes (\%) } \\
\hline \multicolumn{1}{|c|}{ Risco } & N & NE & L & SE & S & SO & O & NO & $\begin{array}{l}\text { PLA- } \\
\text { NO }\end{array}$ & total \\
\hline muito baixo & 7,8 & 4,7 & 9,6 & 18,9 & 15,1 & 7,2 & 11,6 & 14,8 & 10,3 & 100,0 \\
\hline baixo & 5,8 & 2,5 & 8,1 & 17,3 & 15,9 & 7,6 & 17,3 & 25,5 & 0,0 & 100,0 \\
\hline médio & 3,9 & 4,1 & 10,0 & 21,3 & 21,6 & 10,9 & 13,5 & 14,4 & 0,2 & 100,0 \\
\hline alto & 2,2 & 5,0 & 16,6 & 28,1 & 29,5 & 11,2 & 4,4 & 3,1 & 0,0 & 100,0 \\
\hline muito alto & 2,7 & 7,4 & 25,0 & 32,3 & 20,5 & 7,7 & 3,3 & 0,9 & 0,0 & 100,0 \\
\hline não & 9,0 & 4,9 & 9,1 & 16,7 & 12,3 & 5,2 & 5,5 & 5,2 & 32,3 & 100,0 \\
classificado & & & & & & & & & & \\
\hline
\end{tabular}

Conforme a Tabela 59, a classe de risco de escorregamento muito baixo ocorreu com maior freqüência em vertentes de exposição $S(15,1 \%)$ e NO $(14,8 \%)$; a classe de risco de escorregamento baixo ocorreu com maior freqüência em vertentes de exposição NO $(25,5 \%)$; as classes de risco de escorregamento médio e alto ocorreram com maior freqüência em vertentes de exposição SE $(21,3 \%$ e $28,1 \%$, respectivamente) e $S(21,6 \%$ e $29,5 \%$, respectivamente); as classes de risco de escorregamento muito alto ocorreram com maior freqüência em vertentes de exposição L $(25,0 \%)$ e SE $(32,3 \%)$; as áreas de risco não classificado ocorreram com maior freqüência em áreas planas $(32,3 \%)$.

Coincidindo o mapa de risco de escorregamentos com o mapa pedológico, obteve-se as taxas de coincidência resultantes da sobreposição das classes que compõem cada mapa, conforme a Tabela 60 . 
Tabela 60. Coincidência das classes de risco de escorregamento com as classes pedológicas.

\begin{tabular}{|c|c|c|c|c|c|c|c|c|c|}
\hline & \multicolumn{9}{|c|}{ Classes Pedológicas (\%) } \\
\hline Risco & $L V a_{1}$ & $\mathrm{LVa}_{3}$ & $\mathrm{Ca}_{1}$ & $\mathrm{Ca}_{2}$ & $\mathrm{Ca}_{3}$ & $A$ & SM & $\begin{array}{l}\text { OUTR } \\
\text { OS_S }\end{array}$ & total \\
\hline muito baixo & 16,0 & 44,3 & 0,7 & 4,3 & 0,1 & 12,0 & 2,2 & 20,5 & 100,0 \\
\hline baixo & 51,4 & 36,3 & 4,9 & 5,7 & 1,5 & 0,1 & 0,0 & 0,1 & 100,0 \\
\hline médio & 55,6 & 33,2 & 4,8 & 2,5 & 4,0 & 0,0 & 0,0 & 0,0 & 100,0 \\
\hline alto & 56,6 & 36,1 & 0,7 & 0,2 & 6,3 & 0,0 & 0,0 & 0,0 & 100,0 \\
\hline muito alto & 62,5 & 27,4 & 0,0 & 0,0 & 10,0 & 0,1 & 0,0 & 0,0 & 100,0 \\
\hline não classificado & 8,3 & 14,8 & 0,0 & 1,2 & 0,0 & 53,7 & 0,0 & 22,0 & 100,0 \\
\hline
\end{tabular}

Conforme a Tabela 60, a classe de risco de escorregamento muito baixo ocorreu com maior freqüência em latossolo vermelho-amarelo $\left(\mathrm{LVa}_{3}\right)$ $(44,3 \%)$; as classes de risco de escorregamento baixo, médio, alto e muito alto ocorreram com maior freqüência latossolo vermelho-amarelo $\left(\operatorname{LVa}_{1}\right)(51,4 \%$, $55,6 \%, 56,6 \%$ e $62,5 \%$, respectivamente); as áreas de risco não classificado ocorreram com maior freqüência em solo aluvial (A) $(53,7 \%)$.

Coincidindo o mapa de risco de escorregamentos com o mapa de cobertura vegetal, obteve-se as taxas de coincidência resultantes da sobreposição das classes que compõem cada mapa, conforme a Tabela 61. 
Tabela 61. Coincidência das classes de risco de escorregamento com as classes de cobertura vegetal.

\begin{tabular}{|l|l|l|l|l|l|l|l|l|l|l|}
\hline & \multicolumn{10}{|c|}{ Classes de Cobertura Vegetal (\%) } \\
\hline \multicolumn{1}{|c|}{ Risco } & Aa & Am & Ab & A/A & H & Mg & E & SN & $\begin{array}{l}\text { OUTR } \\
\text { OS_V }\end{array}$ & total \\
\hline muito baixo & 5,4 & 19,6 & 20,9 & 5,2 & 26,6 & 1,7 & 1,1 & 1,5 & 18,2 & 100,0 \\
\hline baixo & 0,7 & 32,3 & 39,1 & 7,0 & 18,1 & 0,0 & 0,0 & 0,0 & 2,8 & 100,0 \\
\hline médio & 0,0 & 30,8 & 52,6 & 7,6 & 8,0 & 0,0 & 0,0 & 0,0 & 1,0 & 100,0 \\
\hline alto & 0,0 & 10,2 & 68,8 & 16,0 & 2,7 & 0,0 & 0,0 & 0,0 & 2,2 & 100,0 \\
\hline muito alto & 0,0 & 3,8 & 67,3 & 21,9 & 0,4 & 0,1 & 0,0 & 0,0 & 6,6 & 100,0 \\
\hline $\begin{array}{l}\text { não } \\
\text { classificado }\end{array}$ & 0,0 & 7,6 & 13,5 & 3,3 & 56,3 & 0,1 & 2,4 & 1,6 & 15,1 & 100,0 \\
\hline
\end{tabular}

Conforme a Tabela 61, a classe de risco de escorregamento muito baixo ocorreu com maior freqüência em áreas com cobertura vegetal do tipo herbáceo a arbustivo $(H)(26,6 \%)$; as classes de risco de escorregamento baixo, médio, alto e muito alto ocorreram com maior freqüência em áreas com cobertura vegetal do tipo arbóreo baixo $(\mathrm{Ab})(39,1 \%, 52,6 \%, 68,8 \%$ e $67,3 \%$, respectivamente); as áreas de risco não classificado ocorreram com maior freqüência em áreas com cobertura vegetal do tipo herbáceo a arbustivo $(H)$ $(56,3 \%)$.

Coincidindo o mapa de risco de escorregamentos com o mapa morfológico, obteve-se as taxas de coincidência resultantes da sobreposição das classes que compõem cada mapa, conforme a Tabela 62. 
Tabela 62 . Coincidência das classes de risco de escorregamento com as classes morfológicas.

\begin{tabular}{|l|c|l|l|l|l|l|l|l|}
\hline & \multicolumn{7}{|c|}{ Classes Morfológicas (\%) } \\
\hline \multicolumn{1}{|c|}{ Risco } & VCX & VR & VCC & PF & RC & AT & $\begin{array}{l}\text { OUTR } \\
\text { OS_M }\end{array}$ & total \\
\hline muito baixo & 7,3 & 50,9 & 0,0 & 0,6 & 7,4 & 16,8 & 17,0 & 100,0 \\
\hline baixo & 14,9 & 84,1 & 0,0 & 0,0 & 0,0 & 0,5 & 0,5 & 100,0 \\
\hline médio & 14,2 & 85,8 & 0,0 & 0,0 & 0,0 & 0,0 & 0,0 & 100,0 \\
\hline alto & 9,3 & 90,7 & 0,0 & 0,0 & 0,0 & 0,0 & 0,0 & 100,0 \\
\hline muito alto & 18,8 & 81,1 & 0,0 & 0,1 & 0,0 & 0,0 & 0,0 & 100,0 \\
\hline não classificado & 3,2 & 14,7 & 0,0 & 61,9 & 3,5 & 11,3 & 4,7 & 100,0 \\
\hline
\end{tabular}

Conforme a Tabela 62, as classes de risco de escorregamento muito baixo, baixo, médio, alto e muito alto ocorreram com maior freqüência em vertentes retilíneas (VR) $(50,9 \%, 84,1 \%, 85,8 \%, 90,7 \%$ e $81,1 \%$, respectivamente); as áreas de risco não classificado ocorreram com maior freqüência em planicies fluviais (PF) $(61,9 \%)$.

Coincidindo o mapa de risco de escorregamentos com o mapa litológico, obteve-se as taxas de coincidência resultantes da sobreposição das classes que compõem cada mapa, conforme a Tabela 63. 
Tabela 63. Coincidência das classes de risco de escorregamento com as classes litológicas.

\begin{tabular}{|l|c|c|c|c|c|c|c|c|c|c|l|l|l|}
\hline & \multicolumn{10}{|c|}{ Classes Litológicas (\%) } \\
\hline Risco & Qc & Qb & $\begin{array}{l}\text { PSE } \\
\text { OYt }\end{array}$ & $\begin{array}{l}\text { PSE } \\
\text { OYm }\end{array}$ & PSpF & PSpX & $\begin{array}{l}\text { Pse } \\
\text { Mc }\end{array}$ & AcMn & AcMp & AcMg & PSpC & OuTROS_L & total \\
\hline muito baixo & 0,7 & 0,0 & 3,7 & 2,6 & 0,8 & 33,0 & 0,4 & 14,5 & 6,8 & 0,0 & 1,6 & 36,0 & 100,0 \\
\hline baixo & 3,3 & 0,0 & 0,3 & 14,0 & 1,2 & 33,7 & 0,0 & 28,5 & 17,2 & 0,0 & 0,5 & 1,2 & 100,0 \\
\hline médio & 9,2 & 0,0 & 0,0 & 4,5 & 0,0 & 39,4 & 0,0 & 32,3 & 14,0 & 0,0 & 0,5 & 0,1 & 100,0 \\
\hline alto & 9,6 & 0,0 & 0,0 & 0,0 & 0,0 & 40,6 & 0,0 & 46,4 & 2,9 & 0,0 & 0,0 & 0,0 & 100,0 \\
\hline muito alto & 17,8 & 0,0 & 0,0 & 0,0 & 0,0 & 21,1 & 0,0 & 61,9 & 0,0 & 0,0 & 0,0 & 0,1 & 100,0 \\
\hline não classificado & 0,3 & 19,7 & 0,0 & 0,0 & 0,0 & 11,3 & 43,5 & 0,1 & 10,9 & 0,3 & 0,0 & 14,0 & 100,0 \\
\hline
\end{tabular}

Conforme a Tabela 63, a classe de risco de escorregamento muito baixo ocorreu com maior freqüência em áreas em áreas urbano-industriais $(36,0 \%)$ e em áreas de litologia do tipo micaxistos (PSpX) $(33,0 \%)$; as classes de risco de escorregamento baixo, médio e alto ocorreram com maior freqüência em áreas de litologia do tipo micaxistos (PSpX) $(33,7 \%$ e $39,4 \%$, respectivamente) e migmatitos estromatíticos (AcMn) $(28,5 \%, 32,3 \%$, respectivamente); as classes de risco de escorregamento alto e muito alto ocorreu com maior freqüência em áreas de litologia do tipo, migmatitos estromatíticos (AcMn) (46,4\% e 61,1\%, respectivamente) micaxistos (PSpX) $(40,6 \%$ e $21,1 \%$, respectivamente); as áreas de risco não classificado ocorreram com maior freqüência em áreas de litologia do tipo migmatitos estromatiticos (PseMc) $(43,5 \%)$.

Coincidindo o mapa de risco de escorregamentos com o mapa de precipitação média do trimestre mais chuvoso, obteve-se as taxas de coincidência resultantes da sobreposição das classes que compõem cada mapa, conforme a Tabela 64. 
Tabela 64. Coincidência das classes de risco de escorregamento com as classes de precipitação média do trimestre mais chuvoso.

\begin{tabular}{|l|l|l|l|l|l|l|}
\hline \multirow{2}{*}{ Risco } & \multicolumn{5}{|c|}{ Classes de Precipitação Média do Trimestre mais Chuvoso } \\
\hline \multirow{2}{*}{$\begin{array}{l}800- \\
900 \mathrm{~mm}\end{array}$} & $\begin{array}{l}900- \\
1.000 \mathrm{~mm}\end{array}$ & $\begin{array}{l}1.000- \\
1.100 \mathrm{~mm}\end{array}$ & $\begin{array}{l}1.100- \\
1.200 \mathrm{~mm}\end{array}$ & $\begin{array}{l}1.200- \\
1300 \mathrm{~mm}\end{array}$ & total \\
\hline muito baixo & 0,0 & 24,8 & 66,8 & 8,1 & 0,2 & 100,0 \\
\hline baixo & 0,0 & 9,1 & 58,9 & 27,8 & 4,2 & 100,0 \\
\hline médio & 0,0 & 2,6 & 52,5 & 34,6 & 10,3 & 100,0 \\
\hline alto & 0,0 & 0,8 & 34,7 & 41,1 & 23,4 & 100,0 \\
\hline muito alto & 0,0 & 0,4 & 29,8 & 48,0 & 21,8 & 100,0 \\
\hline não classificado & 0,0 & 33,1 & 1,8 & 1,8 & 0,1 & 100,0 \\
\hline
\end{tabular}

Conforme a Tabela 64 , as classes de risco de escorregamento muito baixo ocorreram com maior freqüência entre $1.000 \mathrm{~mm}$ e $1.100 \mathrm{~mm}$ de precipitação média do trimestre mais chuvoso $(66,8 \%, 58,9 \%$ e $52,5 \%$, respectivamente); as classes de risco de escorregamento alto e muito alto ocorreram com maior freqüência entre $1.100 \mathrm{~mm}$ e $1.200 \mathrm{~mm}$ de precipitação média do trimestre mais chuvoso $(41,1 \%$ e $48,0 \%$, respectivamente); as áreas de risco não classificado ocorreram com maior freqüência entre $900 \mathrm{~mm}$ e 1.000 de precipitação média do trimestre mais chuvoso $(33,1 \%)$.

Coincidindo o mapa de risco de escorregamentos com o mapa de precipitação média total anual, obteve-se as taxas de coincidência resultantes da sobreposição das classes que compõem cada mapa, conforme a Tabela 65. 
Tabela 65. Coincidência das classes de risco de escorregamento com as classes de precipitação média total anual.

\begin{tabular}{|c|c|c|c|c|c|c|c|c|c|c|}
\hline & \multicolumn{10}{|c|}{ Classes de Precipitação Média Total Anual (\%) } \\
\hline Risco & $\begin{array}{c}2.200 \\
\mathrm{~mm} \\
- \\
2.300 \\
\mathrm{~mm}\end{array}$ & $\begin{array}{c}2.300 \\
\mathrm{~mm} \\
- \\
2.400 \\
\mathrm{~mm}\end{array}$ & $\begin{array}{c}2.400 \\
\mathrm{~mm} \\
- \\
2.500 \\
\mathrm{~mm}\end{array}$ & $\begin{array}{c}2.500 \\
\mathrm{~mm} \\
- \\
2.600 \\
\mathrm{~mm}\end{array}$ & $\begin{array}{c}2.600 \\
\mathrm{~mm} \\
- \\
2.700 \\
\mathrm{~mm}\end{array}$ & $\begin{array}{c}2.700 \\
\mathrm{~mm} \\
- \\
2.800 \\
\mathrm{~mm}\end{array}$ & $\begin{array}{c}2.800 \\
\mathrm{~mm} \\
- \\
2.900 \\
\mathrm{~mm}\end{array}$ & $\begin{array}{c}2.900 \\
\mathrm{~mm} \\
- \\
3.000 \\
\mathrm{~mm}\end{array}$ & $\begin{array}{c}3.000 \\
\mathrm{~mm} \\
- \\
3.100 \\
\mathrm{~mm}\end{array}$ & $\begin{array}{c}3.100 \\
\mathrm{~mm} \\
- \\
3.200 \\
\mathrm{~mm}\end{array}$ \\
\hline muito baixo & 0,0 & 0,0 & 0,0 & 2,7 & 15,7 & 10,5 & 13,1 & 15,4 & 23,7 & 10,2 \\
\hline baixo & 0,0 & 0,0 & 0,0 & 0,1 & 1,1 & 6,4 & 7,8 & 10,2 & 20,6 & 14,4 \\
\hline médio & 0,0 & 0,0 & 0,0 & 0,0 & 0,2 & 1,6 & 3,0 & 4,3 & 13,8 & 15,5 \\
\hline alto & 0,0 & 0,0 & 0,0 & 0,0 & 0,0 & 0,4 & 0,8 & 3,0 & 9,9 & 10,2 \\
\hline muito alto & 0,0 & 0,0 & 0,0 & 0,0 & 0,1 & 0,0 & 0,5 & 5,8 & 11,4 & 8,9 \\
\hline $\begin{array}{l}\text { não } \\
\text { classificado }\end{array}$ & 0,0 & 0,0 & 0,0 & 0,1 & 16,4 & 26,3 & 17,5 & 16,7 & 18,8 & 2,3 \\
\hline & \multicolumn{10}{|c|}{ Classes de Precipitação Média Total Anual (\%) } \\
\hline Risco & $\begin{array}{c}3.200 \\
\mathrm{~mm} \\
- \\
3.300 \\
\mathrm{~mm}\end{array}$ & $\begin{array}{c}3.300 \\
\mathrm{~mm} \\
- \\
3.400 \\
\mathrm{~mm}\end{array}$ & $\begin{array}{c}.400 \\
\mathrm{~mm} \\
- \\
3.500 \\
\mathrm{~mm}\end{array}$ & $\begin{array}{c}3.500 \\
\mathrm{~mm} \\
- \\
3.600 \\
\mathrm{~mm}\end{array}$ & $\begin{array}{c}3.600 \\
\mathrm{~mm} \\
- \\
3.700 \\
\mathrm{~mm}\end{array}$ & $\begin{array}{c}3.700 \\
\mathrm{~mm} \\
- \\
3.800 \\
\mathrm{~mm}\end{array}$ & $\begin{array}{c}3.800 \\
\mathrm{~mm} \\
- \\
3.900 \\
\mathrm{~mm}\end{array}$ & $\begin{array}{c}3.900 \\
\mathrm{~mm} \\
- \\
4.000 \\
\mathrm{~mm}\end{array}$ & \multicolumn{2}{|c|}{ total } \\
\hline muito baixo & 4,1 & 2,1 & 1,2 & 0,7 & 0,5 & 0,1 & 0,0 & 0,0 & \multicolumn{2}{|l|}{100,0} \\
\hline baixo & 11,9 & 8,8 & 7,3 & 3,4 & 4,7 & 3,1 & 0,2 & 0,0 & \multicolumn{2}{|l|}{100,0} \\
\hline médio & 18,4 & 14,2 & 10,4 & 5,0 & 5,9 & 6,0 & 1,7 & 0,0 & \multicolumn{2}{|l|}{100,0} \\
\hline alto & 17,7 & 11,8 & 8,7 & 8,6 & 7,9 & 10,2 & 9,9 & 0,8 & \multicolumn{2}{|l|}{100,0} \\
\hline muito alto & 10,6 & 9,5 & 7,0 & 12,7 & 10,7 & 6,0 & 7,4 & 9,4 & \multicolumn{2}{|c|}{100,0} \\
\hline $\begin{array}{l}\text { não } \\
\text { classificado }\end{array}$ & 0,7 & 0,2 & 0,2 & 0,2 & 0,4 & 0,2 & 0,0 & 0,0 & \multicolumn{2}{|c|}{100,0} \\
\hline
\end{tabular}

Conforme a Tabela 65, as classes de risco de escorregamento muito baixo e baixo ocorreram com maior freqüência entre $3.000 \mathrm{~mm}$ e 3.100 $\mathrm{mm}$ de precipitação média total anual $(23,7 \%$ e $20,6 \%$, respectivamente); as 
classes de risco de escorregamento médio e alto ocorreram com maior freqüência entre $3.200 \mathrm{~mm}$ e $3.300 \mathrm{~mm}$ de precipitação média total anual (18,4\% e $17,7 \%$, respectivamente); a classe de risco de escorregamento muito alto ocorreu com maior freqüência entre $3.500 \mathrm{~mm}$ e $3.600 \mathrm{~mm}$ de precipitação média total anual (12,7\%); as áreas de risco não classificado ocorreram com maior freqüência entre $2.700 \mathrm{~mm}$ e $2.800 \mathrm{~mm}$ de precipitação média total anual $(26,3 \%)$.

Comparando os fatores de instabilidade predominantes nas áreas classificadas com os dois riscos de escorregamento extremos, muito baixo e muito alto, com os fatores de instabilidade predominantes na área de estudo, áreas com escorregamento e área sem escorregamento, obteve-se a Tabela 66.

Tabela 66. Fatores de instabilidade predominantes nas áreas classificadas com risco de escorregamento muito baixo e muito alto, na área de estudo, nas áreas com escorregamento e nas áreas sem escorregamento.

\begin{tabular}{|c|c|c|c|c|c|}
\hline & & & & Risco de Es & orregamento \\
\hline $\begin{array}{l}\text { Fatores de } \\
\text { Instabilidade }\end{array}$ & $\begin{array}{l}\text { Área de } \\
\text { Estudo }\end{array}$ & $\begin{array}{c}\text { Áreas com } \\
\text { Escorrega- } \\
\text { mento }\end{array}$ & $\begin{array}{c}\text { Áreas sem } \\
\text { Escorrega- } \\
\text { mento }\end{array}$ & Muito Baixo & Muito Alto \\
\hline hipsometria & $0 m-300 m$ & $300 m-700 m$ & $100 m-300 m$ & $0 m-100 m$ & $500 m-700 m$ \\
\hline clinografia & $\begin{array}{l}0^{0}-7^{\circ} \\
17^{\circ}-26^{\circ}\end{array}$ & $26^{\circ}-36^{\circ}$ & $17^{\circ}-26^{\circ}$ & $0^{\circ}-7^{\circ}$ & $26^{\circ}-36^{\circ}$ \\
\hline $\begin{array}{l}\text { exposição de } \\
\text { vertentes }\end{array}$ & $\begin{array}{l}S E \\
S\end{array}$ & & $\begin{array}{l}\text { SE } \\
S\end{array}$ & $\begin{array}{l}\text { SE } \\
S\end{array}$ & $\begin{array}{l}S E \\
L\end{array}$ \\
\hline pedologia & $\begin{array}{l}\mathrm{LVa}_{1} \\
L \mathrm{LV}_{3}\end{array}$ & $\mathrm{LVa}_{1}$ & $L V a_{1}$ & $\mathrm{LVa}_{3}$ & $L \mathrm{La}_{1}$ \\
\hline $\begin{array}{l}\text { cobertura } \\
\text { vegetal }\end{array}$ & $\begin{array}{l}A b \\
H\end{array}$ & $A b$ & $A b$ & $H$ & $A b$ \\
\hline morfologia & VR & VR & VR & VR & VR \\
\hline
\end{tabular}


Tabela 66. Fatores de instabilidade predominantes nas áreas classificadas com risco de escorregamento muito baixo e muito alto, na área de estudo, nas áreas com escorregamento e nas áreas sem escorregamento.

\begin{tabular}{|l|l|l|l|l|l|}
\hline \multicolumn{1}{|c|}{$\begin{array}{l}\text { Fatores de } \\
\text { Instabilidade }\end{array}$} & \multicolumn{1}{|c|}{$\begin{array}{c}\text { Área de } \\
\text { Estudo }\end{array}$} & $\begin{array}{l}\text { Áreas com } \\
\text { Escorrega- } \\
\text { mento }\end{array}$ & $\begin{array}{l}\text { Áreas sem } \\
\text { Escorrega- } \\
\text { mento }\end{array}$ & Ruito Baixo & Muito Alto \\
\hline litologia & $\begin{array}{l}\text { PSpX } \\
\text { AcMn }\end{array}$ & AcMn & $\begin{array}{l}\text { PSpX } \\
\text { AcMn }\end{array}$ & $\begin{array}{l}\text { OUTROS_L } \\
\text { PSpX }\end{array}$ & AcMn \\
\hline $\begin{array}{l}\text { precipitação } \\
\text { média } \\
\text { trimestre mais } \\
\text { chuvoso do }\end{array}$ & $\begin{array}{l}1.000 \mathrm{~mm}- \\
1.100 \mathrm{~mm}\end{array}$ & $\begin{array}{l}1.100 \mathrm{~mm}- \\
1.200 \mathrm{~mm}\end{array}$ & $\begin{array}{l}1.000 \mathrm{~mm}- \\
1.100 \mathrm{~mm}\end{array}$ & $\begin{array}{l}1.000 \mathrm{~mm}- \\
1.100 \mathrm{~mm}\end{array}$ & $\begin{array}{l}1.100 \mathrm{~mm}- \\
1.200 \mathrm{~mm}\end{array}$ \\
\hline $\begin{array}{l}\text { precipitação } \\
\text { média } \\
\text { anual total }\end{array}$ & $3.000 \mathrm{~mm}-$ & $3.200 \mathrm{~mm}-$ & $3.000 \mathrm{~mm}-$ & $3.000 \mathrm{~mm}-$ & $3.500 \mathrm{~mm}-$ \\
$3.100 \mathrm{~mm}$ & $3.300 \mathrm{~mm}$ & $3.100 \mathrm{~mm}$ & $3.100 \mathrm{~mm}$ & $3.600 \mathrm{~mm}$ \\
\hline
\end{tabular}

Fazendo-se um comparação entre os dados de áreas com escorregamento com os de áreas de risco de escorregamento muito alto, e de áreas sem escorregamento com os de áreas de risco de escorregamento muito baixo, contidos na Tabela 66, pode-se verificar os critérios de discriminação usados pela função discriminante. Pela não coincidência total entre as classes predominantes nas áreas comparadas, nota-se que essa função não baseou-se somente nessas classes para atribuir valores de probabilidade de risco de escorregamento. Baseou-se, também, nas classes onde a diferença entre as taxas de ocorrência de áreas com escorregamento e sem escorregamento foram expressivas. $\mathrm{Na}$ classe hipsométrica de $0 \mathrm{~m}$ a $100 \mathrm{~m}$ de altitude, só houve registro de áreas sem escorregamento e nela predominou áreas com risco de escorregamento muito baixo. Na classe clinográfica de $0^{\circ}$ a $7^{\circ}$, apesar de baixa, a taxa de áreas com escorregamento é superior a de áreas sem 
escorregamento, entretanto, nas duas classes clinográficas seguintes a essa $\left(7^{\circ}\right.$ a $17^{\circ}$, e $17^{\circ}$ a $\left.26^{\circ}\right)$, verifica-se maiores taxas de áreas sem escorregamento, e a acima dessas predominam áreas com escorregamento. Logo houve uma tendência de ocorrência de áreas com escorregamentos em altas declividades e de áreas sem escorregamentos em declividades inferiores, como se verifica nas classes predominantes de áreas de risco de escorregamento muito baixo e muito alto. As classes de orientação de vertente predominantes nas áreas comparadas, concordam quase que totalmente. Quanto a pedologia, as classes pedológicas $\mathrm{LVa}_{1}$ e $\mathrm{LVa}_{3}$ apresentaram as duas maiores taxas de ocorrência na área de estudo, nessa ordem, sendo que na primeira foi maior a taxa de áreas com escorregamentos e na segunda foi maior a taxa de áreas sem escorregamentos, o que concorda com suas predominâncias nas áreas com risco de escorregamento muito alto e muito baixo, respectivamente. Quanto à cobertura vegetal, as classes de vegetação do tipo arbórea baixa $(\mathrm{Ab})$ e herbácea a arbustiva $(\mathrm{H})$ apresentaram as duas maiores taxas de ocorrência na área de estudo, nessa ordem, sendo que na primeira foi maior a taxa de áreas com escorregamentos e na segunda foi maior a taxa de áreas sem escorregamentos, o que concorda com suas predominâncias nas áreas com risco de escorregamento muito alto e muito baixo, respectivamente. Quanto a morfologia nota-se a forte predominância da classe de vertentes retilíneas (VR) na área de estudo, tendo pouca relevância esse fator para a classificação do risco de escorregamento. Quanto à litologia, as classes litológicas de micaxistos (PSpX) e migmatitos estromatíticos (AcMn) apresentaram as duas maiores taxas de ocorrência na área de estudo, nessa ordem, sendo que na primeira foi maior a taxa de áreas sem escorregamento, e na segunda, foi maior a taxa de áreas com escorregamentos, o que concorda com suas predominâncias nas áreas com risco de escorregamento muito alto e muito baixo, respectivamente. Quanto a precipitação média do trimestre mais 
chuvoso e a precipitação média total anual, observa-se uma concordância entre as classes predominantes das áreas comparadas.

O perfil de cada classe de escorregamento em função das classes predominantes dos fatores de instabilidade é mostrado na Tabela 67.

Tabela 67. Classes predominantes dos fatores de instabilidade por classe de risco de escorregamento.

\begin{tabular}{|c|c|c|c|c|c|}
\hline & \multicolumn{5}{|c|}{ risco de escorregamento } \\
\hline $\begin{array}{l}\text { fatores de } \\
\text { instabilidade }\end{array}$ & muito baixo & baixo & médio & alto & muito alto \\
\hline hipsometria & $\begin{array}{l}0 \mathrm{~m}- \\
100 \mathrm{~m}\end{array}$ & $\begin{array}{l}100 \mathrm{~m}- \\
300 \mathrm{~m}\end{array}$ & $\begin{array}{l}100 \mathrm{~m}- \\
300 \mathrm{~m}\end{array}$ & $\begin{array}{l}300 \mathrm{~m}- \\
500 \mathrm{~m}\end{array}$ & $\begin{array}{l}500 \mathrm{~m}- \\
700 \mathrm{~m}\end{array}$ \\
\hline clinometria & $0^{\circ}-7^{\circ}$ & $17^{\circ}-26^{\circ}$ & $17^{0}-26^{0}$ & $26^{\circ}-36^{\circ}$ & $26^{\circ}-36^{\circ}$ \\
\hline $\begin{array}{l}\text { exposição de } \\
\text { vertentes }\end{array}$ & SE & NO & $S$ & $S$ & $S E$ \\
\hline pedologia & $L V a_{3}$ & $\mathrm{LVa}_{1}$ & $L \mathrm{Va}_{1}$ & $L \mathrm{La}_{1}$ & $\mathrm{LVa}_{1}$ \\
\hline cobertura vegetal & $\mathrm{H}$ & $\overline{A b}$ & $\mathrm{Ab}$ & $\mathrm{Ab}$ & $\overline{A b}$ \\
\hline morfologia & VR & VR & VR & VR & VR \\
\hline litologia & OUTROS_L & PSpX & PSpX & AcMn & AcMn \\
\hline $\begin{array}{l}\text { precipitação média do } \\
\text { trimestre mais } \\
\text { chuvoso }\end{array}$ & $\begin{array}{l}1.000 \mathrm{~mm}- \\
1.100 \mathrm{~mm}\end{array}$ & $\begin{array}{l}1.100 \mathrm{~mm}- \\
1.100 \mathrm{~mm}\end{array}$ & $\begin{array}{l}1.000 \mathrm{~mm}- \\
1.100 \mathrm{~mm}\end{array}$ & $\begin{array}{l}1.100 \mathrm{~mm}- \\
1.200 \mathrm{~mm}\end{array}$ & $\begin{array}{l}1.100 \mathrm{~mm}- \\
1.200 \mathrm{~mm}\end{array}$ \\
\hline $\begin{array}{l}\text { precipitação média } \\
\text { total anual }\end{array}$ & $\begin{array}{l}3.000 \mathrm{~mm}- \\
3.100 \mathrm{~mm}\end{array}$ & $\begin{array}{l}3.000 \mathrm{~mm}- \\
3.100 \mathrm{~mm}\end{array}$ & $\begin{array}{l}3.200 \mathrm{~mm}- \\
3.300 \mathrm{~mm}\end{array}$ & $\begin{array}{l}3.200 \mathrm{~mm}- \\
3.300 \mathrm{~mm}\end{array}$ & $\begin{array}{l}3.500 \mathrm{~mm}- \\
3.600 \mathrm{~mm}\end{array}$ \\
\hline
\end{tabular}

Pelos dados da Tabela 67, ressalta-se as áreas com risco de escorregamento alto e muito alto que ocorreram em vertentes da média e alta encosta ( $300 \mathrm{~m}$ a $700 \mathrm{~m}$ ), com altas declividades $\left(26^{\circ}\right.$ a $\left.36^{\circ}\right)$ e exposição sul (S) e sudeste (SE), em solos do tipo latossolo vermelho-amarelo $\left(L V a_{1}\right)$, cobertura vegetal de porte arbóreo baixo $(A b)$, vertentes retilíneas (VR), litologia do tipo migmatitos estromatíticos (AcMn), em áreas onde a precipitação média do trimestre mais chuvoso esteve entre $1.100 \mathrm{~mm}$ e 1.200 
$\mathrm{mm}$ e a precipitação média anual entre $3.200 \mathrm{~mm}$ e $3.600 \mathrm{~mm}$. Por outro lado, as áreas com risco de escorregamento muito baixo, que podem ser consideradas estáveis, ocorreram em vertentes da baixa encosta ( $0 \mathrm{~m}-100$ $m)$, com baixas declividades $\left(0^{\circ}-7^{\circ}\right)$ e exposição sudeste (SE), em solos do tipo latossolo vermelho-amarelo $\left(\mathrm{LVa}_{3}\right)$, cobertura vegetal de porte herbáceo a arbustivo $(H)$, vertentes retilíneas (VR), litologia do tipo micaxistos (PSpX), em áreas onde a precipitação média do trimestre mais chuvoso esteve entre 1.000 $\mathrm{mm}$ e $1.100 \mathrm{~mm}$ e a precipitação média anual entre $3.000 \mathrm{~mm}$ e $3.100 \mathrm{~mm}$. 


\section{CONCLUSÕES}

A conversão de mapas do formato analógico para o digital mostrou-se eficiente, tanto através da digitalização em mesa digitalizadora como através de scanner, ambos apresentando erros quadráticos médios aceitáveis.

O uso do sistema de informações geográficas, permitiu a obtenção de dados precisos e com rapidez, apresentando os resultados na forma gráfica e em tabelas que puderam ser exportados para outros softwares, permitindo seu tratamento posterior.

O modelo estatístico de análise multivariada, a análise discriminante linear, apresentou uma eficácia de $82,41 \%$ na classificação das áreas com escorregamento e sem escorregamento.

Os critérios de classificação de risco de escorregamento, da função discriminante, concordam com a ocorrência dos fatores de instabilidade predominantes na área de estudo, e nas áreas com e sem escorregamento, indicando uma boa representação do risco de escorregamento através da mesma.

Quanto à contribuição de cada fator de instabilidade, presente na função discriminante, pode-se destacar, como característica de maior relevância, a clinografia; a precipitação média do trimestre mais chuvoso; a pedologia como o componente físico, seguida da litologia e da cobertura vegetal, ficando morfologia com o menor peso. 
As áreas com risco de escorregamento muito baixo compreenderam $44,4 \%$ da área de estudo, enquanto áreas com risco de escorregamento alto e muito alto, juntas, compreenderam $25,6 \%$ da área de estudo $(2.740,9 \mathrm{ha})$.

Áreas com risco de escorregamento alto e muito alto ocorreram predominantemente em vertentes da média e alta encosta (300 m a $700 \mathrm{~m}$ ), com altas declividades $\left(26^{\circ}\right.$ a $\left.36^{\circ}\right)$ e exposição sul (S) e sudeste (SE), em solos do tipo latossolo vermelho-amarelo $\left(\operatorname{LVa}_{1}\right)$, cobertura vegetal de porte arbóreo baixo $(A b)$, vertentes retilíneas (VR), litologia do tipo migmatitos estromatíticos ( $A c M n)$, em áreas onde a precipitação média do trimestre mais chuvoso esteve entre $1.100 \mathrm{~mm}$ e $1.200 \mathrm{~mm}$ e a precipitação média anual entre $3.200 \mathrm{~mm}$ e $3.600 \mathrm{~mm}$. Áreas com risco de escorregamento muito baixo ocorreram predominantemente em vertentes da baixa encosta $(0 \mathrm{~m}-100 \mathrm{~m})$, com baixas declividades $\left(0^{\circ}-7^{\circ}\right)$ e exposição sudeste (SE), em solos do tipo latossolo vermelho-amarelo $\left(\mathrm{LVa}_{3}\right)$, cobertura vegetal de porte herbáceo a arbustivo $(H)$, vertentes retilíneas (VR), litologia do tipo micaxistos (PSpX), em áreas onde a precipitação média do trimestre mais chuvoso esteve entre 1.000 $\mathrm{mm}$ e $1.100 \mathrm{~mm}$ e a precipitação média anual entre $3.000 \mathrm{~mm}$ e $3.100 \mathrm{~mm}$.

As áreas classificadas com risco de escorregamento muito alto, devem ser alvos de estudos mais detalhados, em escalas menores.

Escorregamentos são eventos catastróficos passíveis de serem mapeados quanto ao seu risco de ocorrência.

A metodologia desenvolvida pode ser aplicada em outras áreas, onde as informações disponiveis sejam as definidas por este trabalho. O mapa de risco de escorregamento produzido pode ser utilizado como base para o planejamento do uso do solo da área de estudo e de medidas preventivas à ocorrência de escorregamentos. Devido a sua simplicidade, este mapa é de fácil compreensão, mesmo para um técnico não especializado. 
125

ANEXOS 
ANEXO A: Mapa Hipsométrico da Região de Cubatão, SP 


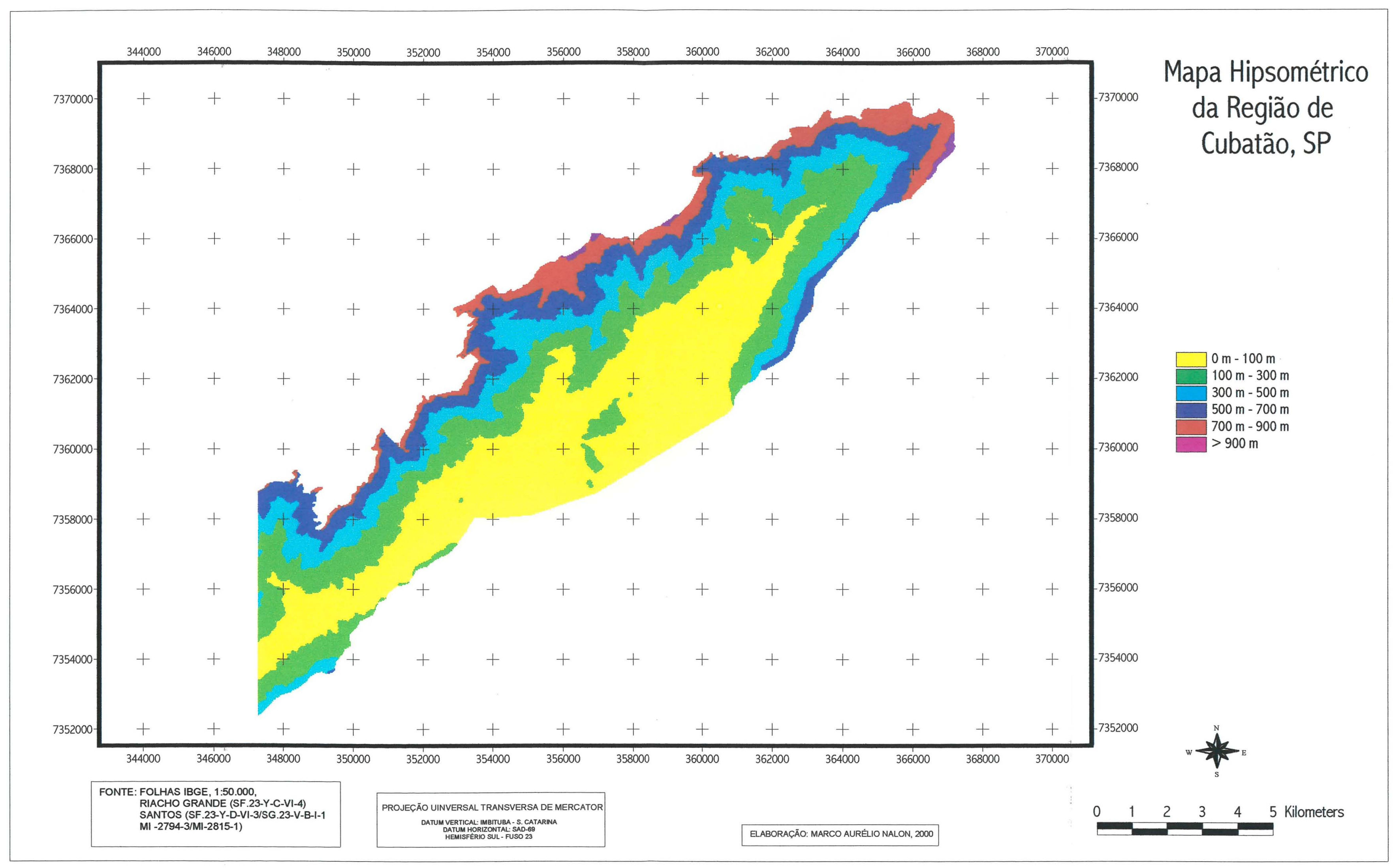


ANEXO B: Mapa Clinográfico da Região de Cubatão, SP 


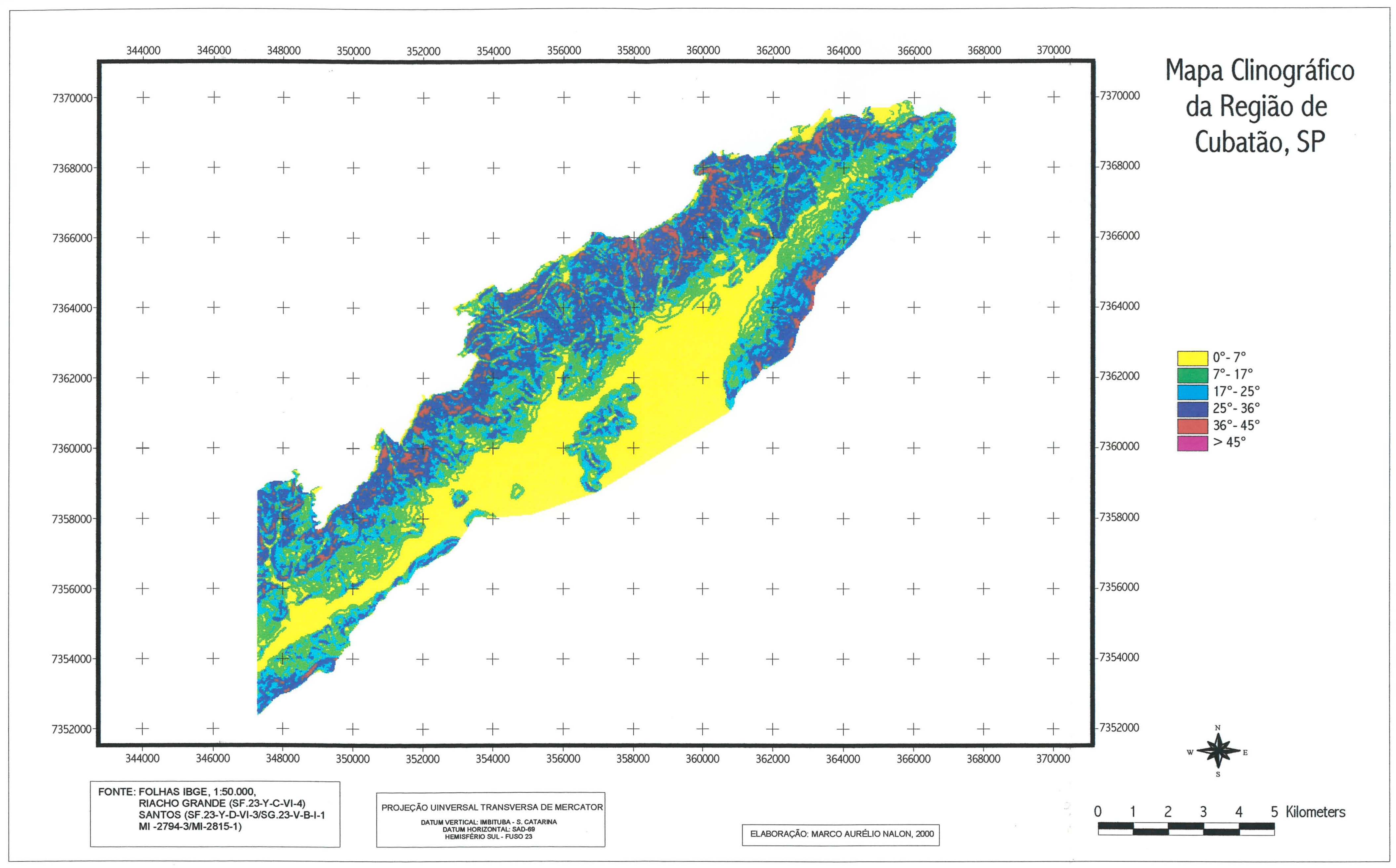


ANEXO C: Mapa de Exposição de Vertentes da Região de Cubatão, SP 


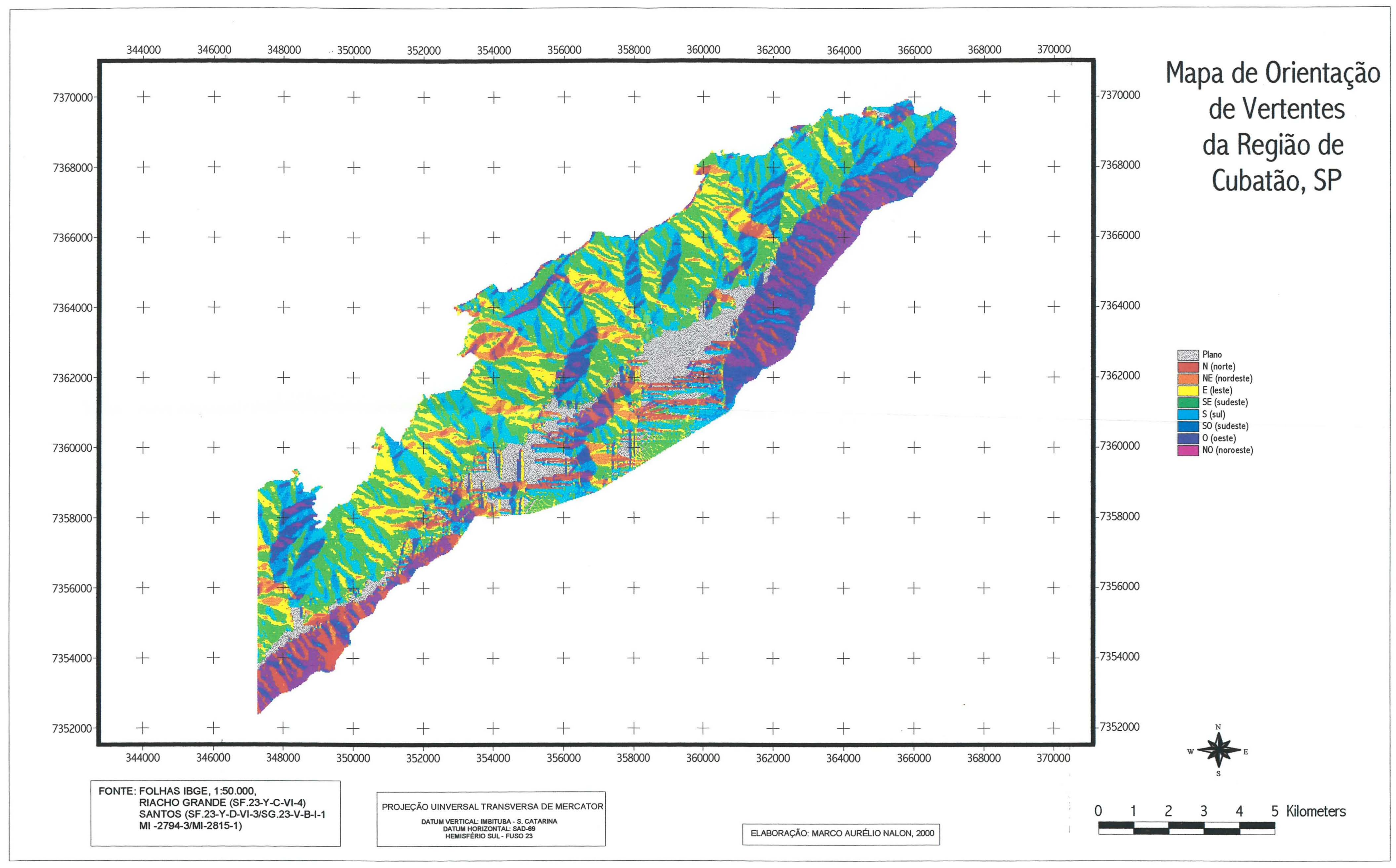


ANEXO D: Mapa Pedológico da Região de Cubatão, SP (ROSSI \& PFEIFER, 1991) 


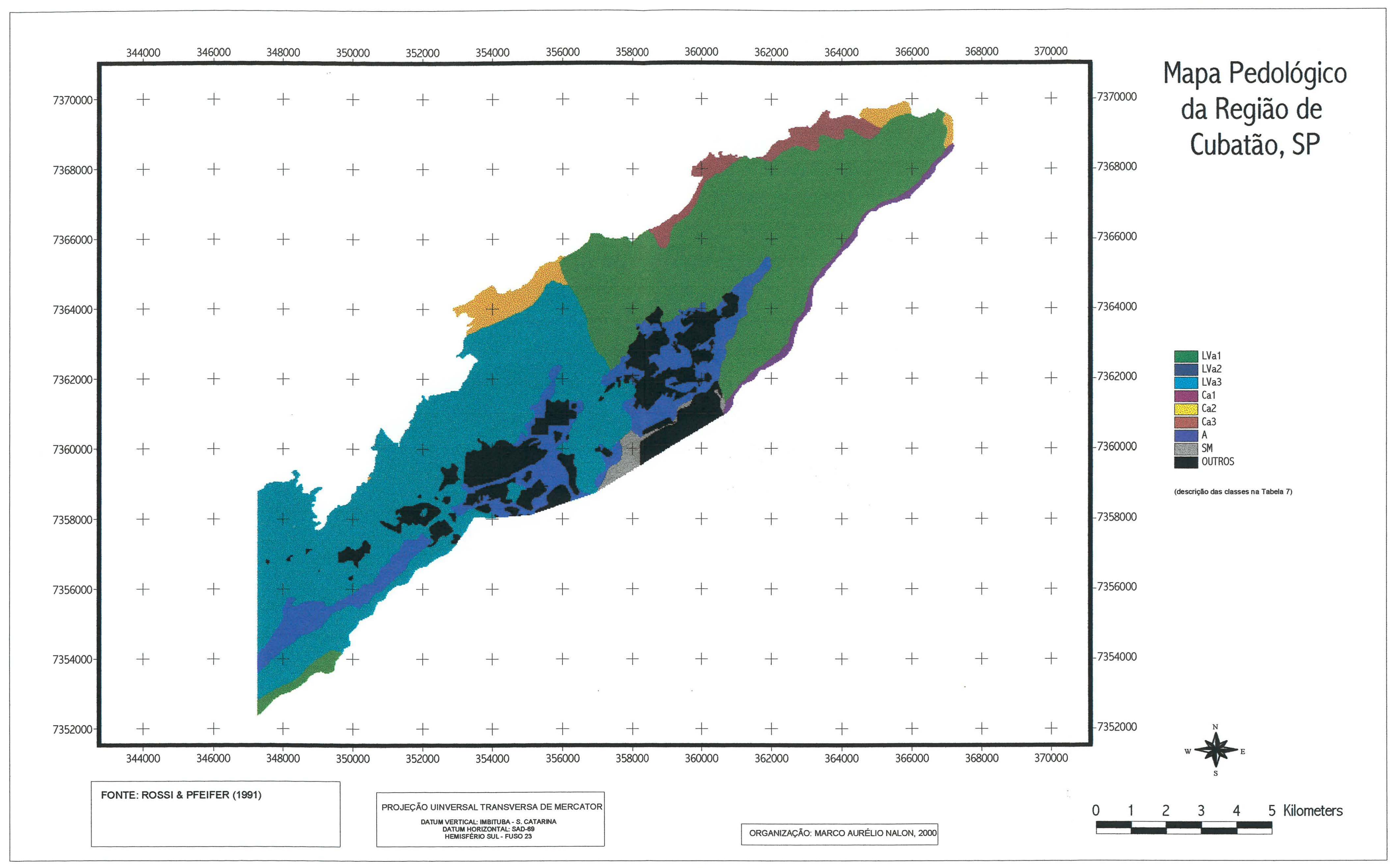


ANEXO E: Mapa de Cobertura Vegetal da Região de Cubatão, SP (MATTOS \& MATSUKUMA, 1990) 


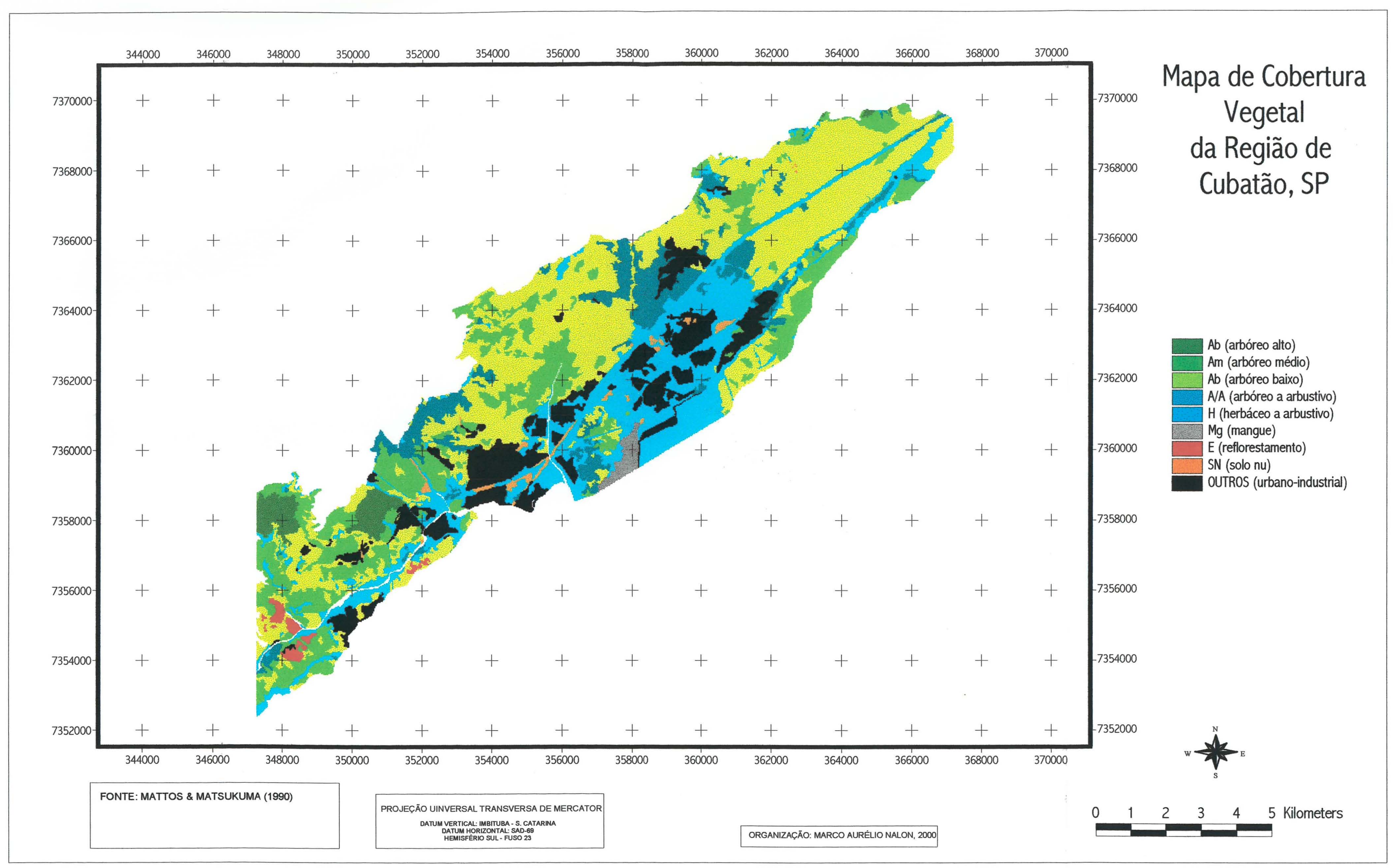


ANEXO F: Mapa Morfológico da Região de Cubatão, SP (CETESB, 1991) 


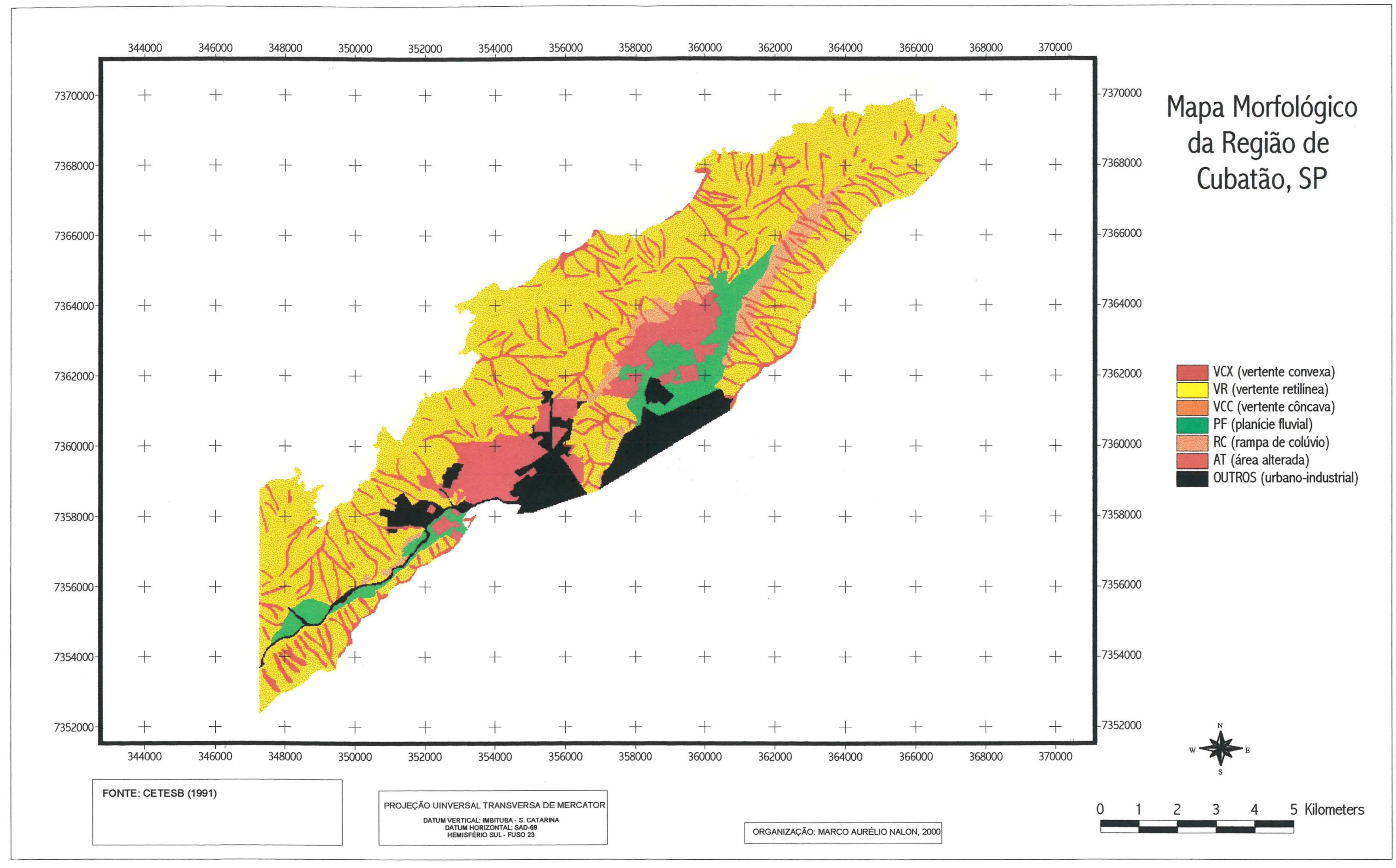


ANEXO G: Mapa Litológico da Região de Cubatão, SP (CETESB, 1991) 


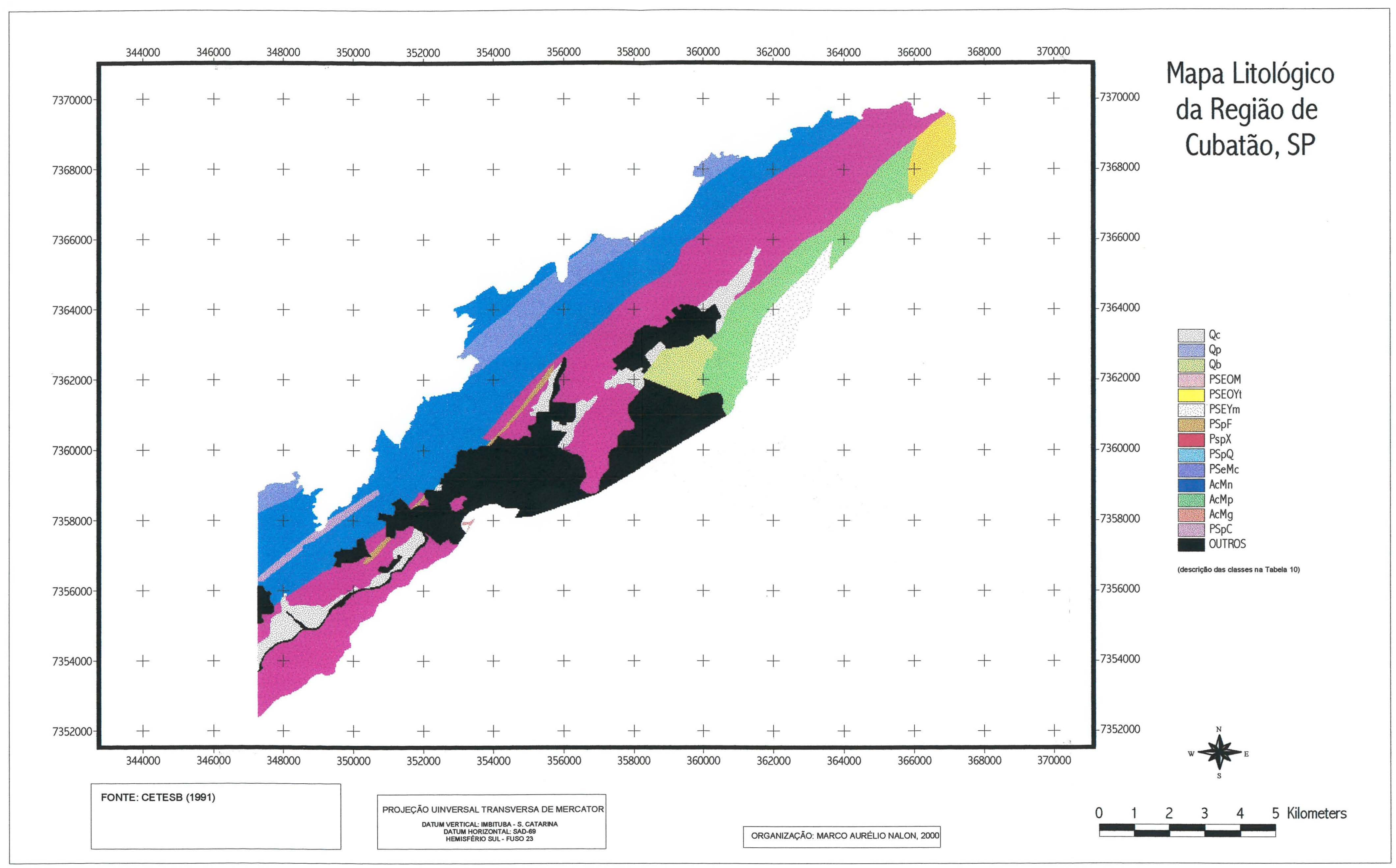


ANEXO H: Mapa da Precipitação Média do Trimestre mais Chuvoso da Região de Cubatão, SP (IPT, 1985) 


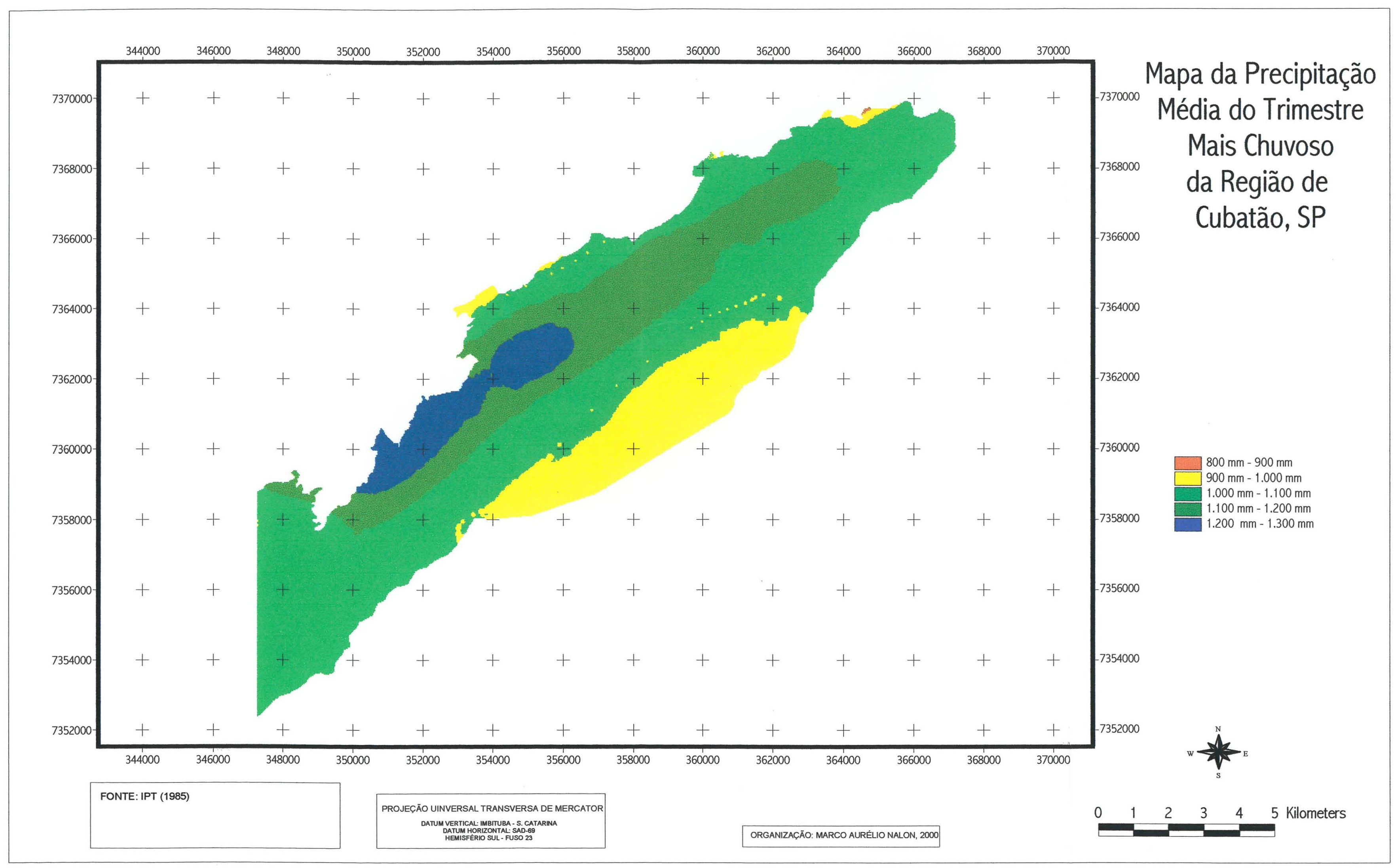


ANEXO I: Mapa da Precipitação Média Total Anual da Região de Cubatão, SP (IPT, 1985) 


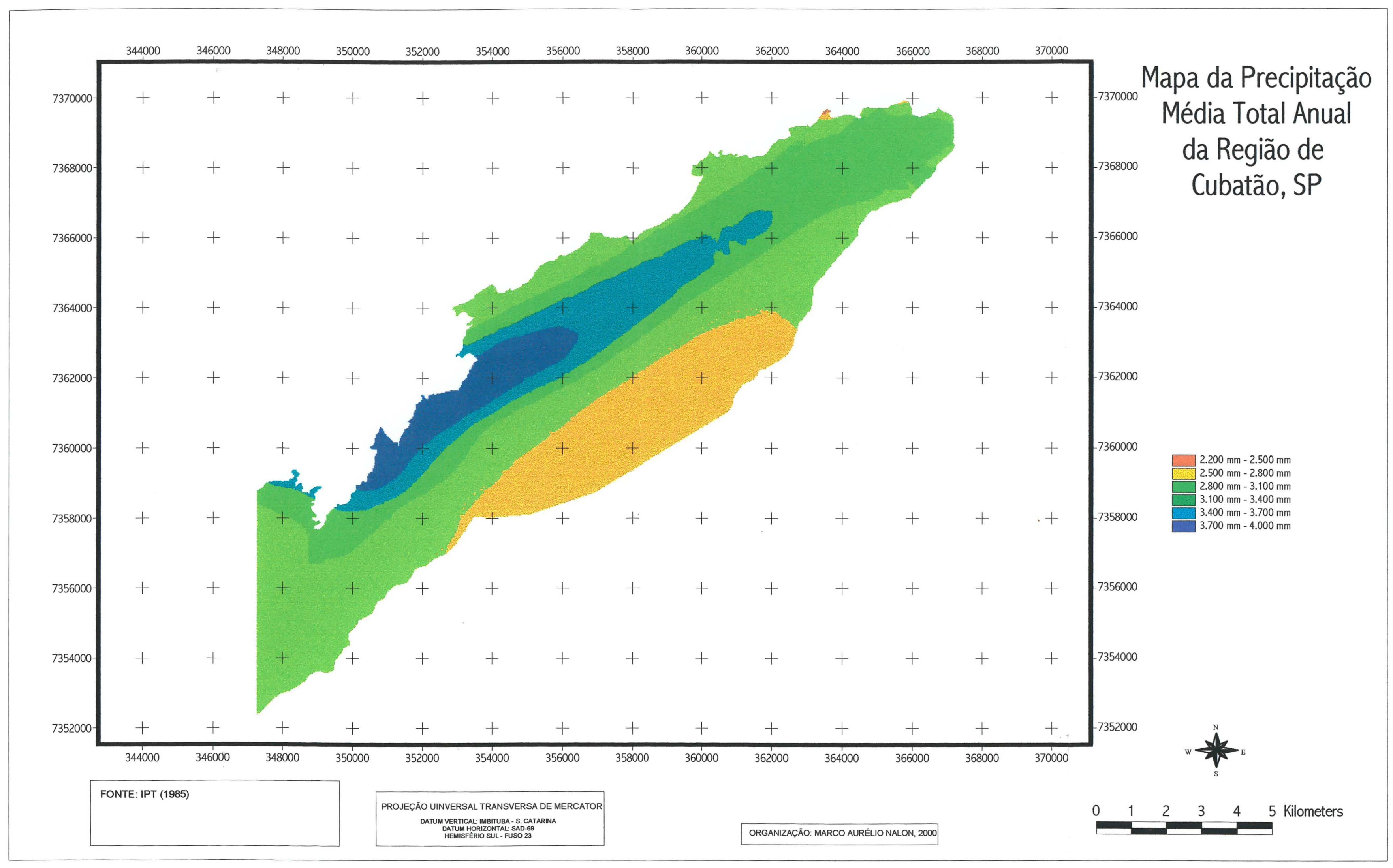


ANEXO J: Mapa das Áreas com Escorregamento da Região de Cubatão, SP (CETESB, 1991) 


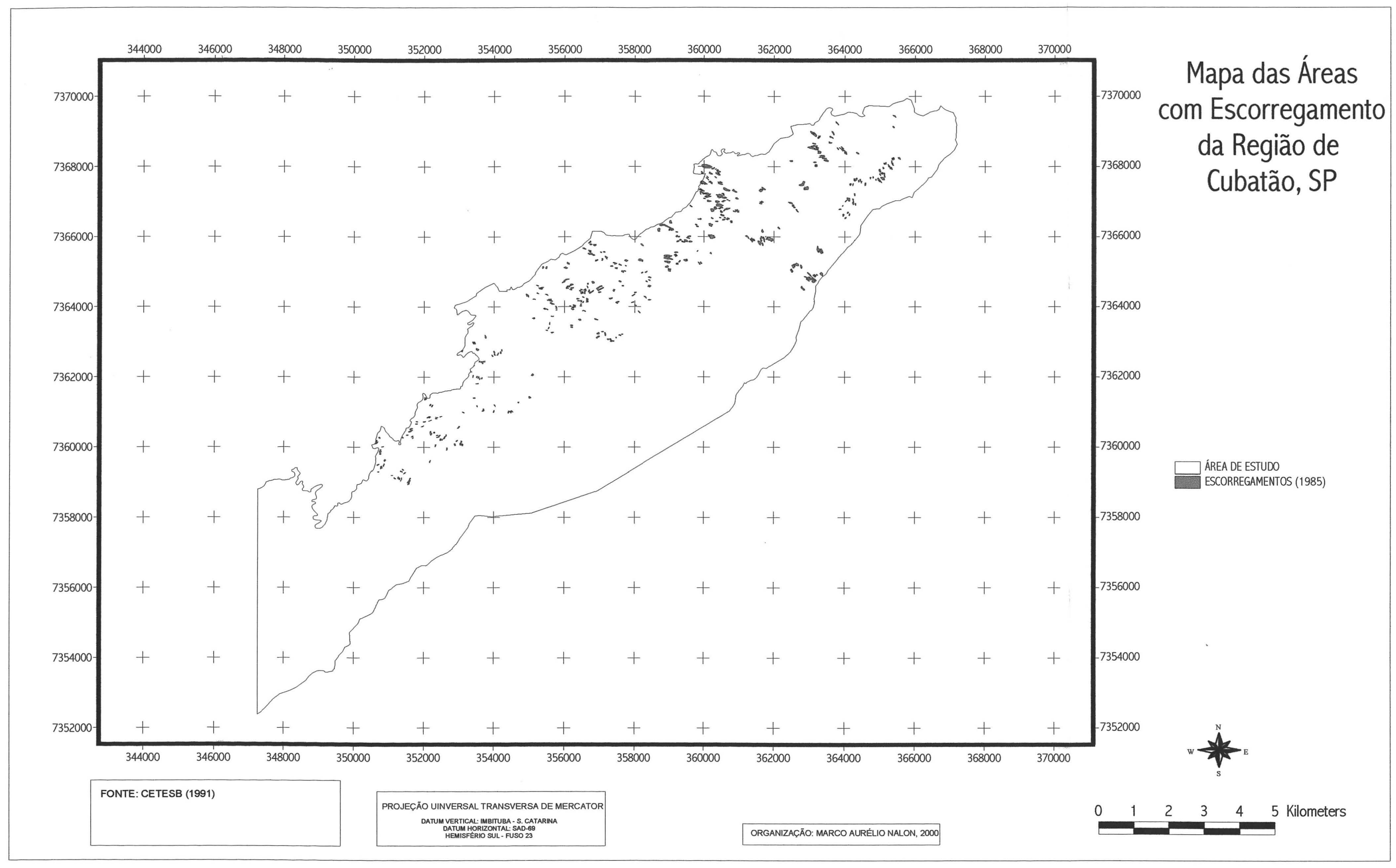


ANEXO K: Mapa das Áreas sem Escorregamento da Região de Cubatão, SP 


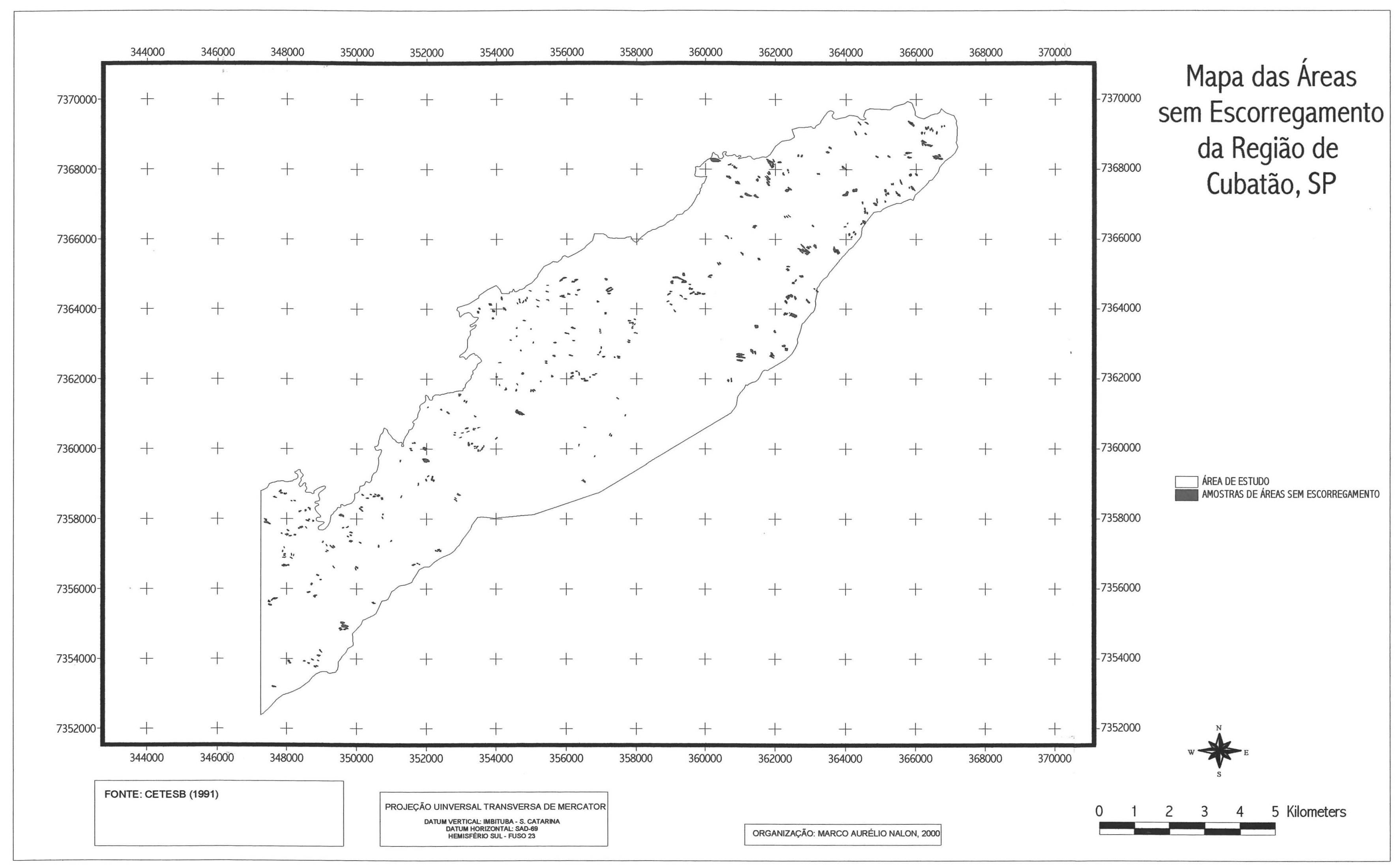


ANEXO L: Mapa de Risco de Escorregamento da Região de Cubatão, SP 


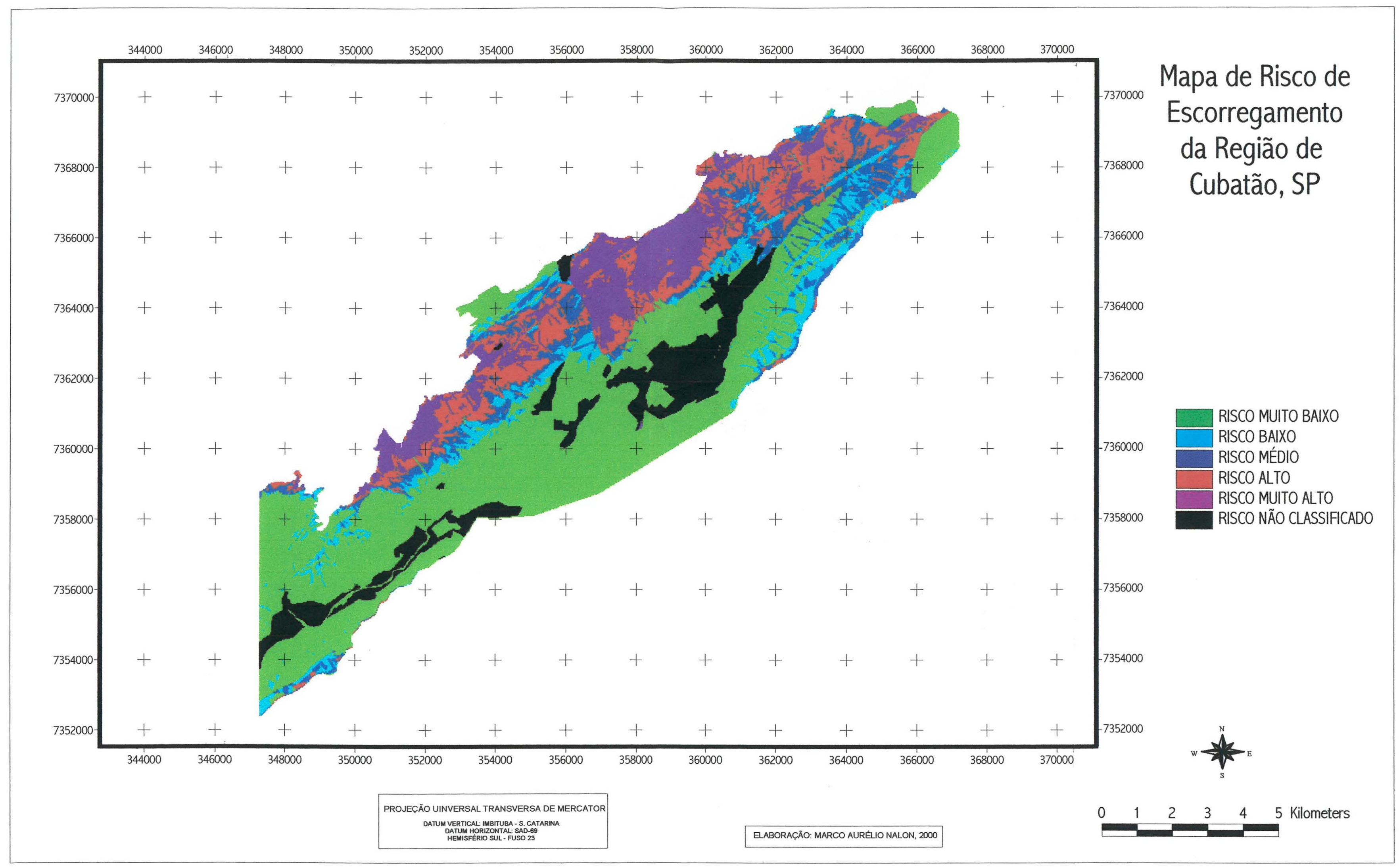




\section{REFERÊNCIAS BIBLIOGRÁFICAS}

AGUIAR, M.B.; KRELING, P.R. Elaboração gráfica de carta de classes de declividade de vertentes. Revista do Departamento de Geografia, F.F.L.C.H./Universidade de São Paulo, São Paulo. n.3, p.09-116, 1984.

ALVES, D.S. Sistemas de Informação Geográfica. In: SIMPÓSIO BRASILEIRO DE GEOPROCESSAMENTO, São Paulo, 1990. São Paulo: POLI/Universidade de São Paulo, 1990. p.66-78.

ALVES, D.S.; PAIVA, J.A.C. Sistemas de informações geográficas para o gerenciamento costeiro. In: SIMPÓSIO BRASILEIRO DE GEOPROCESSAMENTO, São Paulo, 1990. São Paulo: POLI/USP, 1990. p.290-295.

ANBALAGAN, R.; SINGH B. Landslide hazard and risk assessment mapping of mountainous terrains - a case study from Kumaun Himalya, India. Engineering Geology, v.43, p.237-246, 1996.

ARGENTO, M.S.F.; MARQUES, J.S. Aplicações de sistemas de informações em projetos de gerenciamento ambiental. Geociências, n.7, p.21-42, 1988. 
AUGUSTO FILHO, O. Cartas de risco de escorregamentos: uma proposta metodológica e sua aplicação no município de Ilhabela, SP. São Paulo, 1994. 168p. Dissertação (M.S.) - Escola Politécnica, Universidade de São Paulo.

BACCARO, C.A.D. Os processos de movimentos de massa da Serra do Mar em Cubatão (São Paulo). Boletim de Geografia Teorética, v.15, n.29-30, p.312-317, 1985.

BOCCO, G. 1991. Integration of GIS and remote sensing in land use and erosion studies. Remote sensing and geographical information systems for resource management in developing countries. Remote Sensing Vol. 1. Kluwer Academic Pubs. p.477-490.

BRÄNDLI, M. Hierarchical models for the definition and extraction of terrain features.. In: BURROUGH, P.A., FRANK, A.U. (Ed.) Geographic objects with indeterminate boundaries. London:Taylor \& Francis, 1996. cap.17, p. 257-270.

BURROUGH, P.A. Natural objects with inderminate boundaries. In: : BURROUGH, P.A., FRANK, A.U. (Ed.) Geographic objects with indeterminate boundaries. London:Taylor \& Francis, 1996. cap.1, p.3-28.

CAMARGO, J.G.C. et al. Estudos fitogeográficos e ecológicos da bacia hidrográfica paulista do rio Ribeira. São Paulo: USP, 1972. 30p. (biografia, 5). 
CARNEIRO, C.M.R. Curso de sensoriamento remoto. Brasília: IBDF/PNUD/FAO, 1980. 198p. (PNUD/FAO/IBDF/BRA778/008; Série Técnica, 6).

CARRARA, A.; CARNINATLI, M.D.R.; GUZZETTI, F.; PASQUI, V.; REICHENBACH, P. GIS techniques and statistical-models in evaluating landslide hazard. In: Earth surface processes and landforms. Sussex: John Wiley \& Sons LTD. v.16, n.5, p.427-445, 1991.

CASTRO, J.F.M. Aplicação de um sistema de informação geográfica na temática da morfodinâmica: o exemplo do estudo das bacia do Rio Mogi Cubatão/SP. São Paulo, 1993. 216p. Dissertação (M. S.) - F.F.L.C.H. Universidade de São Paulo.

COMPANHIA DE TECNOLOGIA DE SANEAMENTO AMBIENTAL, CETESB. Mapeamento do Uso do solo, das cicatrizes de escorregamentos e caracterização preliminar da estrutura da cobertura vegetal da Serra do Mar, em Cubatão - SP. São Paulo: CETESB, 1987. 85p. (Relatório Técnico).

CETESB. Avaliação do estado de degradação dos ecossistemas da Baixada Santista - SP. São Paulo: CETESB, 1991. 32p. (Relatório Técnico).

COLANGELO, A.C. Os mecanismos de compensação e o equilibrio de forças na dinâmica dos materiais de vertente. Revista do Departamento de Geografia, n.9, p.13-20, 1995.

COLANGELO, A.C. Os modelos de feições mínimas, ou das unidades elementares de relevo: um suporte cartográfico para mapeamentos 
geoecológicos. Revista do Departamento de Geografia,. USP-FFLCH. São Paulo. p.29-40. 1996.

COSTA, T.C.C.; SOUZA, M.G.; BRITES, R.S. Delimitação e caracterização de áreas de preservação permanente por meio de um Sistema de Informações Geográficas (SIG). Revista da Árvore, v.20, n.1, p.129-135, 1996.

CRUZ, O. Evolução de vertentes nas escarpas da Serra do Mar em Caraguatatuba - SP. Anais Acad. Brasil. Ciências, v.47, p479-482, 1975. Suplemento.

DE BIASI, M. Carta de declividade de vertentes: confecção e utilização. Geomorfologia, n. 21, 1970.

DE BIASI, M.; SIMIELLI, M.E.R.; LUCCHESI, E.S. \& OMAKI, N. E. Cartas de orientação de vertentes: confecção e utilização. Cartografia, n. 4, 1977.

DE BIASI, M. A carta clinográfica. Revista do Departamento de Geografia, n.6, p.45-60, 1992.

De PLOEY, J.; CRUZ, O. Landslides in the Serra do Mar, Brasil. Catena, v.6, n.2, p.11-122, 1979.

DIKAU, R; CAVALLIN, A.; JÄGER, S. Dababases and GIS for landslide research in Europe. Geomorphology, v.15, p.227-239, 1996.

DOMINGUES, E. N. Estudo de processos geomorfológicos do escoamento fluvial e evolução de vertentes na Serra do Cubatão, Serra do Mar - SP. 
São Paulo, 1983. 153p. Dissertação (M. S.) - F.F.L.C.H., Universidade de São Paulo.

EAST, E. J.; SIMONETT, S. A. Fundamental of images interpretation. In: AMERICAN SOCIETY OF PHOTGRAMMETRY. Manual of Remote Senging. Fells Church:, 1975. v.2, p.869-1076.

FRANKLIN, S.E.; BROWER, W.W.; GHITTER, G. Discrimination of adelgiddamage on single balsam fir trees with aerial remote-sensing data. International Journal of Remote Sensing. v.16, n.15, p.2779-2794, 1995.

GAMA, C. D. Cartografia digital e sua utilização em microcomputador gráfico interativo. Geociências, n.7, p.95-114, 1988.

GOES, M.H.B. Áreas de riscos de desmoronamentos/deslizamentos: uma aplicação de geoprocessamento de dados. Geociências, n. , p.107-124, 1990. Número especial.

GUERRA, A.J.T.; BOTELHO, R.G.M. Erosão dos solos. In: CUNHA, S.B; GUERRA, A.J.T. (Org.) Geomorfologia do Brasil. Bertrand Brasil, 1998. cap. 5 , p.181-227.

GUIDICINI, G. \& IWASA, O. Y. 1976. Ensaio de Correlação entre Pluviosidade e Escorregamentos no Meio Tropical Úmido. São Paulo. Instituto de Pesquisas Tecnológicas. 48p. (publicação, 1080).

HUECK, K. As florestas da América do Sul, ecologia, composição e importância econômica. Trad. de Hans Ruchardt. São Paulo: Polígono, 1972, 466p. 
INSTITUTO DE PESQUISAS TECNOLÓGICAS DO ESTADO DE SÃO PAULO, IPT. Programa Serra do Mar - levantamentos básicos nas folhas de Santos e Riacho Grande, Estado de São Paulo. Relatório $n^{\circ}$ 23.394. vol.5. São Paulo: IPT, 1985 v.5 (Relatório, 23.394).

IPT. Programa Serra do Mar - levantamentos básicos nas folhas de Santos e Riacho Grande, Estado de São Paulo. São Paulo: IPT, 1987 (Relatório)

KRONKA, F.J.N.; MATSUKUMA, C.K.; NALON, M.A.; DEL CALI, I.H.; ROSSI, M.; MATTOS, I.F.A.; SHIN-IKE, M.S.; PONTINHAS, A.A.S. 1993. Inventário Florestal do Estado de São Paulo.. São Paulo: Instituto Florestal, 1993. $199 p$.

LIMA, E.R.V;; KUX, H.J.H.; SAUSEN, T.M. Sistema de informações Geográficas e técnicas de sensoriamento remoto na elaboração de mapa de riscos de erosão no sertão da Paraíba. Revista Brasileira de Ciências do Solo, v.16, p.257-263, 1992.

LO, C.P.; SHIPMAN, R.L. A GIS approach to land-use change dynamics detection. Photogrammetric Engineering \& Remoto Sensing, v.56, n.11, p.1483-1491, 1990.

LUEDER, D.R. Aerial photographics interpretation principles and applications. New York. Mac Graw-Hill Book Co. Inc., 1959. 462p.

MACLEAN, A.L.; REED, D.D.; MROZ, G.D.; LYON, G.W.; EDISON, T. Using GIS to estimate forest resource change. A case study in northern Michigan. Journal of Forestry, p.22-25, 1992. 
MANTOVANI, F; SOETERS, R.; VAN WESTEN, CJ. Remote sensing techniques for landslide studies and hazard zonation in Europe. Geomorphology, v.15, p.213-225, 1996.

MATTOS, I.F.A.; MATSUKUMA, C.K. Mapeamento evolutivo da vegetação da Serra do Mar, Cubatão - SP. In: CONGRESSO FLORESTAL BRASILEIRO, 6., Campos do Jordão, 1990. Anais. São Paulo: Sociedade Brasileira de Silvicultura, Sociedade Brasileira de Engenheiros Florestais, novembro/1990. p.330-343.

MILES, S.B.; HO, C.L. Rigorous landslide hazard zonation using Newmark's method and stochastic ground motion simulation. Soil Dynamics and Earthquake Engineering, v.18, p.305-323, 1999.

MIRANDA, E.E. Geoprocessamento em análise ambiental: A experiência da EMBRAPA. In: SIMPÓSIO BRASILEIRO DE GEOPROCESSAMENTO, São Paulo, 1990. Anais. São Paulo: Escola Politécnica/USP, 1990. p.198-203.

MORETTI, E.; KOFFLER, N.F. \& TEIXEIRA, A.L.A. Técnicas digitais para mapeamento da declividade e orientação de vertentes baseadas no uso de sistemas de informação geográfica. Boletim de Geografia Teorética, v.19, n. $37-38$, p.29-52, 1989.

NALON, M.A.; VELLARDI, A.C.V. 1993. Estudo do balanço hídrico nas escarpas da Serra do Mar, região de Cubatão, SP. Revista do Instituto Florestal, v.5, n.1, p.39-58, 1993. 
PERALTA, E. Elaboração do modelo digital para determinar áreas de riscos de deslizamentos utilizando o SAGA. In: SIMPÓSIO BRASILEIRO DE GEOPROCESSAMENTO, São Paulo, 1990. Anais. São Paulo: POLI/USP, 1990, p.248-261

POLEMIO, M.; SDAO F. The role of rainfall in the landslide hazard: the case of the Avigliano urban area (Southern Apennines, Italy). Engineering Geology, v.53, p.297-309, 1999.

PROGRAMA SERRA DO MAR. CONVÊNIO SAA-IF/PETROBRÁS. Projeto "Estudo Hidrodinâmico na Floresta Latifoliada das Encostas da Serra do Mar, na Região de Cubatão - SP." São Paulo: Instituto Florestal, 1987. 58p. (Relatório, 1).

QUEIROZ NETO, J.P de; KUPPER, A. Os solos. In: A Baixada Santista; aspectos geográficos: bases físicas. São Paulo. EDUSP, 1965, v.1, p.6792.

RIZZINI, C.T. Tratado de fitogeografia do Brasil: aspectos sociológicos e florísticos. São Paulo: Hucitec/EDUSP. 1979, 374p.

ROSA, R. Uso de sig's para o zoneamento: uma abordagem metodológica. São Paulo, 1995. 225p. Tese (Doutorado) - F.F.L.C.H., Universidade de São Paulo.

ROSSI, M.; PFEIFER, R.M. Pedologia do Parque Estadual da Serra do Mar- I. Levantamento de reconhecimento dos solos. Revista do Instituto Florestal, v.3, n.1, p.1-44, 1991. 
ROSSI, M.; PFEIFER, R.M.; NALON, M.A. Pedologia do Parque Estadual da Serra do Mar III. Fotointerpretação de bacias hidrográficas. Revista do Instituto Florestal, v.3, n.1, p.67-93, 1991.

SKIDMORE, A.K.; RYAN, P.J.; DAWES, W.; SHORT, D.; O'LOUGHLIN, E. Int. J. Geographical Information Systems, v.5, n.4, p.431-445, 1991.

SMITH, L.R. et al. Determinants of early versus late cardiac death in patients undergoing coronary-artery bypass graft-surgery. In: Circulation. Dallas: Amer Heart Assoc. v.84, n.5, p.245-253, 1991. (Suppl. S).

SOUZA, W. Planejamento da rede viária e zoneamento em unidades de conservação, empregando um Sistema de Informações Geográficas. Viçosa, 1990. 89p. Tese ("Magister Scientiae") - Universidade Federal de Viçosa.

SPURR, S.N. Photogrammetry and photointerpretation. New York: Ronald Press Co., 1969. 772p.

TEIXEIRA, A.L.A.; PROCHNOW, M.C.R.; SUAREZ, R. \& CARDOZO, S. Determinação das áreas de risco à erosão na Bacia do Córrego Monjolo Grande (SP), através do uso de um SIG. In: SIMPÓSIO BRASILEIRO DE GEOPROCESSAMENTO, SÃO PAULO, 1990. Anais. São Paulo: POLI/USP, 1990. p.300-307.

TEIXEIRA, A.L.A. \& GERARDI, L.H.O. Construção automática de cartas de exposição de vertentes. Geociências, v.11, n.1, p.113-132, 1992. 
TEIXEIRA, A.L.A.; MORETTI, E \& CHRISTOFOLETTI, A. Introdução aos Sistemas de Informação Geográfica., Rio Claro: Ed. do Autor, 1992. 80p.

TEUBNER JUNIOR, F.J. Utilização da tecnologia de sistemas de informação geográfica para a definição de zoneamentos ambientais costeiros: um estudo de caso para a região da grande Vitória. São Paulo: Escola Politécnica/USP, 1993. 174p.

TOMIDA, Y. Master plan for SABO works in the study area. In: SABO and river improvement works in Japan and master plan on the disaster prevention in Serra do Mar, Cubatão region, state of São Paulo. São Paulo, 1990. p. 62-74. (Relatório).

TROPPMAIR, H. \& FERREIRA, M.E.M.C. Cobertura vegetal, poluição aérea e deslizamentos na Serra do Mar. Geografia, v.12, n.23, p.117-129, 1987.

TURRINI, M.C.; VISINTAINER, P. Proposal of a method to define areas of landslide hazard and application to na area of Dolomites, Italy. Engineering Geology, v.50, p.255-265, 1998.

WESTMORELAND, S.; STOW, D.A. 1992. Category identification of changed land-use polygons in an ontegrated image processing/geographic information system. Photogrammetric Engineering \& Remote Sensing, v. 58, n.11, p.1593-1599, 1992 